2016-11-25

Ocean sprawl: challenges and opportunities for biodiversity

management in a changing world

Firth, Louise

http://hdl.handle.net/10026.1/8025

\title{
$10.1201 / 9781315368597$
}

Oceanography and Marine Biology: an annual review Aberdeen University Press

All content in PEARL is protected by copyright law. Author manuscripts are made available in accordance with publisher policies. Please cite only the published version using the details provided on the item record or document. In the absence of an open licence (e.g. Creative Commons), permissions for further reuse of content should be sought from the publisher or author. 
Oceanography and Marine Biology: An Annual Review, 2016, 54, 189-262

(C) R. N. Hughes. D. J. Hughes, I. P. Smith, and A. C. Dale, Editors

Taylor \& Francis

\title{
OCEAN SPRAWL: CHALLENGES AND OPPORTUNITIES FOR BIODIVERSITY MANAGEMENT IN A CHANGING WORLD
}

\author{
LOUISE B. FIRTH ${ }^{1}$, ANTONY M. KNIGHTS ${ }^{1}$, DANIELLE BRIDGER ${ }^{2}$, \\ ALISON J. EVANS ${ }^{3}$, NOVA MIESZKOWSKA ${ }^{4}$, PIPPA MOORE ${ }^{3}$, NESSA E. O'CONNOR ${ }^{5}$, \\ EMMA SHEEHAN $^{2}$, RICHARD C. THOMPSON ${ }^{1} \&$ STEPHEN J. HAWKINS $^{6}$ \\ ${ }^{1}$ School of Geography, Earth and Environmental Science, Plymouth University, \\ Drake Circus, Plymouth PL4 8AA, United Kingdom \\ E-mail: Louise.firth@plymouth.ac.uk (corresponding author), \\ Antony.knights@plymouth.ac.uk, R.C.Thompson@plymouth.ac.uk \\ ${ }^{2}$ Marine Institute, Plymouth University, Drake Circus, Plymouth PL4 8AA, United Kingdom \\ E-mail: danielle.bridger@plymouth.ac.uk,emma.sheehan@plymouth.ac.uk \\ ${ }^{3}$ Institute of Biological, Environmental and Rural Sciences, \\ Aberystwyth University, Aberystwyth SY23 3DA, United Kingdom \\ E-mail: aje9@aber.ac.uk,pim2@aber.ac.uk \\ ${ }^{4}$ The Marine Biological Association of the United Kingdom, The Laboratory, \\ Citadel Hill, Plymouth PL1 2PB, United Kingdom \\ E-mail: nova@mba.ac.uk \\ ${ }^{5}$ School of Biological Sciences, Queen's University Belfast, Belfast, United Kingdom \\ E-mail: n.oconnor@qub.ac.uk \\ ${ }^{6}$ Ocean and Earth Science, National Oceanography Centre Southampton, Waterfront Campus, \\ University of Southampton, European Way, Southampton SOI4 3ZH, United Kingdom \\ E-mail: S.J.Hawkins@soton.ac.uk
}

The last few decades have seen rapid proliferation of hard artificial structures (e.g., energy infrastructure, aquaculture, coastal defences) in the marine environment: ocean sprawl. The replacement of natural, often sedimentary, substrata with hard substrata has altered the distribution of species, particularly non-indigenous species, and can facilitate the assisted migration of native species at risk from climate change. This has been likened to urbanization as a driver of global biotic homogenization in the marine environment - the process by which species invasions and extinctions increase the genetic, taxonomic, or functional similarity of communities at local, regional, and global scales. Ecological engineering research showed that small-scale engineering interventions can have a significant positive effect on the biodiversity of artificial structures, promoting more diverse and resilient communities on local scales. This knowledge can be applied to the design of multifunctional structures that provide a range of ecosystem services. In coastal regions, hybrid designs can work with nature to combine hard and soft approaches to coastal defence in a more environmentally sensitive manner. The challenge now is to manage ocean sprawl with the dual goal of supporting human populations and activities, simultaneously strengthening ecosystem resilience using an ecosystem-based approach. 


\section{Introduction: Context and background}

Human population growth is accelerating and is forecast to exceed 9.5 billion by 2050 (Bloom 2011, Gerland et al. 2014). Increasing demand for natural resources promotes further industrialization (Long et al. 2009) and leads to continued anthropogenic greenhouse gas emissions (Moss et al. 2010, van Vuuren \& Riahi 2011). Burgeoning human populations drive the exploitation of the ocean's energy and food resources through the construction of oil and gas platforms, marine renewable energy installations, and proliferation of aquaculture (Chapman \& Underwood 2011, Firth \& Hawkins 2011). Furthermore, increased use of transport hubs and global shipping is increasing the connectivity of coastal cities. The burning of fossil fuels continues to raise greenhouse gas levels, driving global climate change and sea-level rise, with the prospect of more extreme climatic events, including increased storm intensity and frequency (summarized in Intergovernmental Panel on Climate Change [IPCC] 2013, 2014).

Much of the recent human population growth is in vulnerable coastal regions (Small \& Nicholls 2003, Martínez et al. 2007), a trend predicted to continue. In conjunction with rising (Nicholls \& Cazenave 2010) and stormier (Bader et al. 2011) seas, our coastlines have become increasingly 'hardened' (Airoldi et al. 2005a, Moschella et al. 2005, Bulleri \& Chapman 2010, Chapman \& Underwood 2011, Firth et al. 2013a) with the proliferation of coastal defences. This is an adaptation option (sensu IPCC 2014) that has been adopted worldwide to protect the growing coastal population and its property, transport infrastructure, industry and commerce, as well as valuable amenity and recreational areas (for review, see chapters in Burcharth et al. 2007, Zanuttigh et al. 2014).

In this review, we discuss current evidence and thinking on biodiversity and ecosystem responses to global drivers of change, with a focus on recent rapid climate change and its interaction with regional and local impacts due to 'ocean sprawl'-the proliferation of artificial structures in the sea. We consider how efforts to combat climate change, such as mitigation via offshore renewables ('green' energies to reduce $\mathrm{CO}_{2}$ emissions), and adaptation via sea defences are leading to a proliferation of artificial structures, resulting in changes in the proportion of hard versus soft coastal habitats, the distribution of species, assemblage composition, and community structure. We also discuss the role of coastal development, including ports and other transport infrastructure as well as offshore structures (e.g., oil and gas platforms), in altering coastal and marine ecosystem structure and functioning. Finally, we undertake a critical review of the current 'state of the art' in the emerging field of 'green engineering', which combines environmentally conscious attitudes, values, and principles with science, technology, and engineering practice, all directed towards improving local and global environmental quality.

Our scope is the global coastline extending vertically to the uppermost extent of tidal influence, with particular emphasis on open coasts and offshore structures that have seen the most research. This is in contrast to the freshwater tidal reaches of estuaries, which have received little attention (but see Francis \& Hoggart 2008, 2009, Hoggart et al. 2012). Many of the case studies and examples are drawn from temperate systems in developed countries, reflecting the experience of the authors and the distribution of published research. Two themes permeate our review: firstly, how ecosystem services are at risk from modification of the coast by artificial structures; secondly, the interaction between the provision of new 'hard' substratum as a societal adaptation response, resulting in altered habitat connectivity and changes in the distribution of species and composition of assemblages. We conclude by identifying current knowledge gaps and future research needs.

\section{Burgeoning coastal human populations}

The diversity of coastal habitats includes rocky shores, sandy and muddy beaches, barriers, spits and sand dunes, estuaries and lagoons, deltas, wetlands, and coral reefs. These individually and 
collectively provide a disproportionately greater number of ecosystem services (see Millennium Ecosystem Assessment [MEA] 2005 for a discussion of provisioning, regulating, supporting, and cultural services) to human health and well-being per unit area than other systems (Costanza et al. 1997, Beaumont et al. 2007, Wyles et al. 2014). Globally, coastal systems are undergoing rapid environmental change, with developing countries particularly vulnerable (Figure 1; Crain et al. 2009, Cinner et al. 2012). The drivers of change are complex, but burgeoning human populations, coastal development, and climate change are ultimately responsible (Creel 2003). Consequently, coastal regions are home to some of the most threatened ecosystems in the world (Halpern et al. 2008, Waycott et al. 2009, Knights et al. 2015).

Nearly $40 \%$ of the global population lives within $100 \mathrm{~km}$ of the coast (Figure 1; Martínez et al. 2007), and population densities in these areas are generally high. In fact, 44 of the 71 cities (62\%) with over 5 million inhabitants are located on the coast; this is three times the global average (McGranahan et al. 2007, Seto et al. 2011, Smith 2011, IPCC 2013), and by 2030 it is estimated that $50 \%$ of the global population will live within $100 \mathrm{~km}$ of the coast (Small \& Nicholls 2003). Consequently, many of the world's coasts are becoming increasingly urbanized. Asia has shown the greatest intensification of population, property, and infrastructure at the coast (Jongman et al. 2012); 20 of the top $30(67 \%)$ most populated coastal cities are located in Asia, with Tokyo and Shanghai alone home to over 60 million people. Furthermore, 9 of 10 coastal cities with the highest proportional population change between 1990 and 2014 are in Asia with seven located in China (Figure 1; United Nations Environment Programme, Department of Economic and Social Affairs, Population Division [UNEP DESAP] 2014).

\section{Threats to coastal zones: coastal processes and coastal erosion}

\section{Sea-level rise and extreme climatic events}

Rates of sea-level rise have increased globally since records began (IPCC 2014) and are projected to continue to increase throughout the 2100s (Hinkel et al. 2014). Consequently, coastal habitats and their characteristic species (including those contributing to biogenic coastal defence) may experience 'coastal squeeze' wherein there is no opportunity for individuals to migrate inland or up-shore to escape rising sea levels (e.g., Doody 2004, Wolters et al. 2005, Jackson \& McIlvenny 2011).

In 2012, the IPCC released a special report on risk management and extreme climatic events; IPCC noted a marked increase in frequency and intensity of tropical cyclones in the North Atlantic since the 1970s (IPCC 2012), with coastal regions becoming prone to extreme flooding (Peduzzi et al. 2012). Recent history has been punctuated by such events, which have caused catastrophic human and economic losses in coastal areas (Brown et al. 2014). For example, the 2005 Atlantic hurricane season (the most active on record) included Hurricanes Katrina and Rita, which hit the Mississippi Delta, causing about 2000 deaths, about $\$ 91$ billion in damage, and $527 \mathrm{~km}^{2}$ of eroded wetlands along the coast of Louisiana (Beven et al. 2008, Howes et al. 2010).

More recently, in the winter of 2013-2014, Western Europe experienced an unprecedented prolonged sequence of stormy conditions (Huntingford et al. 2014, Matthews et al. 2014); the southwest and north-east of England and the western coast of Wales were particularly adversely affected. Collectively, the storms led to 17 deaths and clean-up costs of approximately $£ 1$ billion (Dodds 2014). The United Kingdom, however, was relatively well prepared. Following the 1953 storms and flooding in the North Sea when over 300 people died and 40,000 were left homeless, the UK government invested heavily in coastal defence infrastructure. The comparatively lower cost of human life and livelihood of 2013-2014 has been attributed to this improvement in coastal defence infrastructure (Sayers et al. 2015). 


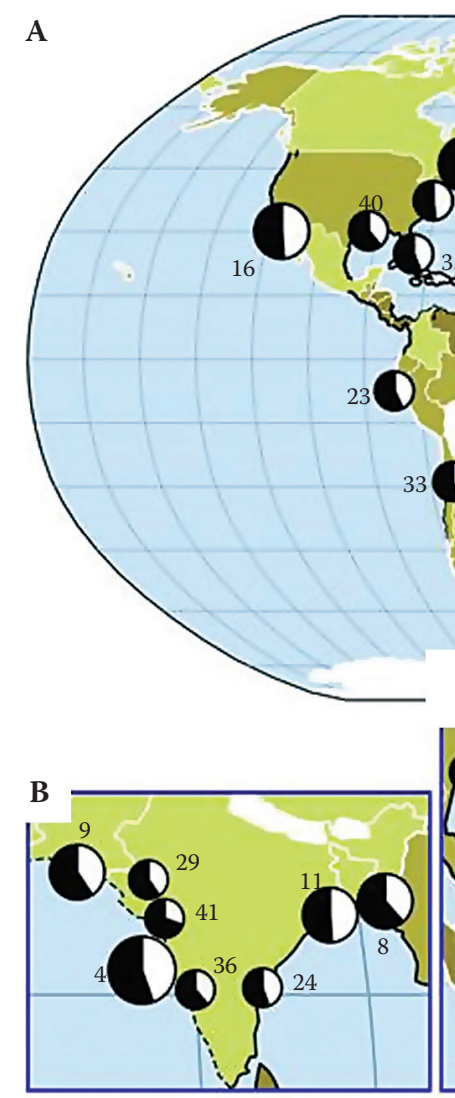

Coastal urban agglomerations Population size (2014)

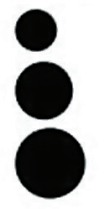
Large city ( $>5$ million people) Megacity (>10 million people) Megacity (>20 million people)

Population growth 1990-2030

D \% population growth 2015-2030 (projected)

$\%$ population growth 1990-2014
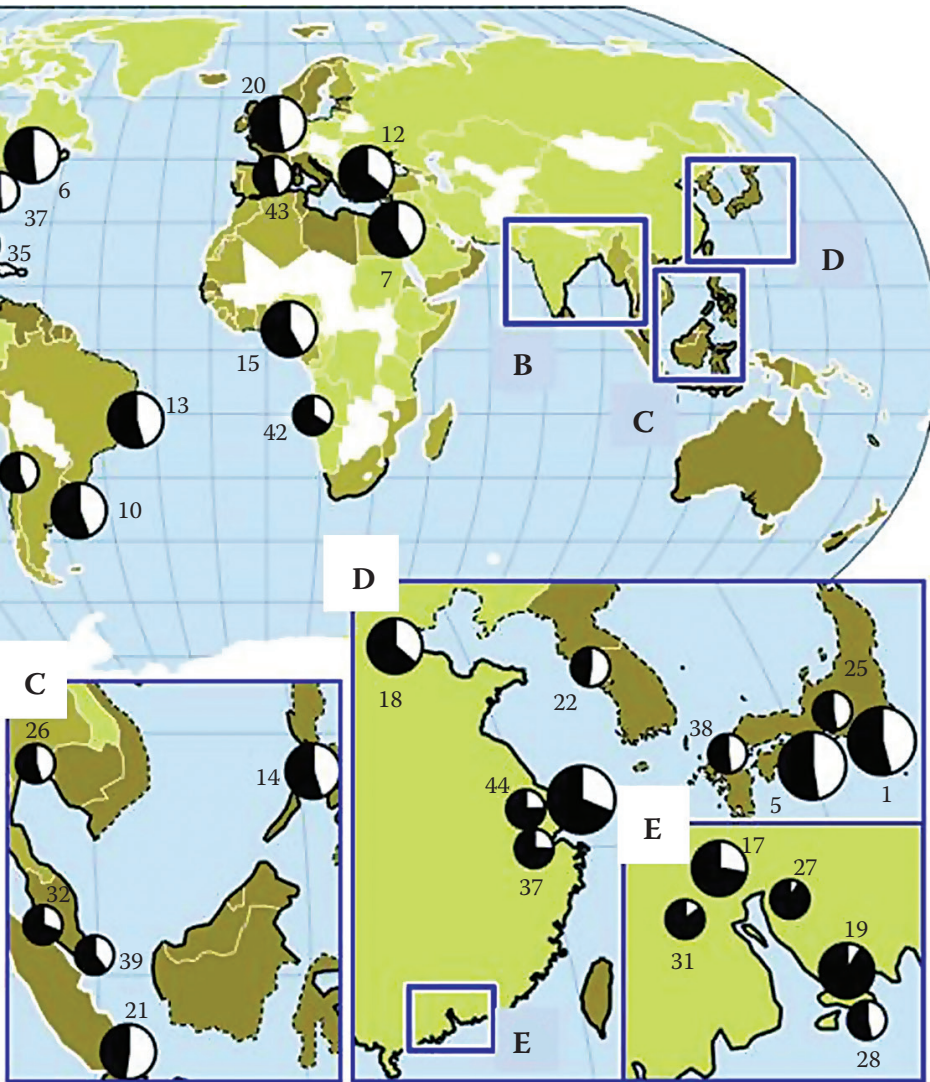

Coastal population

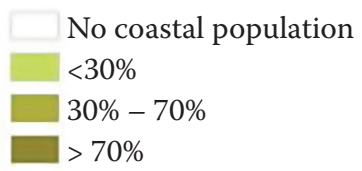

Coastline alteration

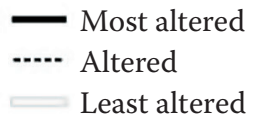

Figure 1 Large cities ( $>5$ million people) and megacities ( $>10$ million people), coastline alteration, and human populations living in coastal zones (within $100 \mathrm{~km}$ of coastline). (Coastline alteration redrawn from Rekacewicz, P. \& Ahlenius, H. 2006. Coastal population and altered land cover in coastal zones (100 km of coastline). http://www.grida.no/graphicslib/detail/coastal-population-and-altered-land-cover-in-coastal-zones100-km-of-coastline_7706, UNEP/GRID-Arendal. City population data from United Nations Environment Programme, Department of Economic and Social Affairs, Population Division [UNEP DESAP]. 2014. World Urbanisation Prospects: The 2014 Revision, Highlights (ST/ESA/SER.A/352). New York: United Nations, Department of Economic and Social Affairs, Population Division. Maps created by Shaun Lewin, Plymouth University.) 

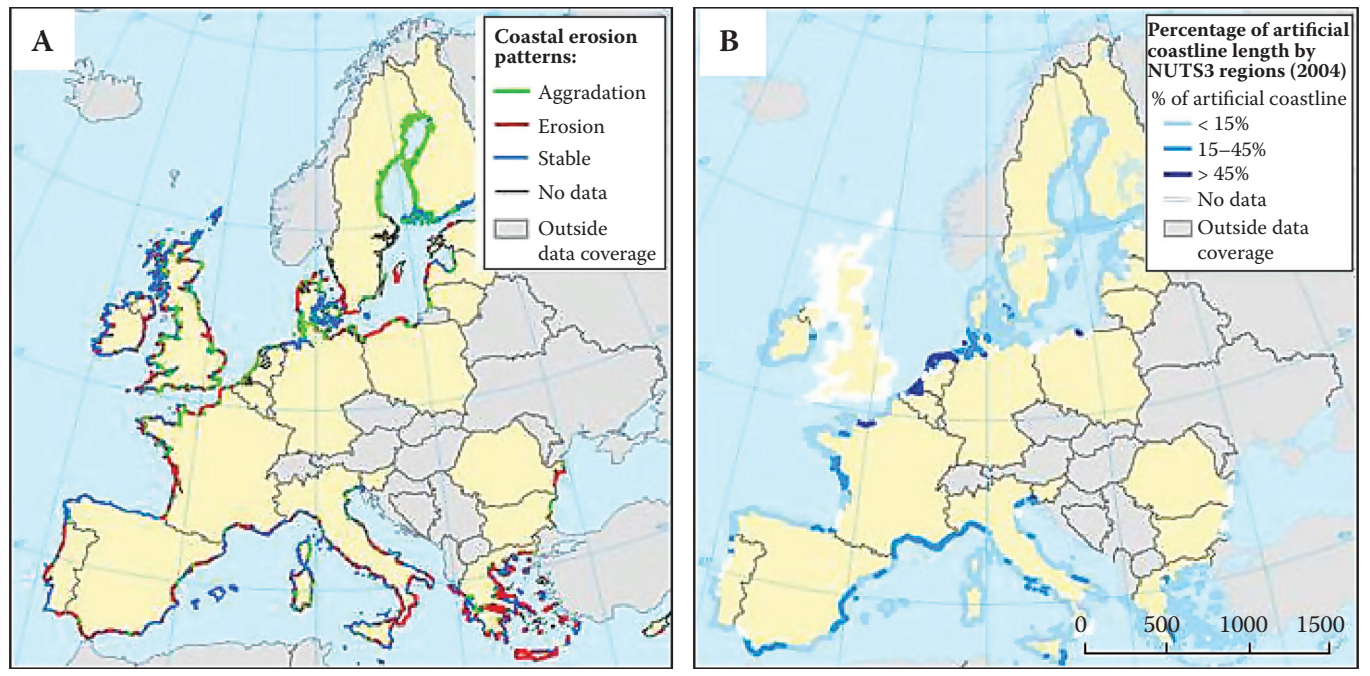

Figure 2 (A) The distribution of accreting, eroding, and stable coastlines of Europe (data from Eurosion. 2004. Living with coastal erosion in Europe: sediment and space for susceptibility. Part IV_A guide to coastal management practices in Europe: lessons learnt. http://www.eurosion.org/reports-online/part4.pdf, accessed 11 May 2015). (B) The percentage of artificial coastline. (Maps courtesy of the European Environment Agency [EEA], http://www.eea.europa.eu/legal/copyright.)

\section{Coastal erosion}

The combination of climate change, sea-level rise, and increasing storm frequency will lead to more severe coastal erosion and flooding over the next few decades (Hulme et al. 2002, Thompson et al. 2002, Hirabayashi et al. 2013, IPCC 2014). To assess the threat, two comprehensive assessments have been undertaken in Europe (Eurosion 2004) and the United States (National Oceanic and Atmospheric Administration [NOAA] 2012) to evaluate the state of the coasts and risk of erosion. Based on data collected from 22 coastal countries, Eurosion (2004) concluded that $15 \%$ of the coastline of Europe was actively eroding (Figure 2A) and that 6.4\% was artificially stabilized (Figure 2B). Given recent investment, the latter figure is likely to be much higher now. More recently, the NOAA State of the Coast project (NOAA 2012) collected data from 28 coastal states and found that $36 \%$ of the coastline of the United States was highly vulnerable to erosion, and that $9 \%$ was protected using hard armouring and an estimated 350,000 structures located within $150 \mathrm{~m}$ of the shoreline.

In the United Kingdom, the south-eastern coast of England is characterized by soft sedimentary geology that is vulnerable to erosion. The village of Happisburgh, Norfolk, is often used as a case study to illustrate the dramatic impacts of coastal erosion on coastal communities. Although now a coastal village, Happisburgh was once some distance from the sea. Historic records indicate that over $250 \mathrm{~m}$ of land were lost between 1600 and 1850, prompting the use of coastal defences (groynes) to protect the shoreline. Removal of the groynes in 1991 led to the erosion of about $36,000 \mathrm{t}$ of sediment, a landward retreat of about $100 \mathrm{~m}$, and the creation of an obvious embayment (Figure 3; Poulton et al. 2006, Brown et al. 2014).

\section{Coastal habitats: natural coastal defence}

Coastal habitats are an important interface between the land and the sea. All coastal habitats are ultimately geological in origin (geogenic) but can be reshaped by biological processes (biogenic). Biogenic habitats can be defined as vegetated (e.g., kelp forests, seagrass beds, mangroves, and salt marshes) or 

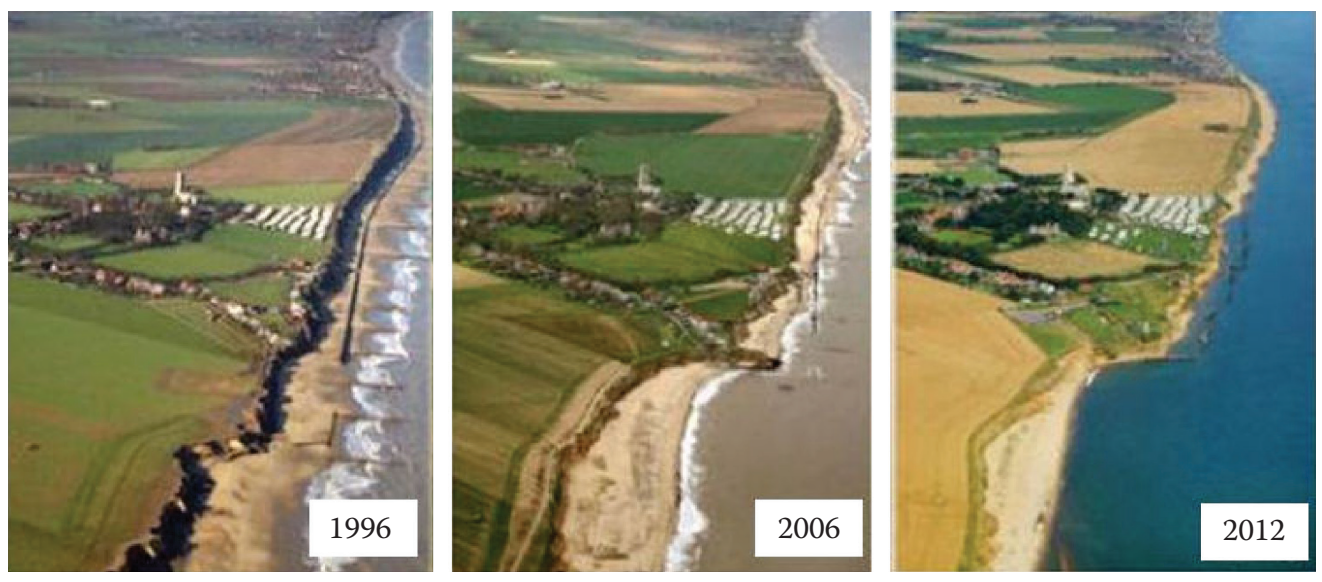

Figure 3 The eroding coastline at Happisburgh, Norfolk, United Kingdom. The removal of the groynes in 1991 led to severe coastal erosion and a landward retreat of about $100 \mathrm{~m}$. (Photos copyright Mike Page.)

as 'biogenic reefs' - habitats formed by animals such as corals, bivalves (e.g., oysters and mussels), and annelids (e.g., honeycomb worms). Geogenic and biogenic habitats provide a key ecosystem service to coastal communities of protection against wave damage and erosion caused by storms (Badola \& Hussain 2005, Koch et al. 2009, Barbier et al. 2011); hurricanes/typhoons (Day et al. 2007, Costanza et al. 2008); and tsunamis (Dahdouh-Guebas et al. 2005, Alongi 2008, Marois \& Mitsch 2015).

\section{Geogenic habitats}

Rocky coasts form about $80 \%$ of the world's coastline (Emery \& Kuhn 1982). By their very nature, rocky coastlines offer significant coastal protection, forming a physical barrier between the land and the sea. Coastlines characterized by softer lithology are more susceptible to both physical (Naylor et al. 2010, Brooks \& Spencer 2012) and biological erosion (see Naylor et al. 2012, Coombes 2014 for reviews), making them more susceptible to flooding and damage to infrastructure and assets. Soft chalk and calcareous coastlines are particularly vulnerable to erosion by bivalves (e.g., piddocks; Pinn et al. 2005a, 2008), which can be a threat to artificial limestone breakwaters (e.g., Lithophaga lithophaga, Devescovi \& Iveša 2008).

Sandy habitats (sand bars, beaches, and dunes) have been shown to play an important role in the prevention of coastal erosion (Doody 2012, Hanley et al. 2014). These geogenic habitats are more dynamic than rocky coasts and have an important coastal protection function in many parts of the world (e.g., the North Sea coasts of Germany, Netherlands, and Belgium, see Hanson et al. 2002, Stive et al. 2013, van der Meulen et al. 2014; south-eastern Australia, see Short \& Hesp 1982; the western United States, see Wiedemann \& Pickart 1996). Their function as a coastal defence 'structure' is greatly enhanced by the associated vegetation (e.g., Feagin et al. 2005), such as seagrass at the seaward boundary and salt marsh and mangroves at the land-sea interface. Vegetation is not always advantageous. For example, since the introduction of the European marram grass Ammophila arenaria to the western coast of North America in 1868 to stabilize dunes in the San Francisco area, it has since spread along the entire western coast of North America, displacing native plant species and altering sediment dynamics (Wiedemann \& Pickart 1996).

\section{Biogenic habitats}

Biogenic habitats are ubiquitous in coastal marine and estuarine systems worldwide but vary in extent and species composition across biogeographic regions (Figure 4). For example, at lower 


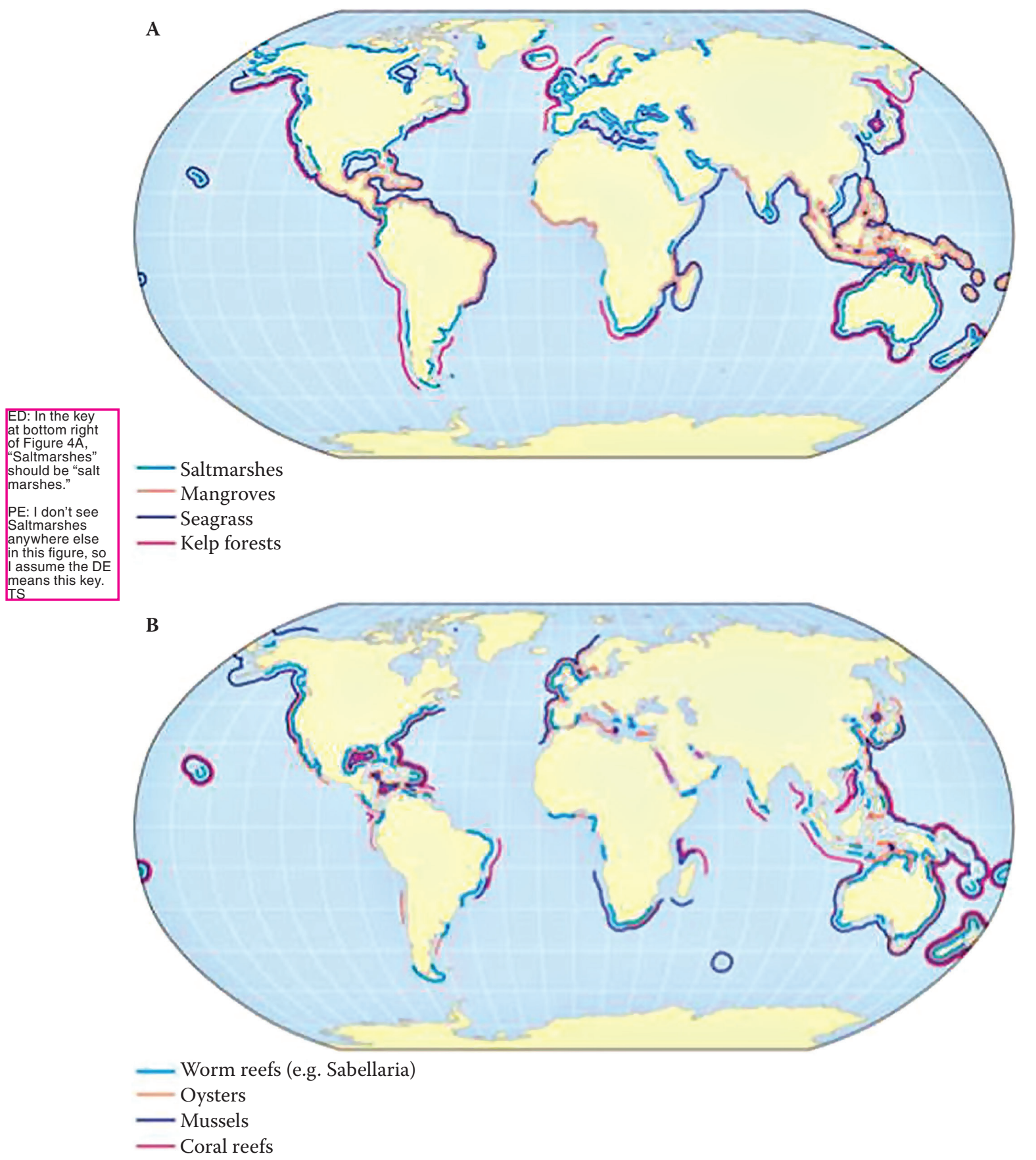

Figure 4 Global distribution of (A) vegetated coastal habitats (kelp, seagrass, mangroves) and (B) coastal biogenic reefs (coral, mussels, oysters, worms). (Data extracted from the Global Biodiversity Information Facility, http://www.gbif.org/, and United Nations Environment Programme Ocean Viewer, http://data.unepwcmc.org/datasets/6. Maps created by Shaun Lewin, Plymouth University.) 
latitudes mangroves occupy the niche exploited by salt marshes at higher latitudes; warm-water coral reefs only occur in the shallow tropics and subtropics, whereas kelp forests and large fucoid beds are only present in shallow waters at higher latitudes or in upwelling regions (e.g., in Oman, Sheppard \& Salm 1988). Biogenic habitats have the potential to provide the 'front line' of natural coastal protection and have been referred to as "biogenic coastal defences" (Mork 1996, Koch et al. 2009, Arkema et al. 2013, Bouma et al. 2014). Here, we focus on their roles in wave attenuation and coastal protection.

The value of biogenic coastal defences is dependent on the timing of natural processes such as storms, hurricanes and typhoons, and tsunamis (Koch et al. 2009). Protection will be diminished if storms occur when biomass or density of the biogenic structure is low. This may be of particular importance in temperate regions, where seasonal patterns of peak biomass (usually late summer) may be mismatched with the seasonal occurrence of storms in autumn and winter (Koch et al. 2009). In contrast, the biomass of biotic structures in tropical areas tends to be less variable over time (Tam et al. 1995), and the coastal protection service they provide may be more predictable throughout the year.

\section{Kelp forests and large fucoid beds}

Kelps (e.g., Macrocystis, Nereocystis, Laminaria spp.) and fucoids (e.g., Fucus, Durvillea, Ascophyllum spp.) are large, brown seaweeds that typically grow on subtidal and intertidal rocky reefs in temperate and polar waters (Figure 4A; Steneck et al. 2002). In comparison to other biogenic coastal defences, little is known about the role of kelps in coastal protection (Smale et al. 2013). They protect rocky coastlines and adjacent sedimentary habitats by attenuating wave energy, buffering against storm surges, and preventing the movement of sediments from adjacent beaches (Mork 1996, Rosman et al. 2007). The degree of wave attenuation is strongly influenced by the architecture of the dominant kelp species (i.e., prostate, stipitate, canopy) and the community structure of the understorey canopy (Eckman et al. 1989, Türker et al. 2006, Gaylord et al. 2007) and, as such, will vary between biogeographic regions (Smale et al. 2013). Far less attention has been given to the role of fucoids in coastal protection on rocky reefs, although Tyrrell et al. (2015) described how fucoid algae in salt marshes can attenuate wave energy and play a significant role in sediment deposition and accretion.

\section{Seagrass beds}

Seagrasses occur in shallow sedimentary habitats and have a wide geographic distribution (Figure 4A; Short et al. 2007). They are often found adjacent to salt marshes in temperate regions (e.g., Irlandi \& Crawford 1997). Seagrasses can alter the environment by stabilizing sediments, reducing current velocity, and dissipating wave energy (Koch 2001, Christianen et al. 2013, Maza et al. 2013). Ondiviela et al. (2014) reviewed the role of seagrasses as coastal protection and concluded that the larger, longer-living, and slower-growing species (e.g., Thalassia testudinum, Posidonia oceanica, Zostera marina) provided the most effective protection, although short-leaved, low-biomass, and heavily grazed seagrasses can also significantly reduce coastal erosion (Christianen et al. 2013). The relative importance of seagrasses for wave attenuation is strongly related to both physical setting (bathymetry, hydrodynamics, sediment regime) and biological factors such as standing biomass, shoot density, and leaf length (Fonseca \& Cahalan 1992, Bouma et al. 2010, Stratigaki et al. 2011, Paul et al. 2012). Despite seagrasses clearly providing some coastal protection, this service is perhaps limited compared to salt marshes (Bouma et al., 2005), on one hand due to their natural fragility and flexibility (La Nafie et al. 2012, Paul et al. 2012) and on the other due to their placement, which tends to be in the shallow subtidal zone with therefore less potential to attenuate wave energy (Paul et al. 2012). 


\section{Mangroves}

Mangroves typically occur in tropical regions, but they also occur on the temperate northern coast of New Zealand and southern coast of Australia (Figure 4A), where they occupy sedimentary estuarine and low-energy marine environments (Spalding 2010). It has long been known that the complex architecture provided by mangroves is important for buffering wave energy (Othman 1994, Mazda et al. 2006, Aziz et al. 2013). The importance of mangroves as coastal protection received much attention following the Asian tsunami in 2004 (Dahdouh-Guebas et al. 2005, Danielsen et al. 2005), but subsequent studies have argued that their protection against extreme events such as tsunamis may in fact be limited (Alongi 2008, Cochard et al. 2008). More research is required on the role of mangroves in protection from tsunamis, cyclones, and hurricanes.

\section{Salt marshes}

Salt marshes occupy the coastal fringes in temperate regions (Figure 4A; Deegan et al. 2012), where they form a natural physical barrier to tidal and storm activity (Koch et al. 2009, Gedan et al. 2011, Temmerman et al. 2013). Bouma et al. (2014) discussed how the degree of wave attenuation varies in relation to a combination of physical (e.g., hydrodynamics and sediment dynamics; Möller et al. 2011, Shepard et al. 2011, Ysebaert et al. 2011, Yang et al. 2012) and biological (e.g., vegetation biomass and stiffness; Bouma et al. 2005, 2010) factors. Less is known about the role of salt marshes in response to extreme weather events and rising sea levels. Recent studies of storm surges found that the presence of saltmarsh vegetation was linked to considerably enhanced wave attenuation even when water level and wave height were greatest (Möller et al. 2014). Thus, salt marshes are a valuable component for sediment stabilization and coastal protection under predicted global change scenarios.

The erosion of salt marsh and 'coastal squeeze' are common in estuarine regions such as the south-eastern coast of England (Cooper et al. 2001, Foster et al. 2013). Here, management practices include managed coastal retreat and realignment, by which traditional hard coastal defences are moved inland to restore intertidal wetlands and create natural defences in the form of mudflatsaltmarsh systems. Restoring salt marshes through coastal realignment (Mossman et al. 2012) in Essex, England, not only provided enhanced tidal defences but also protected biodiversity and its associated ecosystem services.

Saltmarsh pioneers in the genus Spartina were extensively transplanted in the nineteenth and early twentieth century to stabilize coastlines worldwide (Strong \& Ayres 2009, Pratolongo 2013). This had many unintended consequences, including hybridization with local species to produce Spartina anglica (Ainouche et al. 2004, Salmon et al. 2005) that outcompeted native species (Callaway and Josselyn 1992, Gedan et al. 2009, Silliman et al. 2009). In many places there are now major attempts to control proliferation of Spartina due to the loss of mudflats and valuable birdfeeding grounds (Wang et al. 2006, An et al. 2007, Patten \& O'Casey 2007). Thus care is needed in assessing potential trade-offs between ecosystem services and desired end points if salt marshes are being deliberately enhanced for coastal defence.

\section{Linkages between habitats and systems}

There is increasing recognition of the importance of facilitative interactions and the role of organismal ecosystem engineering in establishing the structure of communities (e.g., Altieri et al. 2010, Passarelli et al. 2014). By combining field measurements of wave attenuation in salt marshes, oyster reefs, and mussel beds with modelled data from seagrasses, van Belzen et al. (unpublished) investigated the up-shore facilitation between different coastal habitats under different tidal regimes and landscapes. They found that in small tidal ranges, habitats reside within each other's wake zone, creating an up-shore facilitative cascade across the tidal gradient and maximal wave dissipation 
in the most 'connected' systems. However, continuity among habitats can diminish at greater tidal ranges, jeopardizing ecosystem stability with potential consequences for coastal safety.

Dislodged macroalgae and other plants that have been exported from rocky shores and seagrass beds following disturbance are a distinctive feature of many depositing shores, and this export has been shown to indirectly contribute to coastal stabilization by providing nutrients to the flora of beach and dune systems (Colombini et al. 2003, Orr et al. 2005, Williams \& Feagin 2010, Doody 2013). Similarly, human-mediated removal of macroalgal debris and its use as fertilizer has led to soil formation and stabilization of dune systems, creating the characteristic 'machair' systems of the western coast of Ireland and the Scottish Outer Hebrides (Owen et al. 2001, Kent et al. 2003, Doody 2013). Conversely, there is also some evidence that deposited seaweed can have an impact on salt marshes, leading to mortality of some species (Davies et al. 2011, 2012), perhaps compromising their role in attenuation of waves and stabilization of sediments.

\section{Biogenic reefs}

In comparison to vegetated habitats, far less is known about the role of biogenic reefs in coastal protection (Bouma et al. 2014). Biogenic reefs in tropical regions are typically formed by the calcium carbonate secreted by reef-building corals and algae and are found in shallow-water settings (Figure 4B; Huang \& Roy 2015). Wave attenuation by coral reefs is a function of the water depth above the reef, but these relationships are non-linear (Kench \& Brander 2006, Barbier et al. 2008). In a global meta-analysis, Ferrario et al. (2014) found that coral reefs provide substantial protection against natural hazards by reducing wave energy by an average of $97 \%$, and that reef crests alone dissipate $86 \%$ of this energy.

Biogenic reefs in temperate regions are created by organisms such as oysters, mussels, or honeycomb worms (e.g., Gunnarea spp., Phragmatopoma spp., Sabellaria spp.) (Figure 4B; Barbier et al. 2008, Dubois et al. 2009). While it is widely accepted that coral and oyster reefs provide an important coastal protection service (Piazza et al. 2005, Beck et al. 2009, Scyphers et al. 2011), far less is known about the role of mussel reefs (but see Borsje et al. 2011, Donker et al. 2013). In a study comparing the relative importance of the two habitats in the Netherlands, Borsje et al. (2011) concluded that oyster beds were more effective in wave attenuation compared to mussel beds. Interestingly, the oyster investigated was Crassostrea gigas - a species not native to the region. This is an intriguing example of an ecosystem service delivered by a non-indigenous species. Honeycomb worms can form sizable structures and cover large areas in some parts of their range (e.g., Sabellaria alveolata in north-western Europe; Dubois et al. 2002, 2006, Desroy et al. 2011, Firth et al. 2015a) and may play a significant role in wave attenuation and coastal protection. However, no data currently exist on this potentially important ecosystem service (Bouma et al. 2014).

\section{Global loss of natural coastal defences}

Degradation and loss has been observed for all habitats with the potential to act as biogenic coastal defences. For example, $85 \%$ of oyster reefs (Beck et al. 2011), 65\% of seagrasses (Lotze et al. 2006), $50 \%$ of salt marshes (Gedan et al. 2009), 35\% of mangroves (Valiela et al. 2001), and 30\% of coral reefs (Valiela et al. 2001) have been lost or are in a degraded state, and the rate of loss is expected to increase in the future (Lotze et al. 2006, Waycott et al. 2009, Barbier et al. 2011). There are currently no reports in the literature of global loss or decline for kelp forests, other macroalgal beds, mussel beds, or worm reefs, but there is considerable evidence for regional losses. Examples include kelp forests in the United States (Byrnes et al. 2011), canopy algae in Australia (Connell \& Irving 2008, Wernberg et al. 2011) and the Mediterranean (Bulleri et al. 2010, Perkol-Finkel \& Airoldi 2010), and mussel reefs in Northern Ireland (Strain et al. 2012, Cook et al. 2013). The drivers of this change are complex, but burgeoning human populations, coastal development, and climate change play a significant role (Creel 2003). 


\section{'Ocean sprawl': the proliferation of artificial structures in offshore and coastal waters}

Ocean sprawl implies the proliferation of coastal and offshore artificial structures (Thompson et al. 2002, Airoldi et al. 2005a, Villareal et al. 2007, Inger et al. 2009, Firth \& Hawkins 2011). These structures are built for a variety of functions, including coastal defence, oil and gas extraction, aquaculture, and more recently, marine renewable energy (Figure 5; Bacchiocchi \& Airoldi 2003, Witt
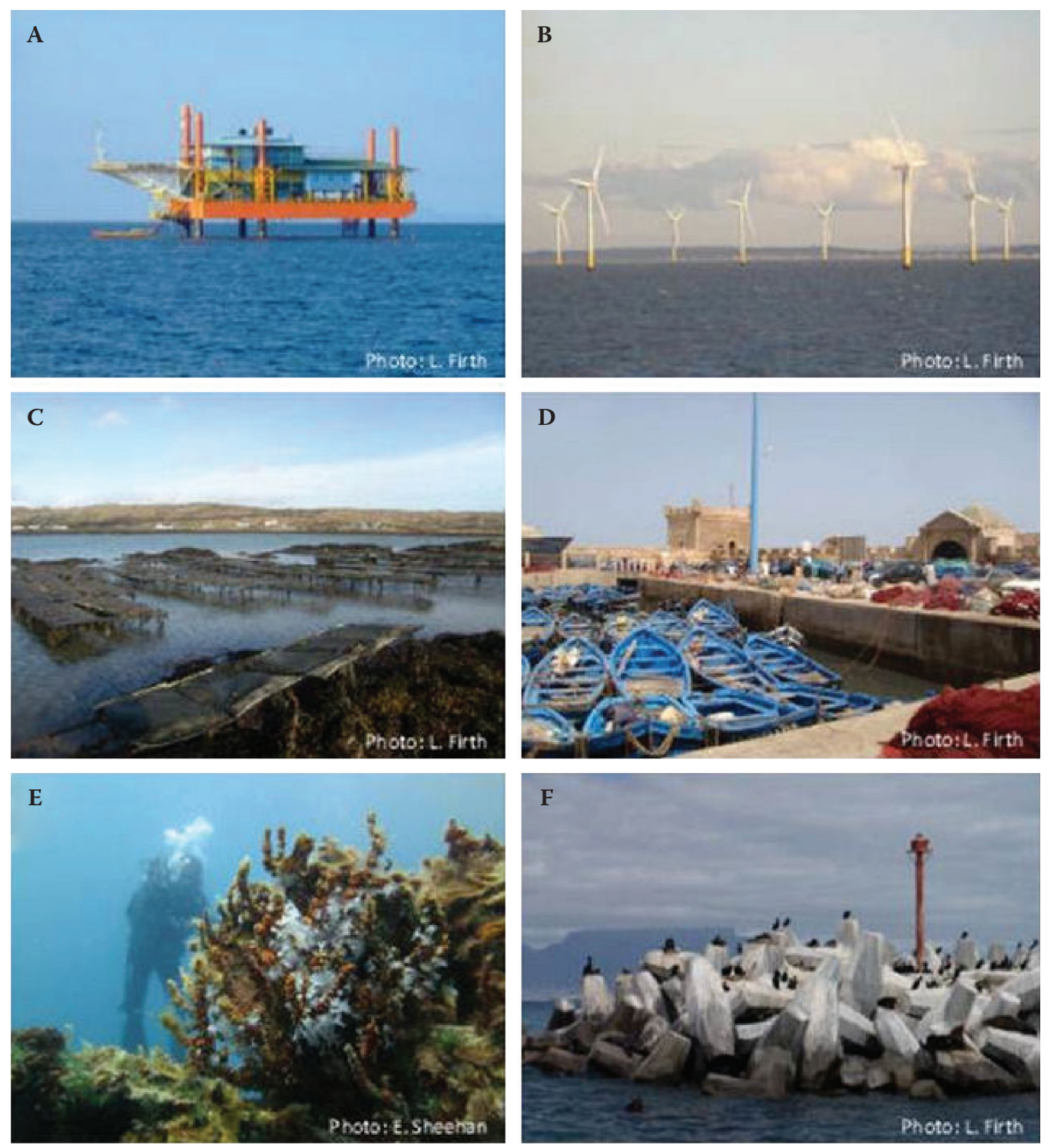

Figure 5 Examples of ocean sprawl-the proliferation of artificial structures in the sea. (A) Oil and gas platforms: Seaventure, Borneo, Malaysia. (B) Offshore renewable energy installations: Liverpool Bay, United Kingdom. (C) Shellfish aquaculture: oyster trestles, Galway Bay, Ireland. (D) Ports, harbours, and marinas: Essaouira, Morocco. (E) Artificial reefs: HMAS Swan, Dunsborough, Australia. (F) Coastal defence structures: Robben Island, South Africa. 


\section{LOUISE B. FIRTH ET AL.}

et al. 2012). The impacts of these structures on the environment have been the subject of several reviews (Airoldi \& Beck 2007, Govaerts \& Lauwaert 2009, Bulleri \& Chapman 2010, Dugan et al. 2011), and we do not discuss these impacts here. Instead we review the variety and scope of these structures to provide habitat for benthic organisms.

\section{Artificial structures associated with energy production}

The generation of energy from renewable resources continues to move up the political agenda for many countries due to the link between non-renewable fossil fuels and global climate change (Dincer 1999, Chow et al. 2003). Countries with coastlines have plentiful and predictable renewable energy resources in the form of offshore wind, tides, waves, and currents. Considerable attention is therefore being directed towards coastal waters as a source of offshore renewable energy (Figure 6; Pelc \& Fujita 2002, Gill 2005).

\section{Marine renewable energy installations}

The location of wind turbines offshore on pylons was first suggested in the 1930s, but it was not until 1991 that the first offshore turbines ('World Wind') were installed $250 \mathrm{~m}$ off the coast of Sweden (Nikolaos 2004, Bilgili et al. 2011). After more than 30 years of development, Europe has become the front runner in the commercialization and utilization of offshore wind power technology (Figures 5B, 6B), with 74 installations (2488 turbines) spanning 11 countries and comprising more than 91\% of all global offshore wind (Global Wind Energy Council [GWEC] 2014). Until recently, this was the only region in the world with operational capacity. While governments outside Europe have been slower to use this technology, many countries, including China, Japan, India, South Korea, Taiwan, and the United States, have begun to set ambitious targets (Figures 6C, 6D; Lewis 2011, GWEC 2014, Yang et al. 2015).

Large amounts of energy can also be harnessed in coastal areas using tide or wave action. Traditionally, tidal projects have involved extensive barrage systems, which are used to block estuaries. Their energy-harnessing turbines are driven by tidal flow and are particularly effective in areas of large tidal range (e.g., Brittany, France, and the Bay of Fundy, Canada) (Pelc \& Fujita 2002). In the United Kingdom, the large-scale Tidal Lagoon Swansea Bay represents a large-scale project that, once built, will combine energy generation technology and green engineering with recreation and amenity facilities. Wave energy is considered to be one of the most promising renewable technologies (Pelc \& Fujita 2002), with pilot projects including Limpet 500 off Islay, Scotland (Westwood 2004), and Wave Hub, Cornwall, England (Witt et al. 2012).

\section{Oil and gas platforms}

Despite the shift towards offshore renewable energy solutions, there are still thousands of offshore oil and gas platforms operating worldwide (Figure 5A). These are among the largest artificial structures in the marine environment (Patin 1999, Hamzah 2003). Globally, there are more than 7500 offshore platforms (Parente et al. 2006) located on the continental shelves of 53 countries, predominantly in the Gulf of Mexico (4500 current installations), with 950 in East Asia, 550 in West Africa, and 490 in the North Atlantic and North Sea (reviewed in Doyle \& Havlick 2009). A 40- to 60-m platform has approximately $8-12 \mathrm{~km}^{2}$ of surface area that can be colonized by fouling communities (Bull 1989) and can serve as habitat for 10,000-20,000 fish (Stanley \& Wilson 1997). Offshore platforms have a production lifespan of about 17.5 years (Pulsipher et al. 2001) before they are decommissioned and removed or converted to artificial reefs, for example, through the Rigs-toReefs (RTR) programme (Kaiser \& Pulsipher 2005). 


\section{OCEAN SPRAWL}
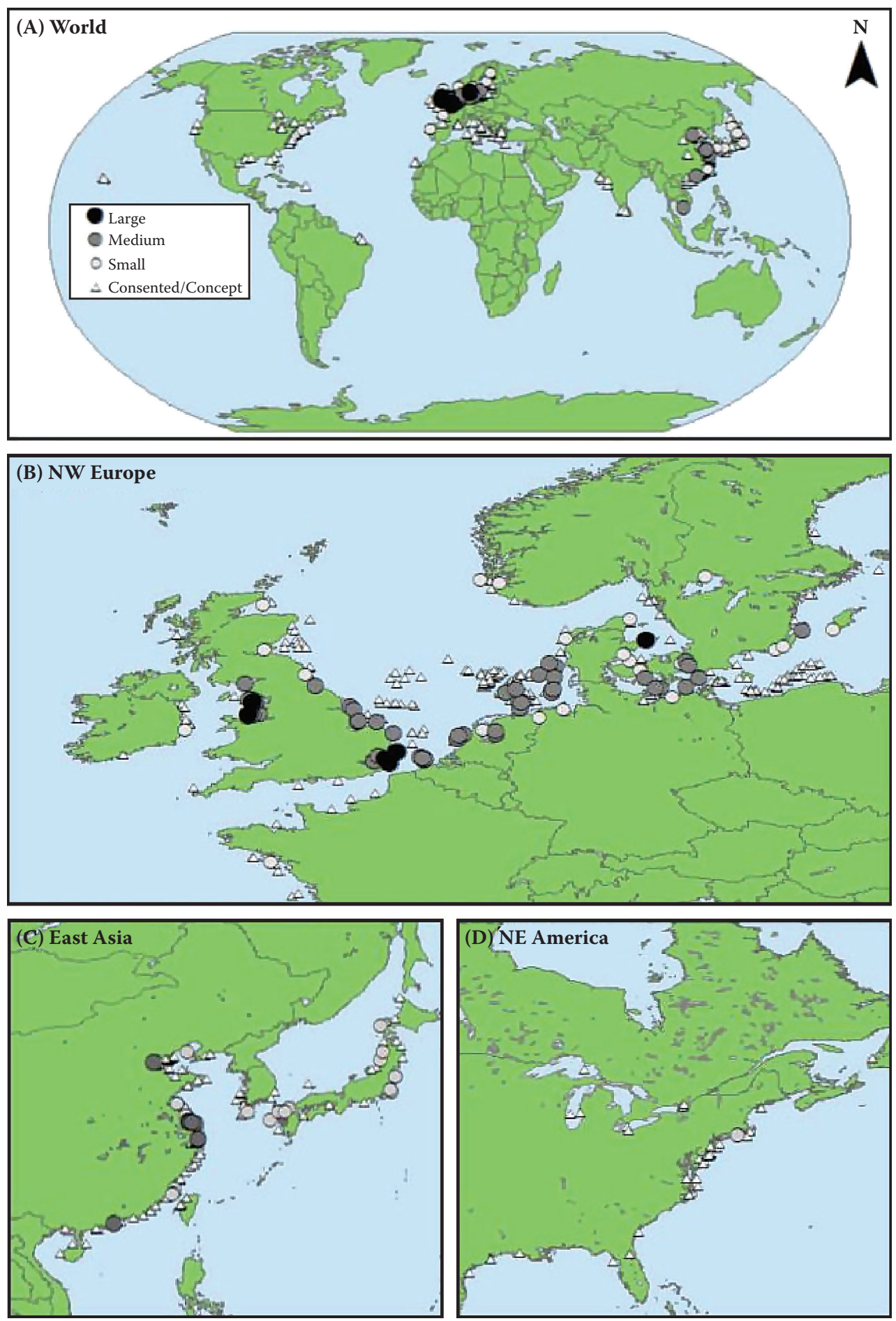

Figure 6 (A) Global distribution of operational and planned offshore wind farms. Note that the major hubs are located in (B) north-western Europe (2480 existing and 812 planned turbines), (C) East Asia (27 existing and 295 planned turbines), and (D) the north-eastern United States (5 turbines under construction, no data on numbers planned). (Data obtained from 4C Offshore; maps created by Danielle Bridger, Plymouth University.) 


\section{LOUISE B. FIRTH ET AL.}

\section{Artificial structures associated with food production}

\section{Artificial reefs}

An artificial reef is a submerged structure intentionally placed on the seabed that mimics characteristics of natural reefs (Carr \& Hixon 1997, Jensen 1998). Uses of artificial reefs include habitat rehabilitation (Baine 2001) and fisheries enhancement (Collins et al. 1994, Pickering \& Whitmarsh 1997, Jensen et al. 2000), but they can also be used to enhance recreation and tourism, for example, angling, surfing, and recreational diving (Figure 5D; Stolk et al. 2007). Increasingly, artificial reefs are being constructed with a primary function of wave energy dissipation and a secondary function of habitat rehabilitation (Hirose et al. 2002, Scyphers et al. 2015).

\section{Structures associated with finfish and shellfish aquaculture}

There is increasing concern about the impacts of the placement of semi-permanent fishing equipment (Nugues et al. 1996). One example of this is crab-tiling: Bait collectors lay hard structures (e.g., car tyres and roof tiles) on estuarine mudflats and sand flats to provide shelter for crabs (Sheehan et al. 2010a). While the structures may have a positive effect on crabs on a small spatial scale (Sheehan et al. 2008), the practice has wider negative impacts on infaunal and bird communities (Johnson et al. 2007, Sheehan et al. 2010b, 2012).

At intermediate spatial scales, lobster shelters ('casitas'; Gutzler et al. 2015), oyster trestles (Figure 5C), and crab and lobster pots are contributing to the proliferation of hard structures in the sea and can attract considerable coverage of ephemeral fouling organisms such as barnacles and tube-forming polychaetes (Southward 1995). On a larger scale, the structures associated with finfish aquaculture can add a substantial amount of artificial material and, given the location of this industry, can lead to hardening in both nearshore and offshore waters. While the impacts of these structures on the receiving environment has received much attention (e.g., Ruiz et al. 2001, Callier et al. 2013), relatively little is known about the epibenthic communities that foul these structures or their role in facilitating the spread of both native and non-indigenous species (but see Naylor et al. 2001).

\section{Artificial structures associated with urbanization and climate change}

\section{Ports, harbours, and marinas}

Ports and harbours (hereafter ports) are required for the transport of people and cargo between countries. World Port Source (http://www.worldportsource.com) lists over 4700 ports within 295 countries globally. The five countries with the highest number of ports are the United States (532), United Kingdom (389), Italy (311), Japan (292), and Canada (239). A further six countries have over 100 ports: China, Denmark, France, Indonesia, Australia, and Greece. The construction of ports generally leads to land reclamation and the linearization of the coastline due to the construction of straight-sided docks, piers, and mooring seawalls (Figure 7). In addition to the creation of thousands of kilometres of artificial habitat, marine shipping activities connecting these ports on local, regional, and global scales are responsible for the spread of a wide range of invasive species (Floerl \& Inglis 2005, Floerl et al. 2009), a process recognized as a key anthropogenic driver of global biotic homogenization.

As the size of vessels has increased, there has been a switch from traditional hold storage of cargo to containers, leading to many traditional port installations becoming redundant (Russell et al. 1983, Allen et al. 1992, 1995, Conlan et al. 1992, Hawkins et al. 1992a,b). As ports became increasingly obsolete from the 1970s onward, many were modified for alternative uses, including fish farms, housing, and tourist attractions (Russell et al. 1983, Hawkins et al. 1992a). 


\section{OCEAN SPRAWL}

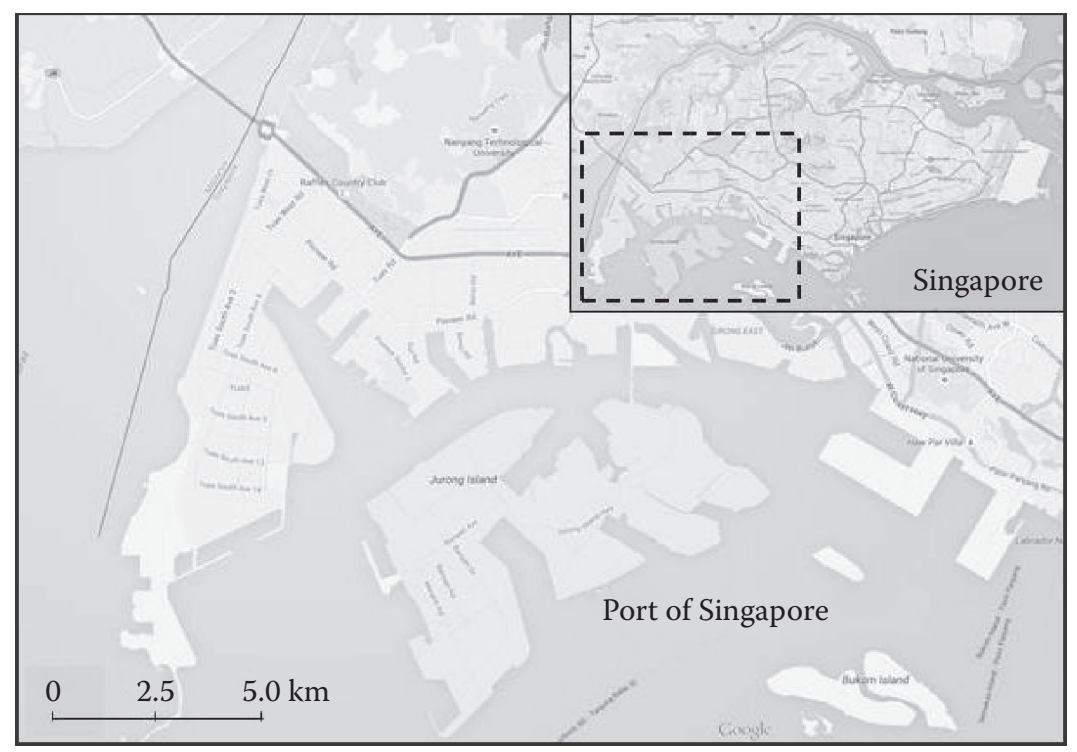

Figure 7 The Port of Singapore (inset), the second-largest port in the world (Esri 2013), which handled 32.2 million TEU (20-foot equivalent units) in 2013 (http://www.worldshipping.org). Note the linearization of the coastline. (Images from Google Earth.)

\section{Artificial coastal defence structures}

Coastlines are increasingly defended by engineered 'armouring' structures (Airoldi et al. 2005a, Charlier et al. 2005, Moschella et al. 2005, Chapman \& Underwood 2011), including shore-parallel (e.g., seawalls, bulkheads, revetments) and shore-perpendicular structures (e.g., groynes, jetties, and breakwaters; Figure 5F) (Chapman \& Bulleri 2003, Dugan et al. 2011). The primary goal of hardarmoured coastal defences is to protect property, infrastructure, and other landward assets from flooding and erosion (Salman et al. 2004, Charlier et al. 2005). These structures can be very large (e.g., La Spezia Breakwater, Italy, and Plymouth Breakwater, England) or can be placed in close proximity to one another, thus creating a network of artificial structures that can span extensive stretches of coastline (e.g., Cesenatico, Italy; Airoldi et al. 2005a, Dafforn et al. 2015a).

In some regions coastlines have become extensively artificial (Stancheva et al. 2011). For example, coastal armouring is reported to cover more than $89 \%$ of the natural shoreline in Monaco (http://www.medam.org); 85\% of Belgium (Gregory 2010); 63\% of Singapore (Lai et al. 2015); and $60 \%$ of the Netherlands and China (Eurosion 2004, Guan 2013). There is increasing concern that artificial structures are acting as 'stepping stones' between regions that facilitate the spread of invasive species (e.g., Airoldi et al. 2015), although the extent to which they are acting in this manner remains poorly understood and an important knowledge gap within the field of coastal ecology.

\section{Artificial islands}

In some places, the construction of artificial islands and associated coastal armouring has dramatically increased the linear extent of shoreline. An extreme example of this can be seen in Dubai (Figure 8A), where initially there were plans to increase the $45-\mathrm{km}$ coastline to more than $1500 \mathrm{~km}$ ( $>3300 \%$ ) through the construction of The Palms, The World, The Universe, and Waterfront City developments, amongst others (Velegrinis \& Katodrytis 2015). Many of the plans were never realized, but the construction of The Palms alone (Figure 8A) has increased the linear extent of the 

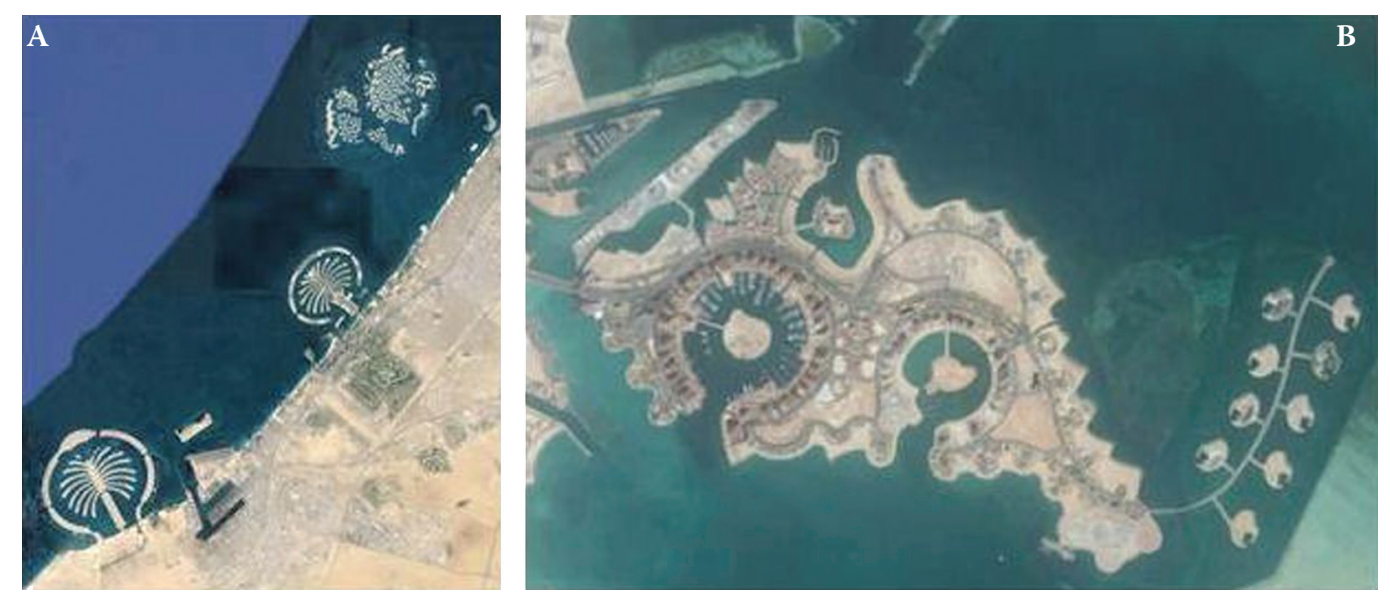

Figure 8 Examples of extreme cases of coastal development: (A) The Palm Islands and The World, Dubai; (B) the Pearl-Qatar, Doha. (Images from Google Earth.)

shoreline by 130\% (Burt et al. 2009, 2013). Doha and Bahrain have also constructed elaborate artificial islands; the Pearl-Qatar in Doha spans nearly 4 million $\mathrm{m}^{2}$ (Figure 8B), and the Durrat Al Bahrain, due for completion in 2015, is made up of an array of crescent-shaped islands (Velegrinis \& Katodrytis 2015). The construction of artificial islands to support infrastructure and people is not a new concept, but there is increasing concern about the environmental and political implications of these developments. At the time of writing, there was much media interest in construction of artificial islands by China in the Spratly Archipelago-a disputed group of more than 750 reefs, atolls, cays, and islands that straddles the maritime borders of China, Brunei, Malaysia, Taiwan, Philippines, and Vietnam-in the South China Sea. Other large-scale contentious projects were also in the planning for Penang and Johor, Malaysia, and Copenhagen, Denmark.

\section{Artificial structures as habitats: the diversity deficit and non-indigenous and pest species}

\section{The diversity deficit}

Artificial habitats have previously been considered as surrogates (albeit simplified) for natural habitats (Hawkins et al. 1983, Thompson et al. 2002, Bulleri \& Chapman 2004), although the recent surge of comparative studies repeatedly showed distinct differences in community structure and functioning between artificial structures and natural rocky reefs. These differences can be perceived as either positive or negative. On one hand, artificial structures have been reported to support increased diversity and abundance (Chou \& Lim 1986, Connell \& Glasby 1999, Wehkamp \& Fischer 2013, Munsch et al. 2014), provide habitat for unique taxa that are not found on natural rocky reefs (Chapman 2003, Bulleri \& Chapman 2004, Andersson et al. 2009), or support larger adult individuals (Kirk et al. 2007). On the other hand, artificial structures are more commonly considered to support a comparatively lower diversity (Moschella et al. 2005, Wilhelmsson \& Malm 2008, Pister 2009, Firth et al. 2013b, Aguilera et al. 2014, Munsch et al. 2014), particularly of rare and mobile species (Chapman 2003, 2006, Pister 2009), than adjacent natural hard substrata, resulting in a more homogeneous landscape (Lam et al. 2009). Associated organisms have also been shown to have lower genetic diversity (Fauvelot et al. 2009, Sammarco et al. 2012) or reduced reproductive output (Moreira 2006) or to be smaller in individual size (Moreira 2006, Diaz-Agras et al. 2010). 


\section{The influence of habitat complexity}

In natural environments, microhabitats (pits, crevices, and rock pools) are widely known to be important for biodiversity through the provision of refuges from abiotic and biotic stress (Fairweather 1988, Metaxas \& Scheibling 1993, Johnson et al. 1998, Firth et al. 2013b). The diversity deficit in artificial habitats may largely be explained by lower habitat complexity compared with natural habitats (e.g., Chapman 2003, Moschella et al. 2005, Loke et al. 2015). For example, engineered materials (e.g., quarried granite, concrete, steel) often have smoother surface texture than rocky-reef substrata, and structures tend to lack important microhabitats, such as rock pools, pits, and crevices.

Construction material and habitat complexity are repeatedly shown to be important determinants of community composition on artificial structures (e.g., Potts \& Hulbert 1995, Andersson et al. 2009, Bracewell et al. 2013, Coombes et al. 2015). For example, Connell \& Glasby (1999) found that urban structures in Sydney Harbour made from a range of materials supported very different epibiotic assemblages both between structural types and in comparison to natural reefs. Rilov \& Benayahu (1998) found that fish abundance and diversity around oil platform pillars were correlated with habitat complexity. Hunter \& Sayer (2009) reported up to three times higher abundances of fish and crustacean species using complex artificial reef modules, compared with simple modules and natural reefs.

\section{The influence of surface orientation and inclination}

The proliferation of artificial structures is leading to an increase in the proportion of steep and vertical-facing artificial substrata (Andersson et al. 2009, Chapman \& Underwood 2011, Firth et al. 2015b), and it is considered that the relative importance of orientation (i.e., north-south directionality) will increase with increasing substratum inclination (Firth et al. 2015b). Surface orientation, inclination, and shading may influence biodiversity on vertical or floating structures such as seawalls, pontoons, and pilings (Connell 1999, Glasby 1999, Knott et al. 2004, Perkol-Finkel et al. 2006, Langhamer et al. 2009, Chapman \& Underwood 2011, Firth et al. 2015b), leading to different emergent communities compared with natural reef habitats. On intertidal structures, a steeper shore profile can also lead to a reduction in habitat extent compared to natural shores, which may limit species diversity and abundance as a simple product of species-area relationships (Hawkins \& Hartnoll 1980).

\section{The influence of wave exposure}

Pister (2009) suggested that wave exposure might also contribute to differences in diversity between intertidal artificial and natural habitats in California (see also Davis et al. 2002). Indeed, where structures are introduced to high-energy environments (as coastal defences often are), conditions may favour colonization by certain species (e.g., filter-feeders and limpets: Moschella et al. 2005, Jonsson et al. 2006, Vaselli et al. 2008) but hinder settlement and post-settlement survival of others (e.g., some macroalgae: Jonsson et al. 2006; see also Mullineaux \& Garland 1993). Structures with both exposed and leeward sides may present 'unnatural' sheltered habitat along exposed open coasts, which may favour algal-dominated communities (Southward \& Orton 1954, Jenkins et al. 1999, Jonsson et al. 2006, Burt et al. 2013). Further, high-disturbance regimes caused by wave energy and sand scouring around structures (Moschella et al. 2005, Burcharth et al. 2007, Firth et al. 2014b) may prevent communities from developing beyond early successional stages. Artificial structures often support assemblages more typical of rocky reefs jutting out from high-energy sandy beaches (Bally et al. 1984) that tend to be dominated by ephemeral early successional species. 


\section{The influence of structure age}

Finally, the age of structures at the time of assessment may be an important determinant of how similar colonizing communities are to natural mature reef communities. Age has been shown to explain considerable variation in community structure in artificial habitats (Knott et al. 2004, Sammarco et al. 2004, Perkol-Finkel et al. 2005, Pinn et al. 2005b, Burt et al. 2011, but see Wendt et al. 1989, Langhamer et al. 2009). Sheehan et al. (2013) recently highlighted the importance of appropriate monitoring of artificial structures over long timescales to effectively assess their ecological impact. At the Wave Hub site in the south of England, they observed recovery of opportunistic and fast-growing reef species on the cable rock armouring route within 2 years of construction. Slower-growing species were, however, still largely absent.

\section{Non-indigenous and pest species}

Non-indigenous species appear more prevalent on artificial structures than on adjacent natural habitat (see Mineur et al. 2012 for review). The introduction of novel artificial habitats in the marine environment may enable opportunistic and weedy species to take advantage of the unexploited bare substrata, particularly with increased surface inclination and shading (Chou 2006, Glasby et al. 2007, Dafforn et al. 2009, 2012, Marzinelli et al. 2009, 2011, Forrest et al. 2013, Simkanin et al. 2013).

In the Mediterranean, structures introducing 'unnatural' sheltered rocky habitat on the landward side of coastal defences along exposed open coasts can provide opportunities for non-indigenous algal species to colonize (e.g., Codium fragile ssp. tomentosoides and Caulerpa racemosa; Bulleri \& Airoldi 2005, Vaselli et al. 2008, Airoldi \& Bulleri 2011, Airoldi et al. 2015, but see Pister 2009), and this can be exacerbated by disturbance events such as structural maintenance or recreation (Airoldi et al. 2005b, Bulleri \& Airoldi 2005, Airoldi \& Bulleri 2011; see also Bracewell et al. 2013, Salomidi et al. 2013).

In Australia, the non-indigenous mussel Mytilus galloprovincialis planulatis frequently colonizes vertical seawalls in Sydney Harbour, where it can often occupy nearly all of the available space, overgrowing native assemblages (Chapman et al. 2005, Chapman \& Underwood 2011). In Europe, the invasive Australasian barnacle Austrominius (formerly Elminius) modestus colonizes structures, particularly on coastlines that are more sheltered and those in proximity to estuaries (Bracewell et al. 2012, 2013).

Structures in close proximity to transport infrastructure, such as ports and harbours, are particularly susceptible to colonization by non-indigenous species, particularly encrusting invertebrates and ascidians (Lambert \& Lambert 2003, Glasby et al. 2007, Dafforn et al. 2009, Griffith et al. 2009, Firth et al. 2011, Bishop et al. 2015). Non-indigenous species have also been recorded in high abundances on offshore structures such as oil and gas platforms (Fenner and Banks 2004, Sammarco et al. 2004, 2010, Page et al. 2006, Yeo et al. 2010) and wind power turbines (Wilhelmsson \& Malm 2008).

Artificial structures associated with aquaculture (e.g., oyster trestles, mussel ropes) can provide substratum for the attachment of non-indigenous species (e.g., Minchin 2007, Rius et al. 2011, Morgan \& Richardson 2012, Nunn 2014, Pochon et al. 2015). Negative effects include direct impacts on cultured species (e.g., smothering, competition for space and food); deterioration of farm infrastructure (immersed structures such as cages, netting, and pontoons); and effects on natural ecosystem functioning of adjacent areas (Fitridge et al. 2012, Fletcher et al. 2013).

\section{Disentangling 'natural' spread and facilitation by artificial structures}

It has been suggested that artificial structures may provide opportunities for assisted migration of species at risk from climate change (Hoegh-Guldberg et al. 2008). The distribution of species is 
continually changing as fluctuations and trends in sea and air temperatures alter the suitability of a habitat (Parmesan \& Yohe 2003, Harley et al. 2006, Sunday et al. 2012, Bates et al. 2014, 2015). The velocity of climate change (sensu Loarie et al. 2009) is dependent on local or regional features of the environment, some of which can act as barriers to species movement (Damschen et al. 2006, Burrows et al. 2011, Poloczanska et al. 2013), as well as changes in the physiological performance of species (and in particular their free-living early life-history stages) as their environment changes (sensu proximate responses; Harley et al. 2006).

There is increasing evidence that artificial structures are facilitating the spread of species by allowing these barriers to be overcome (Herbert et al. 2003, Sammarco et al. 2012), increasing the rate of spread of some species (Hawkins et al. 2008, 2009) and leading to biotic homogenization. While it is becoming increasingly evident that artificial structures provide novel habitat for species (especially non-indigenous species; see Mineur et al. 2012 for review), disentangling 'natural' changes in distribution patterns associated with climate change from those associated with the proliferation of artificial structures is challenging. Next, we attempt to disentangle changes in natural spread associated with climate change from those distributional shifts facilitated by artificial structures.

It is important to point out that the very definitions of native and non-indigenous species will be challenged by both climate change and ocean sprawl. Hellmann et al. (2008) noted that taxa that were previously considered 'invasive' might diminish in impact under climate change; conversely, previously native species may become invasive. The geographic distributions of many native species will shift, moving into areas where they were previously absent. In the examples that follow, we assign native or non-indigenous status to the species, based on that identified by the relevant authors. Care must be taken, and we advise only using the term non-indigenous species for those taxa whose origin is another biogeographic province. Thus a species whose range is moving polewards is indigenous to that region - and might well have been present in that region before, during previous warm interglacial periods. Many species have shown polewards spread from refugia following the last glacial maximum (Maggs et al. 2008, Searle et al. 2009, McDevitt et al. 2010).

\section{Range changes of non-indigenous species associated with artificial structures}

Artificial structures have been widely reported to facilitate the spread of non-indigenous species in the marine environment (Tyrrell \& Byers 2007, Ruiz et al. 2009, Sheehy \& Vik 2010, Mineur et al. 2012, Airoldi et al. 2015). For example, in South Africa, the number of reported non-indigenous species has risen dramatically in recent years (see Griffiths et al. 1992, Mead et al. 2011 for reviews). Small harbours with yachts commonly support more non-indigenous fouling species than other harbours (Peters et al. 2014). In a study encompassing a range of biogeographic provinces, Rius et al. (2014) found that increases and expansions of non-indigenous species distributions were uncorrelated with levels of boat traffic but concurrent with increases in sea-surface temperature (SST), suggesting that climate change fostered the spread and abundance of non-indigenous tunicates across multiple spatial scales.

In the United States, the mussel Perna viridis is a recent invader to the south-eastern states, where it can be found overgrowing the native oyster Crassostrea virginica (Baker et al. 2007) or attached to any kind of artificial hard structure available (pier pilings, pontoons, sea walls). This species is susceptible to winter mortality events linked to extremely cold air temperatures (Firth et al. 2011, Urian et al. 2011). The invasive range of $P$. viridis is spreading eastward along the Florida Panhandle and northward towards South Carolina (Benson 2010, Crickenberger \& Moran 2013, Spinuzzi et al. 2013). This region of the United States is characterized by sedimentary habitats and the spread of this species has been facilitated by artificial structures. In the case of $P$. viridis, it is 
considered that cold winters are limiting the northward range expansion in the short term, but it is expected that long-term warming will ultimately facilitate further spread, providing hard substrata are available (i.e., artificial structures; Firth et al. 2011).

In addition to non-indigenous species, artificial structures have been implicated in the increase and spread of pest and harmful species. Jellyfish blooms have been reported to be increasing in intensity and frequency worldwide (Condon et al. 2013, Graham et al. 2014, Pitt \& Lucas 2014) and have been linked to growth in marine shipping and aquaculture and the proliferation of artificial structures providing habitat for the polyps (Lo et al. 2008, Ishii \& Katsukoshi 2010, Duarte et al. 2012). In addition, the cold-water toxic dinoflagellate Alexandrium catenella exhibited multiple blooms along the Spanish Mediterranean coastline in the 1990s (Vila et al. 2001); this expansion was attributed to newly constructed harbours. Similarly, oil platforms in the Gulf of Mexico were considered responsible for the spread of cigatuera (human disease acquired by consuming finfish containing ciguatoxins) due to the creation of new suitable habitat for the dinoflagellate Gambierdiscus toxicus — the source of the ciguatoxins (Villareal et al. 2007).

\section{Range changes of non-indigenous species associated with climate change}

It has long been claimed that global climate change is linked to the increasing success of nonindigenous species (Dukes \& Mooney 1999, Stachowicz et al. 2002a, Sorte et al. 2010), with associated negative impacts on native biodiversity (Vitousek et al. 1997, Sala et al. 2000; see review by Occhipinti-Ambrogi 2007). A global meta-analysis did not find a global increase in invasive species distributions following climate and land use changes (Bellard et al. 2013), but as this study combined both climate and land use changes for marine, aquatic, and terrestrial taxa, it is difficult to disentangle any specific patterns for individual groups (see Lyons et al. 2015).

Climate-driven changes may affect both local dispersal mechanisms, due to the alteration of current patterns, and competitive interactions between non-indigenous species and native species, due to the onset of new thermal optima. The effects of warming climate are primarily a cause for physiological stress, which acts more strongly on species already near their tolerance limit (Laubier 2001). Extreme climatic events such as heatwaves and cold waves can cause mass mortalities (Cerrano et al. 2000, Garrabou et al. 2001, Petes et al. 2007, Firth \& Williams 2009, Firth et al. 2011), and storm events can cause dislodgement of benthic organisms (Denny et al. 2009, Airoldi \& Bulleri 2011), resulting in bare space for invasion by non-indigenous species (reviewed in Diez et al. 2012).

\section{Range changes of native species associated with artificial structures}

Climate change-induced range shifts are complicated by additional non-climatic factors operating at smaller spatial scales, including habitat suitability, fragmentation, hydrodynamics, and deployment of artificial structures, which provide stepping stones in regions of unsuitable natural habitat and can bridge barriers to natural larval dispersal (Gaylord \& Gaines 2000, Burrows et al. 2008, Keith et al. 2011, Sammarco et al. 2012, Firth et al. 2013a, Adams et al. 2014). Here we focus on the potential for artificial structures to potentially interact with climate change, thus exacerbating the rate of spread of species by acting as stepping stones to natural dispersal.

The proliferation of oil and gas platforms in the Gulf of Mexico has been linked with the range extensions of coral and fish species (Rooker et al. 1997, Sammarco et al. 2004, Atchison et al. 2008). Sammarco et al. (2012) investigated the genetic connectivity of corals on oil platforms in the northern Gulf of Mexico. Genetic connectivity was highest on platforms near the Flower Garden Banks (the only natural coral reef in the area) and decreased with distance away from the banks. Their study also revealed two genetically distinct populations either side of the Mississippi River, indicating that the river represents a formidable barrier to larval dispersal. Such an increase in gene flow can reduce genetic diversity by removing barriers for dispersal, with a significant negative effect 
on the potential adaptive capacity of a species and, ultimately, on evolutionary processes (Palumbi 2003, Airoldi et al. 2005a).

The spread of non-indigenous species is becoming increasingly linked to human-mediated transport of organisms, in particular associated with the aquaculture industry. In contrast, there are few examples of native species range expansions being facilitated by the same mechanism. One example is the northward extension of the native infaunal polychaete Diopatra biscayensis beyond a regional biogeographic boundary in northern France. Woodin et al. (2014) suggested that the placement of aquaculture structures provided the most likely mechanism for the bridging of a regional biogeographic boundary. It is expected that future warming will prompt the further northward extension of populations (Wethey et al. 2011), illustrating how climate change and artificial structures can act synergistically.

The proliferation of artificial breakwaters along the Belgian coastline is thought to have facilitated the range extension of the Boreal periwinkle Littorina saxatilis (Johannesson \& Warmoes 1990). Interestingly, this species lacks a planktonic larval stage, and it is assumed that the continuous nature of the structures, rather than larval dispersal or climate change, has facilitated this particular range extension. In the United Kingdom, artificial coastal defence structures are becoming increasingly common along the southern coast of England. Historically, Portland Bill (Dorset) and St. Catherine's Point on the Isle of Wight have acted as natural barriers to dispersal (Crisp \& Southward 1958), but in recent years, populations of many southern warm-adapted invertebrate species, such as Perforatus (formerly Balanus) perforatus, Gibbula umbilicalis, Patella ulyssiponensis, and Melaraphe neritoides, have managed to breach these hydrographic barriers (Herbert et al. 2003, Mieszkowska et al. 2006, Herbert et al. 2007, Keith et al. 2011). It has been suggested that artificial coastal defence structures and marinas have acted as stepping stones in this instance, 'artificially' facilitating an extension in range of these species (Moschella et al. 2005, Hawkins et al. 2008).

The construction of artificial structures can also infill the gaps in species distributions by effectively creating corridors to dispersal between previously unconnected areas. In North Wales, the reef-forming polychaete worm Sabellaria alveolata has successfully colonized a network of coastal defence structures, bridging a historic gap in distribution of natural rocky shore populations that were previously separated by about $35 \mathrm{~km}$ (Firth et al. 2015a). The same study also documented population increases within the geographic region, suggesting that the species may also be benefitting from recent warming. The authors highlighted the difficulties in disentangling the effects of the proliferation of artificial structures from climate-driven warming. This spread has most likely come from S. alveolata populations on the coast of north-western England, showing the importance of artificial structures in consolidation of fragmented populations at range edges.

\section{Range changes of native species associated with climate change}

Evidence for changes in the latitudinal location of one or more range limits has been recorded for many marine species across the globe since the onset of the current period of climate warming in the 1980s. The general pattern has been a shift in "leading' range edges expanding polewards towards AU/PE: Is "Dohigher latitudes and cooler environmental temperature regimes and a contraction of the "trailing' wards" correct? low-latitude range edge away from warming temperatures. These changes have been observed in $\begin{aligned} & \text { tout? } \\ & \text { out? }\end{aligned}$ global meta-analyses for pelagic fish (MacNeil et al. 2010, Sunday et al. 2012), plankton (Edwards et al. 2014), and marine species in general (Sorte et al. 2010, Poloczanska et al. 2013).

\section{Leading edges}

The leading edge is the range limit that is expanding as new populations become established at locations where previously none existed. 'Hotspots' of range shifts include the biogeographic break point between Boreal and Lusitanian regions in the north-eastern Atlantic, where leading range 
edges of Lusitanian species from warmer, low-latitude origins are extending into higher latitudes where environmental temperatures have increased sufficiently to facilitate survival and reproduction (Burrows et al. 2011). Several range extensions have been recorded around the UK coastline, many reported by the Marine Biological Association of the UK MarClim project, which has documented range shifts for a wide range of rocky intertidal invertebrates and macroalgae since the mid1980s (summarized in Helmuth et al. 2006, Hawkins et al. 2008, 2009, Mieszkowska et al. 2014). The leading range edges of Lusitanian gastropods (Patella depressa, Phorcus lineatus, and Gibbula umbilicalis); barnacles (Chthamalus stellatus, C. montagui, and Perforatus perforatus); and kelp (Laminaria ochroleuca) have shifted northward around the Atlantic coastline and north-east along the English Channel coastline (Herbert et al. 2003, Mieszkowska et al. 2006, 2007, Smale et al. 2014, Yesson et al. 2015). These shifts in range have implications for biotic interactions and community structure and functioning in the 'receiving' environment (e.g., Moore et al. 2007a,b, Blight \& Thompson 2008, Poloczanska et al. 2008, Firth et al. 2009). The extent of range shifts, however, is species specific, with some species moving much less than others (e.g., C. montagui and C. stellatus in the English Channel; Herbert et al. 2007, 2009), most likely related to the duration of their freeliving planktonic life-history stage (Shanks 2009). As such, the potential for a species to breach a hydrographic barrier is very much dependent on its particular early life-history characteristics.

Outside the United Kingdom, evidence of range shifts is mostly limited to recent decades, stemming from the growing awareness of the need for datasets of broad spatial and temporal coverage to track and predict impacts of global environmental change (Lima et al. 2006, 2007a,b, Blanchette et al. 2008, Broitman et al. 2008). Nevertheless, significant range shifts have been observed. For instance, polewards shifts at the leading edge are reported along the Pacific coastline of the United States for the gastropod Kelletia kelletii (Zacherl et al. 2003). In the temperate zone of Australia, there are many endemic species due to its geographic isolation from other climatically similar regions (Poore 2001), and range extensions have been reported for a number of species. For example, along the eastern coast, the urchin Centrostephanus rodgersii (Ling 2008, Ling et al. 2009) and the intertidal barnacle Austromegabalanus nigrescens have shifted considerable distances from the Australian mainland to Tasmania due to the intensification of the East Australia Current and resulting warmer sea temperatures (Pitt et al. 2010, Johnson et al. 2011). There have also been marked increases in abundance of the warm-water spiny lobster Jasus edwardsii and the abalone Haliotis rubra (Poloczanska et al. 2011).

Some evidence of range shifts is, however, equivocal in part due to localized warming trends or challenges in predicting the direction of shifts. For example, a study of 10 intertidal species along the Chilean coast involving the comparison of field studies to museum records did not find pervasive range shifts between the mid-1900s and 2000 (Rivadeneira \& Fernández 2005). This was attributed to differential warming trends along the Chilean coast during this time. Similarly, a study of over 80 intertidal species in eastern Australia comparing data from the 1940s and 1950s with current distributions indicated little change (Poloczanska et al. 2011). In New Zealand, there have been few large-scale studies. However, those that exist suggest fragmented distributions and complex evolutionary histories, which makes the detection and prediction of climate-driven distribution changes problematic (Goldstien et al. 2006, Mieszkowska \& Lundquist 2011).

\section{Trailing edges}

Far less information exists on the fate of lower-latitude range limits, even for well-studied taxa. Where assessments have been undertaken, shifts in trailing range edges have been observed. The tortoiseshell limpet Testudinalia testudinalis and the brown macroalga Alaria esculenta (Simkanin et al. 2005, Mieszkowska et al. 2006) have shown retractions in their southern extent as well as decreases in abundance in Britain and Europe during the last few decades. Some retractions have been over significant geographic distances. For example, the trailing edge of the blue mussel Mytilus edulis has retreated more than $350 \mathrm{~km}$ to higher latitudes in response to warmer summers related 
to climate change in the North Carolina region of the United States over the past few decades (Jones et al. 2009, 2010). In contrast, there has been an extension in range of the Boreal barnacle Semibalanus balanoides at the Boreal/Lusitanian breakpoint region along the Biscay coast of France following the extremely cold winter of 2009-2010 (Wethey et al. 2011, Jones et al. 2012). In marine macroalgae, fewer changes in distribution have been detected than for animals. This could be due in part to difficulties in monitoring subtidal species over large spatial scales. The lower dispersal capability of some macroalgae may also limit the ability of species to colonize new habitats (Araújo et al. 2011, Moalic et al. 2011).

Evidence of range shifts can be influenced by the phylogeographic history of the species in question. Lima et al. (2007a) showed a prevalence of shifts in 'warm-water' species (leading edge) in comparison to 'cold-water' counterparts (trailing edge). In those instances, there have been significant alterations in the range edge. Surveys of macroalgal distributions along the coast of Portugal during the 1950s, 1960s (Ardre 1970, 1971), and 2000s (Lima et al. 2007a) identified about 120 conspicuous species that have shown significant alterations in the location of a range edge. A greater number of warm-water species showed northward extensions in latitudinal range limits, with significant correlations between distributional shifts and mean annual inshore SST since 1941 (Lemos \& Pires 2004). Species classified as cold water in origin displayed both northward and southward shifts with no significant change when considered as a group.

\section{Mechanisms affecting distribution patterns: climate-driven changes in dispersal capacity and enhanced connectivity}

Climate envelope models can be used to forecast where a species could potentially survive (Berry et al. 2002, Araújo et al. 2004, Thuiller 2004) as temperature is often the ultimate factor setting species distributions (e.g., Tomanek \& Somero 1999, Perry et al. 2005). Direct limitation of dispersal capacity by coastal topographic features such as headlands or islands, coupled with the hydrodynamics of nearshore waters, such as residual currents, tidal streams, and frontal systems, is often the proximate factor setting distributional limits (Crisp \& Southward 1958, Gaylord \& Gaines 2000, Keith et al. 2011). Interannual variability in climate conditions (e.g., extreme weather events) may lead to changes in dispersal or survivorship in a given year (Occhipinti-Ambrogi 2007, Cheung et al. 2009, Aprahamian et al. 2010, Firth et al. 2011), and species are likely to 'track' suitable conditions for survival (Burrows et al. 2011). Depending on larval 'fitness' under those conditions, the absence of suitable habitat, which could include artificial structures, may make the distance between patches of suitable habitat too great for successful recruitment or establishment of a viable population. Alternatively, their introduction could play a role in providing stepping stones for dispersal (Bulleri \& Airoldi 2005, Glasby et al. 2007, Miller et al. 2013), leading to biotic homogenization.

Disentangling the relative importance of climate change as an ultimate driver from the proximate role of artificial structures in enabling range extensions is challenging. Many species display a biphasic life history, in which they utilize a free-living (planktonic) larval life-history stage as a means of dispersal prior to metamorphosis to an often-sessile adult form. This larval life-history stage can last from minutes (e.g., Thorson 1946) to days (e.g., Ryland et al. 2000), to weeks (e.g., Ayata et al. 2009), or to months (e.g., Shanks 2009), the duration of which-referred to as the planktonic larval duration - greatly influences the dispersive capacity of a species.

Larval development can be broadly classified into one of three strategies: direct development, lecithotrophy, or planktotrophy, with dispersal capability being least in direct developers and greatest in planktic developers (Thorson 1950, Shanks 2009). Despite marked differences in strategies, there is evidence of increased fragmentation of natural habitats and reduced connectivity between populations, especially for species with short planktonic durations (Hughes et al. 2005b, Trakhtenbrot et al. 2005). Under current climate change scenarios, connectivity is predicted to 
further decrease as increased sea temperatures and ocean acidification negatively affect reproductive success, development, and growth (Petes et al. 2007, Lika et al. 2011).

For many species, increased temperature leads to faster rates of development of larval, juvenile, and adult forms (Manush et al. 2006, Aprahamian et al. 2010, Mueller et al. 2015), reducing their exposure to ocean currents for transport (Shanks 2009). A meta-analysis by O'Connor et al. (2007) highlighted the general reduction in development times as temperatures increase for a range of phyla. While useful, this analysis was perhaps overly simplistic, in that it inferred a linear relationship between planktonic larval duration and dispersal distance, predicting an average increase in dispersal distance of about $3.1 \mathrm{~km}$ with each additional day in the plankton. However, as highlighted by Shanks (2009), while in many instances larval duration is significantly correlated with dispersal distance, there are many exceptions, with individuals travelling much shorter distances than predicted (Siegel et al. 2003).

\section{Artificial structures offsetting reduced dispersal potential}

Predicting dispersal is challenging, and the use of 1-dimensional estimates of spread (e.g., $\mathrm{km} \mathrm{y}^{-1}$ ) may not capture range shifts effectively (Mineur et al. 2010). Certainly, there appears to be an increase in rates of species spread associated with human vectors in recent years (Mineur et al. 2010, 2012), perhaps related to the proliferation of artificial structures (both onshore and offshore) that has altered the connectivity of marine populations (Saura et al. 2013, Adams et al. 2014). In most instances, structures are built in areas that would otherwise be sedimentary, on one hand causing the fragmentation and loss of existing natural sedimentary habitats and on the other creating stepping stones or corridors for hard-bottom species (Dethier et al. 2003, Airoldi et al. 2005a, 2015, Bulleri \& Airoldi 2005, Bulleri \& Chapman 2010, Miller et al. 2013).

To date, the potential interactions between climate change and ocean sprawl on the connectivity of marine populations are poorly understood. Any increase in connectivity arising from the introduction of artificial structures could be a cost-effective way of enhancing the conservation of threatened species and habitats, for example, by providing new dispersal routes that facilitate migrations in response to climate change (Thomas 2011). There could be severe drawbacks, however, as these novel habitats can act as barriers or partial filters to the regional-scale dispersal of coastal species, disproportionately favouring non-indigenous over native species (Tyrrell \& Byers 2007, Airoldi \& Bulleri 2011, Airoldi et al. 2015).

The increased prevalence of artificial structures may therefore not be desirable in terms of increased risk of spread of potentially harmful non-indigenous species. Certainly, artificial structures have been implicated in the increase and spread of pest species (see previous discussion). Understanding the factors that facilitate or prevent the migration of species through networks of structures would allow improved decision-making about the size and spacing of artificial structures in marine seascapes to simultaneously preserve fundamental ecological processes, enhance conservation of native biodiversity, and achieve economic and social goals. To that end, accurate descriptions of dispersal distance both today and forecast for the future are needed to underpin the management and use of marine space.

\section{Understanding the mechanisms of range extension: a modelling approach}

Biophysical modelling has become an increasingly widely used tool for predicting dispersal and evaluating mechanisms used by species to facilitate their dispersal. In brief, the approach simulates the dispersal of planktonic species by coupling a physical (hydrodynamic) description of the environment with a description or mimicry of biological traits or behaviours (e.g., vertical swimming) in response to a specific cue or cues, such as temperature, halocline, or pycnocline (e.g., North et al. 

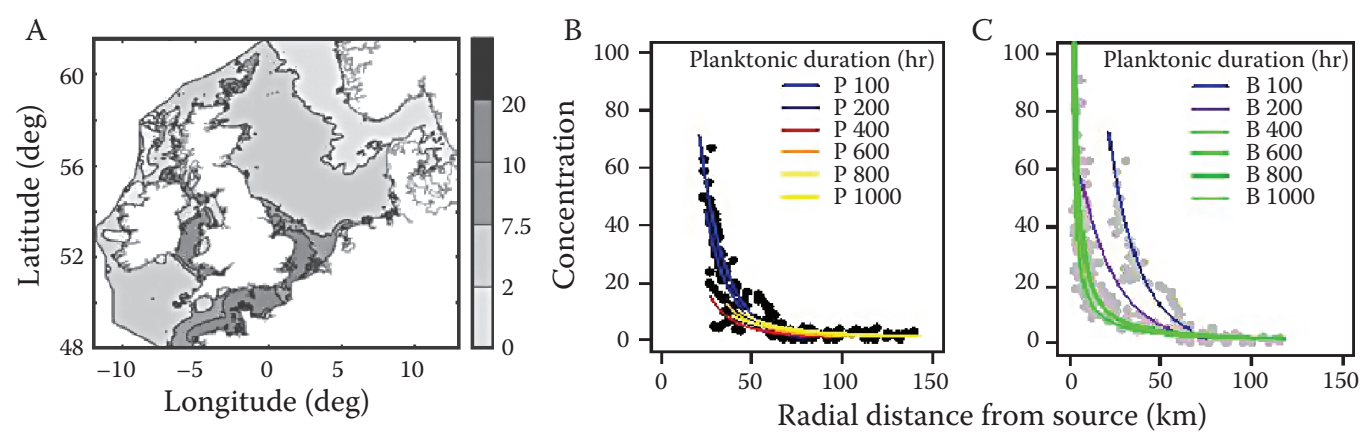

Figure 9 (A) The average tidal excursion distance $(\mathrm{km})$ per semi-diurnal tidal cycle (M2) and generalized dispersal kernel estimates (larval concentration $\mathrm{km}^{-2}$ ) for a range of planktonic larval durations (h) from a source population predicted by (B) physical forcing only and (C) physical forcing plus biological traits. In (B) and $(\mathrm{C})$, the same colour regression line indicates no significant difference (at $P=.05$ ) in the dispersal kernel estimate within or between (B) physical and (C) biophysical models. (Figure 9A was redrawn from Polton et al. 2014 with permission from Taylor \& Francis Ltd., http://www.tandfonline.com/toc/ggaf20/current.)

2008, Lloyd et al. 2012). Simulations can be run to examine the effects of climate change on performance of individuals of a species (i.e., planktonic larval duration) in a spatially resolved context. When coupled with data on the location of artificial structures, the interactions between these structures and climate change in facilitating species range extensions can be investigated.

The output of biophysical models is particularly useful to stakeholders, as the maps that are generated can be used to indicate areas of high or low connectivity (e.g., Figure 9). This information can support decision-making by managers to meet environmental objectives by identifying areas where dispersal potential is high, supporting natural spread, or conversely areas where dispersal potential is low, reducing the likelihood of invasive species spread. Predictions of larval retention can also aid forecasts of whether sites are likely to exhibit high or low recruitment rates (Gaines \& Bertness 1992, Swearer et al. 1999, Morgan et al. 2009, Morgan et al. 2014).

In a recent study, Adams et al. (2014) used a biophysical model to examine how changes in population connectivity may arise following the introduction of artificial structures in the marine environment. They showed that dispersal was driven by advection by wind forcing and boundary layer hydrodynamic processes, with propagules remaining close to the coast during dispersal. New habitat (i.e., the artificial structures) increased the theoretical population size, increased the likelihood of settlement, and facilitated access to previously inaccessible areas, particularly for short planktonic duration species (Adams et al. 2014). This type of analysis has the potential to shed light on sources of species as well as indicate possible locations for colonization.

Alternatively, the use of a physical model excluding any biological trait information may also provide valuable insights into areas of high and low connectivity (Largier 2003). For example, Polton (2014) characterized tidal excursion distances in and around the United Kingdom and Ireland (Figure 9A). This analysis revealed water retention time varied by an order of magnitude at local or subregional scales. If the physical environment alone can act as a suitable proxy for dispersal (Figure 9B), then this type of output could feasibly be used to highlight areas of larval retention (self-recruitment) or dispersal (connectivity) and support decision-making related, for example, to the placement of artificial structures to minimize connectivity. This approach, however, may not be suitable for species with longer planktonic larval durations. Certainly, a number of studies have highlighted the potential of larval behaviour to decouple dispersal predictions from estimates generated by physical (hydrodynamic) forcing alone (e.g., Shanks et al. 2003, Shanks 2009, Phelps et al. 2015), particularly for species with planktonic larval durations exceeding 10-100 hours (Shanks 2009, Knights et al. unpublished data; Figures 9B, 9C). Certainly, larval behaviour is often cited as 
playing a crucial role in determining dispersal distance and may well be responsible for the general failure of biophysical models to replicate patterns in nature (Jenkins 2005, Marshall et al. 2010).

\section{The problem: biotic homogenization}

Ocean sprawl - the proliferation of artificial structures — can be likened to urbanization (McKinney 2006) and is one of the most homogenizing human activities in the marine environment. Artificial structures are built to meet the relatively narrow needs of humans. They have traditionally been built with little consideration for the habitats that they replace and the communities that they inevitably support. In comparison to analogous hard-bottom natural habitats, these structures are more physically homogeneous at a range of spatial scales (Moschella et al. 2005, Burcharth et al. 2007). It is ultimately this physical homogenization of the environment that drives biotic homogenizationthe process by which species invasions and extinctions increase the genetic, taxonomic, or functional similarity among locations at regional and global scales (see review by Streftaris et al. 2005). Biotic homogenization is now considered a discrete component of the broader biodiversity crisis, with significant ecological, evolutionary, and social consequences.

The diversity resistance hypothesis states that diverse communities are highly competitive and therefore more resistant to invasion (Elton 1958, Levine \& D'Antonio 1999, Stachowicz et al. 2002b). This hypothesis has been tested and supported by many experimental studies in marine systems (Stachowicz et al. 1999, Stachowicz et al. 2002b, Arenas et al. 2006). Artificial structures are often characterized by lower species diversity and density than natural habitats (Bulleri \& Chapman 2004, Moschella et al. 2005, Moreira et al. 2007, Vaselli et al. 2008), and the establishment of invasive species on artificial structures could therefore be enhanced by the lower diversity and weaker competitive interactions. This might also be exacerbated by artificial structures often being subject to high levels of disturbance, which facilitate colonization by opportunistic species.

Predation (including grazing) is an important element of biotic resistance (Simkanin et al. 2013). Predator abundance can differ between natural and artificial habitats (Dumont et al. 2011, Forrest et al. 2013). Artificial structures, especially those that lack structural complexity or are separated from natural substrata, may have a lower abundance of mobile predators (Chapman 2003, Chapman \& Blockley 2009, Dumont et al. 2011) and therefore may act as refuges for the establishment of nonindigenous species. In natural habitats, where generalist predator numbers are greater, there may be increased resistance to invasion by newly arriving propagules (Forrest et al. 2013).

Understanding the factors and processes sustaining the biodiversity of artificial habitats and assessing their influences on establishment of non-indigenous species is therefore of key importance for our ability to predict and manage future pathways of invasion in coastal areas. Furthermore, the design of artificial structures in such a way that they enhance biodiversity is one management option that not only will increase the biotic value of the structure but also will increase the resilience of the assemblages on these structures to biotic invasion (Elton 1958, Stachowicz et al. 1999, Stachowicz et al. 2002b, Arenas et al. 2006). We discuss possible options for biodiversity management and enhancement in the following section.

\section{Managing artificial structures}

In the previous sections we illustrated how ocean sprawl or the global proliferation of artificial structures is occurring at an increasing rate along coastlines and in nearshore waters. There are significant environmental impacts associated with their construction, operation, and decommissioning (Dafforn et al. 2015b). Without planning and long-term management any structure that is placed in the sea can become a pollutant or hazard that contributes to the further degradation of the marine environment (Chou 1997). Here we consider options for managing marine development and provide recommendations for existing and future developments (Table 1). Our primary focus 


\section{OCEAN SPRAWL}

Table 1 Management options for existing structures, with selected examples from the published literature

\begin{tabular}{|c|c|c|c|c|}
\hline Approach & Description & $\begin{array}{l}\text { Summary of } \\
\text { major findings }\end{array}$ & Location & References \\
\hline \multicolumn{5}{|c|}{ Manipulating species } \\
\hline \multirow[t]{5}{*}{ Transplantation } & $\begin{array}{l}\text { Corals and sponges } \\
\text { transplanted on to } \\
\text { intertidal seawalls }\end{array}$ & $\begin{array}{l}\text { Higher survival of } \\
\text { massive and encrusting } \\
\text { species }\end{array}$ & Singapore & $\mathrm{Ng}$ et al. (2015) \\
\hline & $\begin{array}{l}\text { Corals transplanted on to } \\
\text { natural and artificial } \\
\text { reefs }\end{array}$ & $\begin{array}{l}\text { Higher survival and } \\
\text { growth on artificial reef }\end{array}$ & Israel & $\begin{array}{l}\text { Perkol-Finkel \& } \\
\text { Benayahu (2009) }\end{array}$ \\
\hline & $\begin{array}{l}\text { Kelp transplanted on to } \\
\text { subtidal pilings }\end{array}$ & $\begin{array}{l}\text { Showed that kelp can be } \\
\text { transplanted } \\
\text { successfully onto } \\
\text { artificial structures }\end{array}$ & Australia & Marzinelli et al. (2009) \\
\hline & $\begin{array}{l}\text { Canopy algae } \\
\text { transplanted on to } \\
\text { subtidal rock } \\
\text { breakwaters }\end{array}$ & $\begin{array}{l}75 \% \text { survival after } 6 \\
\text { months, indicating this } \\
\text { is a viable rehabilitation } \\
\text { option }\end{array}$ & Italy & Susini et al. (2007) \\
\hline & $\begin{array}{l}\text { Mussel cultivation in } \\
\text { disused docks }\end{array}$ & $\begin{array}{l}\text { Significant improvement } \\
\text { in water quality, } \\
\text { elimination of harmful } \\
\text { algae }\end{array}$ & $\begin{array}{l}\text { United } \\
\text { Kingdom }\end{array}$ & $\begin{array}{l}\text { Conlan et al. (1992), } \\
\text { Hawkins et al. } \\
\text { (1992a,b, 1999), Allen } \\
\text { \& Hawkins (1993), } \\
\text { Russell et al. (1983), } \\
\text { Allen et al. (1995), } \\
\text { Wilkinson et al. (1996) }\end{array}$ \\
\hline $\begin{array}{l}\text { Augmentative } \\
\text { biocontrol }\end{array}$ & $\begin{array}{l}\text { Use of native species to } \\
\text { prevent establishment } \\
\text { and spread of } \\
\text { non-natives on subtidal } \\
\text { artificial structures }\end{array}$ & $\begin{array}{l}\text { Settlement of non-natives } \\
\text { reduced by native } \\
\text { species predation and } \\
\text { space occupancy }\end{array}$ & New Zealand & $\begin{array}{l}\text { Atalah et al. (2013a,b, } \\
\text { 2014, 2015), Forrest } \\
\text { et al. (2013) }\end{array}$ \\
\hline Removal & $\begin{array}{l}\text { Chemical or physical } \\
\text { removal of non-native } \\
\text { species }\end{array}$ & $\begin{array}{l}\text { Results vary according to } \\
\text { location, method, and } \\
\text { species }\end{array}$ & Various & $\begin{array}{l}\text { Farnham \& Gareth- } \\
\text { Jones (1974), } \\
\text { Critchley et al. (1986), } \\
\text { Carver et al. (2003), } \\
\text { Hewitt et al. (2005), } \\
\text { Coutts \& Forrest } \\
\text { (2007), Forrest \& } \\
\text { Hopkins (2013), } \\
\text { McCann et al. (2013), } \\
\text { Aldred \& Clare (2014) }\end{array}$ \\
\hline \multicolumn{5}{|l|}{ Ecoengineering } \\
\hline \multirow[t]{2}{*}{ Tiles } & $\begin{array}{l}\text { Concrete 'artificial units } \\
\text { of habitat' (AUHs) } \\
\text { affixed to natural } \\
\text { intertidal rocky reef }\end{array}$ & $\begin{array}{l}\text { Deployed for research } \\
\text { purposes but } \\
\text { demonstrate habitat } \\
\text { provision by artificial } \\
\text { surfaces }\end{array}$ & Australia & Chapman et al. (2008) \\
\hline & $\begin{array}{l}\text { Pitted tiles affixed to } \\
\text { intertidal rock armour }\end{array}$ & $\begin{array}{l}\text { Many, smaller (14-mm) } \\
\text { pits supported more } \\
\text { species than fewer, } \\
\text { larger (32-mm) pits }\end{array}$ & $\begin{array}{l}\text { United } \\
\text { Kingdom }\end{array}$ & $\begin{array}{l}\text { Moschella et al. (2005), } \\
\text { Witt et al. (2012) }\end{array}$ \\
\hline
\end{tabular}

Continued 


\section{LOUISE B. FIRTH ET AL.}

Table 1 (Continued) Management options for existing structures, with selected examples from the published literature

\begin{tabular}{|c|c|c|c|c|}
\hline Approach & Description & $\begin{array}{l}\text { Summary of } \\
\text { major findings }\end{array}$ & Location & References \\
\hline & $\begin{array}{l}\text { Textured slabs ( } \pm \text { grooves } \\
\text { and pits) affixed to } \\
\text { intertidal rock armour }\end{array}$ & $\begin{array}{l}\text { Mussel and periwinkle } \\
\text { abundance higher on } \\
\text { pitted/grooved slabs }\end{array}$ & Netherlands & Borsje et al. (2011) \\
\hline & $\begin{array}{l}\text { Concrete tiles of varying } \\
\text { complexity affixed to } \\
\text { intertidal rock armour } \\
\text { (Figure 11B) }\end{array}$ & $\begin{array}{l}\text { Higher species richness } \\
\text { on more complex tiles }\end{array}$ & Singapore & Loke et al. (2014) \\
\hline & $\begin{array}{l}\text { Textured concrete tiles } \\
\text { affixed to intertidal rock }\end{array}$ & $\begin{array}{l}\text { Higher barnacle cover on } \\
\text { grooved compared to } \\
\text { smooth tiles }\end{array}$ & $\begin{array}{l}\text { United } \\
\text { Kingdom }\end{array}$ & Coombes et al. (2015) \\
\hline \multirow[t]{4}{*}{ Drilling } & $\begin{array}{l}\text { Pits drilled into intertidal } \\
\text { seawall }\end{array}$ & $\begin{array}{l}\text { Higher limpet abundance } \\
\text { in areas with } \\
\text { experimentally drilled } \\
\text { pits }\end{array}$ & Azores & Martins et al. (2010) \\
\hline & $\begin{array}{l}\text { Pits and grooves drilled } \\
\text { into intertidal seawall }\end{array}$ & $\begin{array}{l}\text { Smaller pits generally } \\
\text { supported more limpets } \\
\text { and chitons than larger } \\
\text { pits and grooves }\end{array}$ & Australia & $\begin{array}{l}\text { Chapman \& } \\
\text { Underwood (2011) }\end{array}$ \\
\hline & $\begin{array}{l}\text { Pits of different } \\
\text { diameters drilled into } \\
\text { intertidal concrete } \\
\text { wave-breaker units } \\
\text { (Figure 10A) }\end{array}$ & $\begin{array}{l}\text { Higher species richness } \\
\text { in pitted than control } \\
\text { areas; no pit diameter } \\
\text { effect }\end{array}$ & $\begin{array}{l}\text { United } \\
\text { Kingdom }\end{array}$ & Firth et al. (2014) \\
\hline & $\begin{array}{l}\text { Shallow }(5-\mathrm{cm}) \text { and deep } \\
(12-\mathrm{cm}) \text { rock pools } \\
\text { drilled into intertidal } \\
\text { rock armour } \\
\text { (Figure 10B) }\end{array}$ & $\begin{array}{l}\text { After } 6 \text { months, higher } \\
\text { taxon richness in } \\
\text { shallow pools; no } \\
\text { difference after } 18 \\
\text { months }\end{array}$ & $\begin{array}{l}\text { United } \\
\text { Kingdom }\end{array}$ & $\begin{array}{l}\text { Firth et al. (2014), } \\
\text { Evans et al. (2015) }\end{array}$ \\
\hline \multirow[t]{3}{*}{$\begin{array}{l}\text { Manipulate } \\
\text { concrete }\end{array}$} & $\begin{array}{l}\text { Rock pools created in } \\
\text { poured concrete on } \\
\text { intertidal causeway } \\
\text { (Figure 10D) }\end{array}$ & $\begin{array}{l}\text { Lower pools supported } \\
\text { greater diversity than } \\
\text { upper pools; lower- } \\
\text { shore kelp found in } \\
\text { upper pools; sheltered } \\
\text { pools filled up with } \\
\text { sediment }\end{array}$ & Ireland & Firth (unpublished) \\
\hline & $\begin{array}{l}\text { Pools created in concrete } \\
\text { on intertidal groyne } \\
\text { (Figure 10C) }\end{array}$ & $\begin{array}{l}\text { Important habitat- } \\
\text { forming coralline algal } \\
\text { germlings found in } \\
\text { pools }\end{array}$ & $\begin{array}{l}\text { United } \\
\text { Kingdom }\end{array}$ & Firth et al. (2014) \\
\hline & $\begin{array}{l}\text { Pits, grooves, and } \\
\text { recesses in concrete } \\
\text { between blocks of } \\
\text { intertidal seawall } \\
\text { (Figure 11A) }\end{array}$ & $\begin{array}{l}\text { Recesses supported } \\
\text { greater species richness } \\
\text { than other treatments }\end{array}$ & $\begin{array}{l}\text { United } \\
\text { Kingdom }\end{array}$ & Firth et al. (2014) \\
\hline
\end{tabular}




\section{OCEAN SPRAWL}

Table 1 (Continued) Management options for existing structures, with selected examples from the published literature

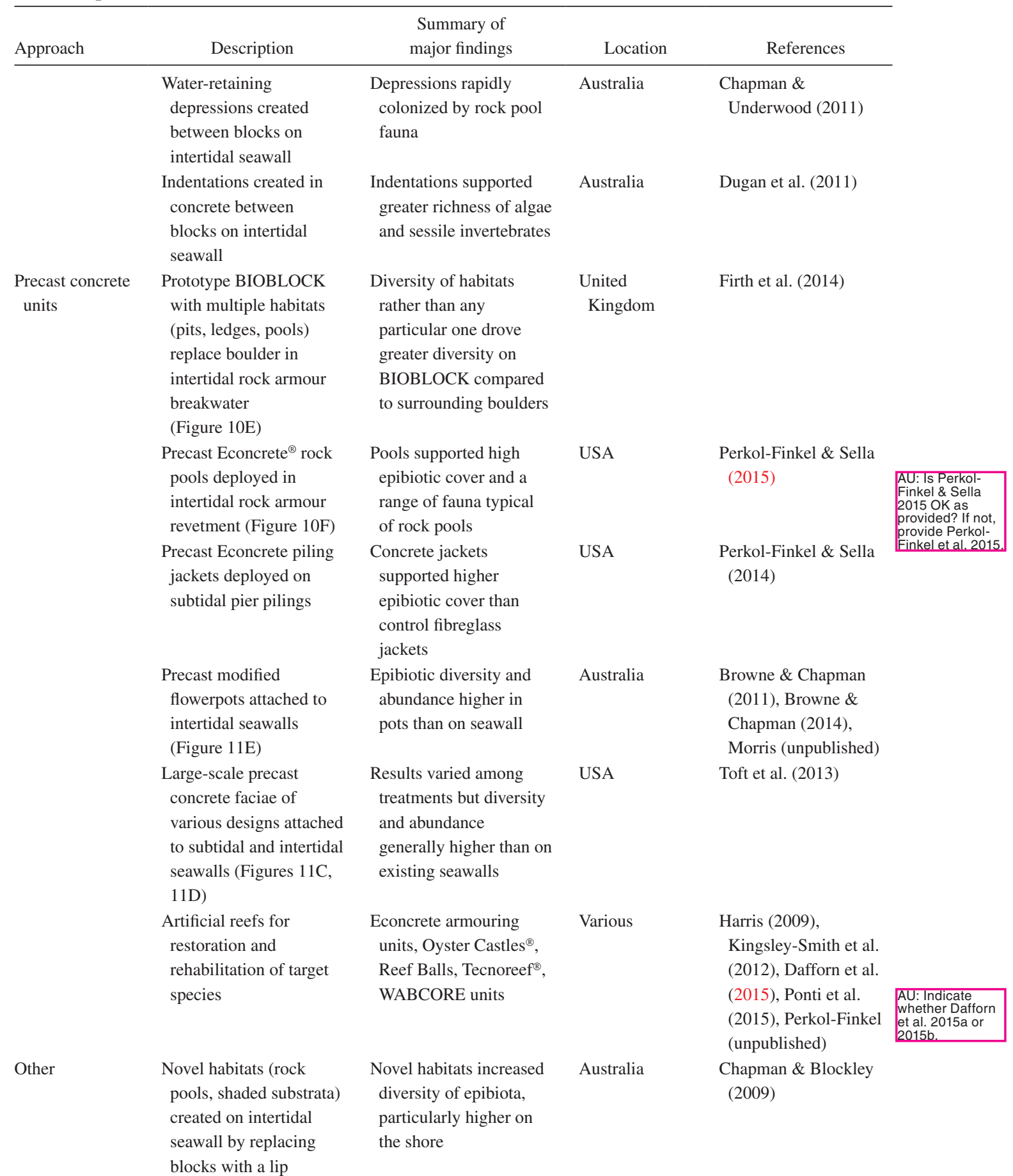




\section{LOUISE B. FIRTH ET AL.}

Table 1 (Continued) Management options for existing structures, with selected examples from the published literature

\begin{tabular}{|c|c|c|c|c|}
\hline Approach & Description & $\begin{array}{l}\text { Summary of } \\
\text { major findings }\end{array}$ & Location & References \\
\hline & $\begin{array}{l}\text { Rock piles (habitat } \\
\text { benches) constructed } \\
\text { adjacent to seawalls to } \\
\text { create shallow water }\end{array}$ & $\begin{array}{l}\text { Habitat benches } \\
\text { generally supported } \\
\text { greater abundance of } \\
\text { larval and juvenile fish } \\
\text { than control sites, also } \\
\text { diverse macroalgae }\end{array}$ & USA & Toft et al. (2013) \\
\hline & $\begin{array}{l}\text { Construction of rock } \\
\text { pools on top of } \\
\text { intertidal seawall }\end{array}$ & $\begin{array}{l}\text { Reports of debris } \\
\text { accumulation despite } \\
\text { large openings for tidal } \\
\text { flow }\end{array}$ & Australia & $\begin{array}{l}\text { Chapman \& } \\
\text { Underwood (2011) }\end{array}$ \\
\hline & $\begin{array}{l}\text { Gabion baskets } \\
\text { containing rocks of } \\
\text { different sizes }\end{array}$ & $\begin{array}{l}\text { No significant difference } \\
\text { in species richness but } \\
\text { total abundance greater } \\
\text { in small rock treatments }\end{array}$ & $\begin{array}{l}\text { United } \\
\text { Kingdom }\end{array}$ & Firth et al. (2014) \\
\hline & $\begin{array}{l}\text { Changing slope of } \\
\text { seawalls }\end{array}$ & $\begin{array}{l}\text { Abundance of mobile } \\
\text { organisms and } \\
\text { percentage cover of } \\
\text { sessile organisms higher } \\
\text { on vertical than } \\
\text { horizontal surfaces }\end{array}$ & Australia & $\begin{array}{l}\text { Chapman \& } \\
\text { Underwood (2011) }\end{array}$ \\
\hline & $\begin{array}{l}\text { Treating surfaces with } \\
\text { chemical cues to } \\
\text { promote recruitment }\end{array}$ & $\begin{array}{l}\text { Enhanced recruitment } \\
\text { around treated surfaces }\end{array}$ & Tunisia & $\begin{array}{l}\text { Rivera-Ingraham et al. } \\
\text { (2011) }\end{array}$ \\
\hline \multicolumn{5}{|c|}{ Site or structure designation } \\
\hline $\begin{array}{l}\text { Site of Special } \\
\text { Scientific } \\
\text { Interest (SSSI) }\end{array}$ & $\begin{array}{l}\text { Protected areas } \\
\text { designated for } \\
\text { biological, geological, } \\
\text { or physiographic } \\
\text { interest }\end{array}$ & $\begin{array}{l}\text { Network of intertidal } \\
\text { coastal defence } \\
\text { structures at Elmer } \\
\text { (United Kingdom) } \\
\text { proposed in } 2007 \text { as a } \\
\text { candidate SSSI due to } \\
\text { vegetated shingle and } \\
\text { organisms colonizing } \\
\text { the breakwaters; no } \\
\text { update since }\end{array}$ & $\begin{array}{l}\text { United } \\
\text { Kingdom }\end{array}$ & Burcharth et al. (2007) \\
\hline Rigs-to-Reefs & $\begin{array}{l}\text { Conversion of } \\
\text { decommissioned } \\
\text { offshore oil/gas rigs } \\
\text { into artificial reefs }\end{array}$ & $\begin{array}{l}\text { Applied widely in Gulf } \\
\text { of Mexico, but few data } \\
\text { to assess 'success' of } \\
\text { the practice or for } \\
\text { comparison of different } \\
\text { techniques }\end{array}$ & Gulf of Mexico & $\begin{array}{l}\text { Kaiser \& Pulsipher } \\
\text { (2005), Macreadie } \\
\text { et al. (2009), } \\
\text { Sammarco et al. } \\
\text { (2014) }\end{array}$ \\
\hline $\begin{array}{l}\text { Renewables-to- } \\
\text { Reefs }\end{array}$ & $\begin{array}{l}\text { Proposed conversion of } \\
\text { decommissioned wind } \\
\text { farms into artificial } \\
\text { reefs }\end{array}$ & $\begin{array}{l}\text { Recently suggested but } \\
\text { not yet implemented }\end{array}$ & Europe & Smyth et al. (2015) \\
\hline
\end{tabular}


Table 1 (Continued) Management options for existing structures, with selected examples from the published literature

\begin{tabular}{|c|c|c|c|c|}
\hline Approach & Description & $\begin{array}{l}\text { Summary of } \\
\text { major findings }\end{array}$ & Location & References \\
\hline $\begin{array}{l}\text { Artificial Marine } \\
\text { Micro Reserve } \\
\text { (AMMR) }\end{array}$ & $\begin{array}{l}\text { Proposed designation of } \\
\text { artificial structures as } \\
\text { refuges for endangered } \\
\text { species }\end{array}$ & $\begin{array}{l}\text { Network of AMMRs } \\
\text { proposed for the } \\
\text { western Mediterranean }\end{array}$ & $\begin{array}{l}\text { Western } \\
\text { Mediterranean }\end{array}$ & $\begin{array}{l}\text { García-Gómez et al. } \\
(2011,2014)\end{array}$ \\
\hline Marine reserves & $\begin{array}{l}\text { Areas designated to } \\
\text { protect natural or } \\
\text { cultural resources; } \\
\text { levels of human activity } \\
\text { (e.g., fishing, diving) } \\
\text { will be site specific }\end{array}$ & $\begin{array}{l}\text { Oil/gas platforms and } \\
\text { wind farms described as } \\
\text { de facto marine reserves } \\
\text { due to the 'artificial reef } \\
\text { effect' and exclusion of } \\
\text { fishing; official } \\
\text { designation could be } \\
\text { applied to these } \\
\text { locations during } \\
\text { operation }\end{array}$ & $\begin{array}{l}\text { Gulf of } \\
\text { Mexico, North } \\
\text { Sea }\end{array}$ & $\begin{array}{l}\text { Wilhelmsson et al. } \\
\text { (2006), Wilhelmsson } \\
\& \text { Malm (2008), Inger } \\
\text { et al. (2009), Wilson \& } \\
\text { Elliott (2009), Feary } \\
\text { et al. (2011), Reubens } \\
\text { et al. (2011, 2013), } \\
\text { Witt et al. (2012), } \\
\text { Ashley et al. (2014), } \\
\text { Pearce et al. (2014) }\end{array}$ \\
\hline
\end{tabular}

is the protection and promotion of native biodiversity with the ultimate goal of limiting undesirable biological homogenization. We identify management strategies for the cultivation of biodiverse communities through manipulations of target species, simple engineering interventions to create novel habitats, and designation of protective status. We also identify potential management strategies for future developments that offer opportunities to undertake an ecosystem approach to coastal defence by rehabilitating degraded natural habitats or working with stakeholders to create multifunctional structures. We outline how marine spatial planning can inform management decisions and briefly discuss how stakeholder engagement and perceptions may be used to inform future development plans.

\section{Management of existing structures}

Any hard structure placed in the marine environment will ultimately become fouled by sessile species (Wahl 1989, Dürr \& Watson 2010, Bracewell et al. 2013) and attract mobile organisms such as fish and crustaceans (Collins et al. 1994, Jensen 2002, Langhamer \& Wilhelmsson 2009). Occasionally, these colonizing communities can provide valuable ecosystem goods and services such as fisheries, carbon sequestration, and water purification, amongst others (Table 2; e.g., Langhamer \& Wilhelmsson 2009, Gkoumas et al. 2013, Layman et al. 2014), or be of conservation importance (Table 3; e.g., Gass and Roberts 2006, Martins et al. 2010, García-Gómez et al. 2014, Pearce et al. 2014, Firth et al. 2015a). In contrast, they can also support non-indigenous, pest, and harmful species (e.g., Bulleri \& Airoldi 2005, Villareal et al. 2007, Lo et al. 2008, Firth et al. 2011, Mineur et al. 2012). Of course, there are many situations where the desirable end point is no fouling community (e.g., ships, aquaculture), and an increasing number of antifouling technologies are being developed to prevent settlement of marine organisms (Whelan \& Regan 2006, Grozea \& Walker 2009, Chapman \& Regan 2012). With accumulating knowledge from best practice, simple and cost-effective measures can be used to achieve multiple ecosystem services, such as local biodiversity maintenance, provision of harvestable species, and protection of rare or endangered species.

\section{Species manipulations: removals and transplantations}

In comparison to terrestrial systems, the manipulation of organisms for purposes other than human consumption (aquaculture) is not well developed in marine systems. Here we outline some examples 


\section{LOUISE B. FIRTH ET AL.}
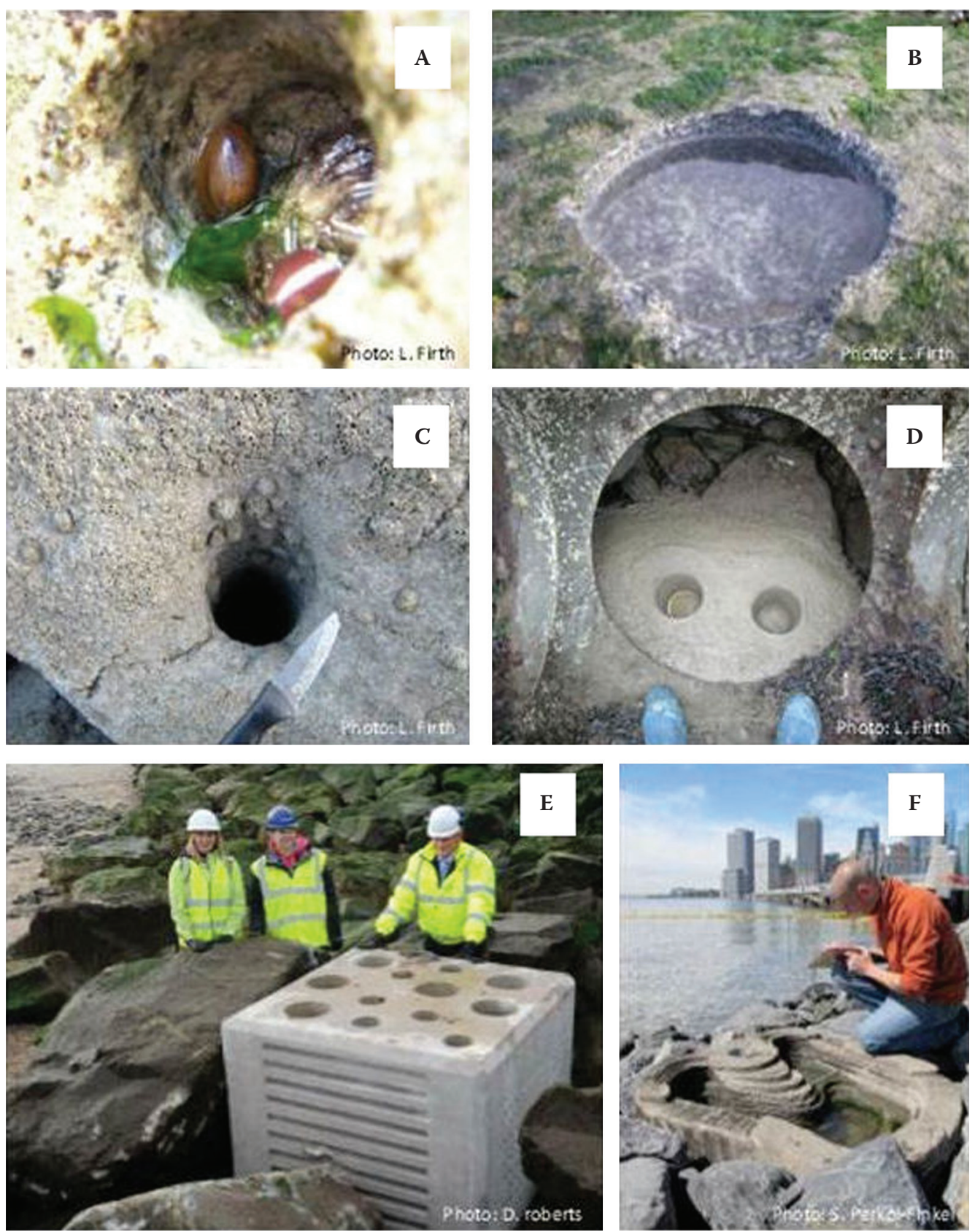

Figure 10 Variety of different ecological engineering techniques that can be incorporated into rock revet-AU/PE: Figures ment or riprap. (A) Pits drilled into wave-breaker units on Plymouth Breakwater, United Kingdom (Firth 10 and 11 are

AU: Indicate et al. 2014a or 2014b (NOTE: a and $b$ designations reversed from your original) four times nal) four times

Also, indicate if Also, indicate if the figures were taken from the source given

needed/in hand. 

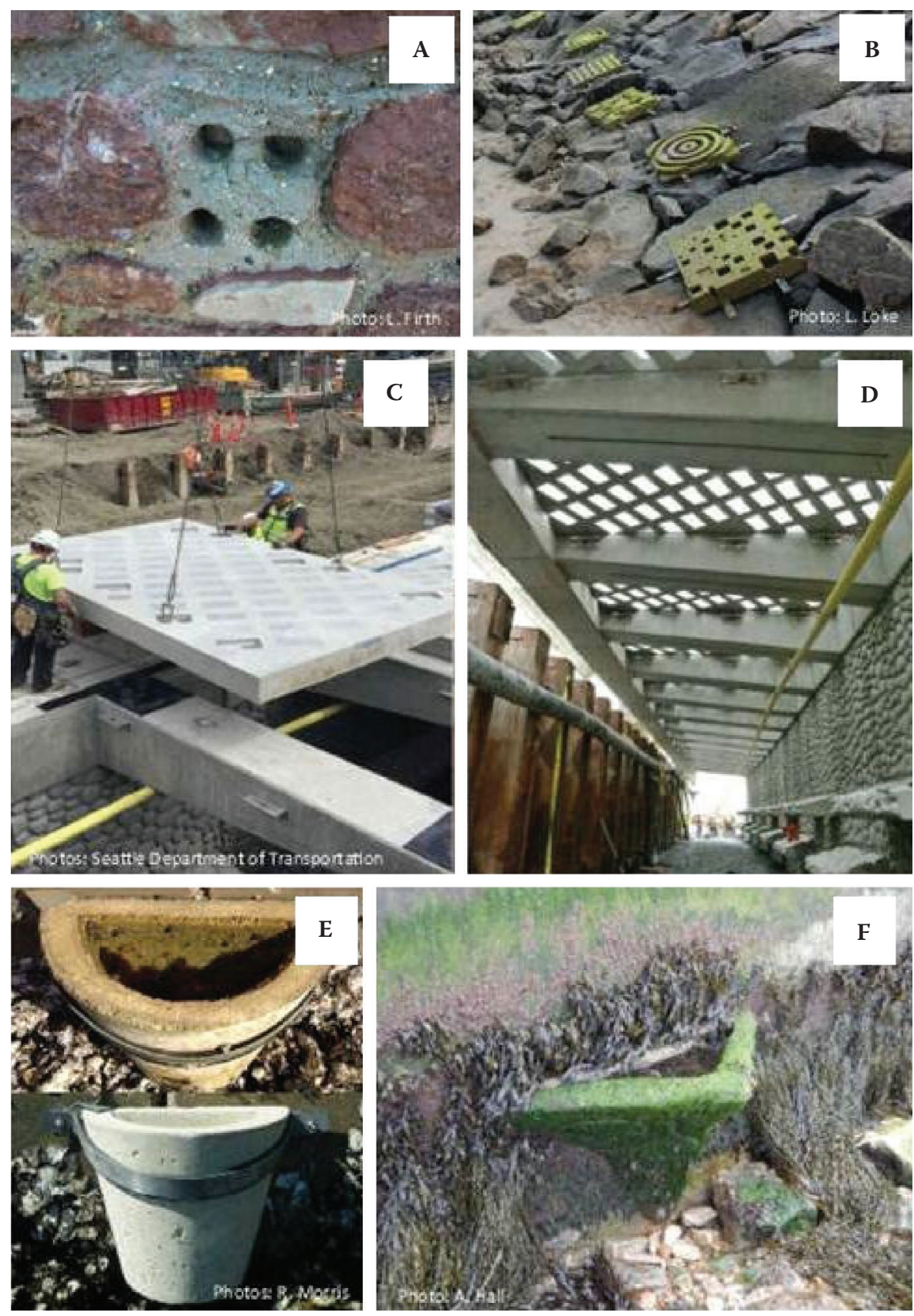

Figure 11 Variety of different ecological engineering techniques that can be incorporated onto seawalls. (A) Pits created by manipulating the concrete between bricks on a seawall, Shaldon, United Kingdom (Firth et al. 2014). (B) Precast habitat enhancement plates/tiles with different levels of complexity affixed to a seawall AU: Indicate in Pulau Hantu, Singapore (Loke et al. 2014, 2015). (C, D) Large-scale precast facia fronting urban seawalls in $\begin{aligned} & \text { whether Firth } \\ & \text { et al. } 2014 a\end{aligned}$ Seattle, Washington, USA (Toft et al. 2010, 2013). (E) Modified precast concrete flowerpots affixed to seawalls $\begin{aligned} & \text { or 2014b } \\ & \text { (NOTE: a an }\end{aligned}$ in Sydney, Australia (Browne \& Chapman 2011, 2014, Morris unpublished). (F) Precast concrete Vertipool b designations affixed to seawall on the Isle of Wight, United Kingdom (http://www.ecclestongeorge.co.uk). 


\section{LOUISE B. FIRTH ET AL.}

Table 2 Summary of organisms providing important ecosystem services associated with artificial structures

\begin{tabular}{cccc}
\hline Table 2 are OK. & \multicolumn{1}{c}{ Sescriptor } & Type of structure & References \\
\cline { 2 - 4 } Provisioning & $\begin{array}{c}\text { Commercially important } \\
\text { shellfish }\end{array}$ & Coastal defences & $\begin{array}{c}\text { Bacchiocchi \& Airoldi (2003), Devescovi \& } \\
\text { Iveša (2008), Jackson et al. (2008), Martins } \\
\text { et al. (2010), Dafforn et al. (2012) }\end{array}$ \\
& & & \\
& Commercially important & Oil and gas platforms, & Page et al. (1999), Toft et al. (2007, 2013), \\
& coastal defence structures & García-Gómez et al. (2014) \\
& Commercially important & Renewable energy & Langhamer \& Wilhelmsson (2009), Langhamer \\
& crustaceans & installations, coastal & et al. (2009), Wehkamp \& Fischer (2013), \\
& defence structures & Ashley et al. (2014), García-Gómez et al. (2014) \\
& Nursery habitat for fish & Renewable energy & Caine (1987), Able et al. (1998), Martin et al. \\
& and crustaceans & installations, coastal & (2005), Langhamer \& Wilhelmsson (2009), \\
& defence structures & Langhamer et al. (2009), Scyphers et al. (2015) \\
& Overexploited species & Coastal defences & Guerra-García et al. (2004), Devescovi \& Iveša
\end{tabular}

\section{Regulating Carbon sequestration \\ Potentially all structures} Water purification

Cultural

Potentially all structures

Coastal defences

Coastal defences
Artificial reefs, oil rigs, coastal defences

Coastal defences

Bait digging, shellfish gathering

Recreational fishing

Education (e.g., rock pooling)

Scientific research

Surfing

Primary production by algae and corals

Habitat provision for other species coastal defences

Coastal defences

Artificial reefs

Artificial surf reefs, multipurpose reefs

Potentially all structures

Potentially all structures
Chung et al. (2011), Gkoumas et al. (2013)

Allen et al. (1992, 1995), Allen \& Hawkins (1993), Wilkinson et al. (1996), Kohata et al. (2003), Hughes et al. (2005a), Layman et al. (2014)

Borsje et al. (2011), Firth et al. (2015a)

Lamberti \& Zanuttigh (2005)

Stolk et al. (2007), Wilhelmsson et al. (1998)

Airoldi et al. (2005)

Artificial reefs, harbours, Fayram \& de Risi (2007)
Burcharth et al. (2007), Herbert et al. (2011, 2013), Firth et al. (2013)

Wilding \& Sayer (2002), Wilding (2014)

Black (2001), Fletcher et al. (2011)

Southward \& Orton (1954), Sammarco et al. (2004), Firth et al. (2014)

Borsje et al. (2011), Perkol-Finkel et al. (2012), Pearce et al. (2014), Firth et al. (2015)

Table 3 Summary of organisms of conservation importance associated with artificial structures

\begin{tabular}{|c|c|c|c|c|}
\hline Taxa & Relevant legislation & Type of structure, location & References & AU: Verify that \\
\hline Algae & & & & Table 3 are OK \\
\hline $\begin{array}{l}\text { Cystoseira amentacea } \\
\text { var. stricta, } C . \\
\text { barbata, } C \text {. compressa }\end{array}$ & Bern & $\begin{array}{l}\text { Coastal defences, northern } \\
\text { Adriatic }\end{array}$ & $\begin{array}{l}\text { Susini et al. (2007), } \\
\text { Perkol-Finkel et al. (2012), } \\
\text { Firth et al. (2014), Ferrario } \\
\text { et al. (unpublished) }\end{array}$ & \\
\hline Lithophyllum byssoides & Bern & $\begin{array}{l}\text { Coastal defences, western } \\
\text { Mediterranean }\end{array}$ & García-Gómez et al. (2014) & \\
\hline
\end{tabular}




\section{OCEAN SPRAWL}

Table 3 (Continued) Summary of organisms of conservation importance associated with artificial structures

\begin{tabular}{llll}
\hline Taxa & Relevant legislation & Type of structure, location & References \\
\hline $\begin{array}{l}\text { Porifera } \\
\text { Spongia agaricina }\end{array}$ & Bern & Coastal defences, western & García-Gómez et al. (2014) \\
Tethya aurantium & Barcelona & $\begin{array}{l}\text { Mediterranean } \\
\text { Coastal defences, western } \\
\text { Mediterranean }\end{array}$ & García-Gómez et al. (2014)
\end{tabular}

\section{Anthozoa}

Astroides calycularis

CITES, Bern

Corralium rubrum

Bern

Lophelia pertusa

CITES, Habitats

\section{Polychaeta}

Sabellaria alveolata Habitats

Sabellaria spinulosa

Habitats, Bern

\section{Mollusca}

Charonia lampas,

Dendropoma

petraeum, Lurida

lurida

Cymbula nigra

Lithophaga lithophaga

Patella ferruginea

Bern, Habitats

Bern

Bern, Barcelona
Coastal defences, western

Mediterranean

Artificial reefs, Monaco

Oil platforms, North Sea

Coastal defences, western United Kingdom

Renewable energy installations, southern North Sea, United

Kingdom

CITES, Bern, Habitats

Bern

Bern, Barcelona, Habitats

Bern

Bern

Maja squinado

Bern

Palinurus elephas

IUCN (VU), Bern
Coastal defences, western

Mediterranean

Coastal defences, western

Mediterranean

Coastal defences and harbours, western Mediterranean and Adriatic

Coastal defences, western Mediterranean

Seawalls, Azores, Portugal

Sediments near coastal defences, western Mediterranean

Sediments near coastal defences, western Mediterranean

Coastal defences and marine renewable energy installations, western Mediterranean

Coastal defences, western

Mediterranean

Coastal defences, western

Mediterranean
García-Gómez et al. (2014)

Allemand et al. (2000)

Gass \& Roberts (2006)

Firth et al. (2013, 2015),

Evans et al. (2015)

Pearce et al. (2014)

García-Gómez et al. (2014)

Rivera-Ingraham et al. (2011), García-Gómez et al. (2014)

Devescovi \& Iveša (2008), García-Gómez et al. (2014)

Guerra-García et al. (2004), Espinosa et al. (2006, 2008), Rivera-Ingraham et al. (2011), GarcíaGómez et al. (2014)

Martins et al. (2010)

García-Gómez et al. (2014)

García-Gómez et al. (2014)

Langhamer \& Wilhelmsson (2009), Garcia-Gomez et al. (2014)

García-Gómez et al. (2014)

García-Gómez et al. (2014)

Continued 


\section{LOUISE B. FIRTH ET AL.}

Table 3 (Continued) Summary of organisms of conservation importance associated with artificial structures

\begin{tabular}{|c|c|c|c|}
\hline Taxa & Relevant legislation & Type of structure, location & References \\
\hline Scyllarus arctus & IUCN (LC), Bern & $\begin{array}{l}\text { Coastal defences, western } \\
\text { Mediterranean }\end{array}$ & García-Gómez et al. (2014) \\
\hline \multicolumn{4}{|l|}{ Echinodermata } \\
\hline $\begin{array}{l}\text { Centrostephanus } \\
\text { longispinus }\end{array}$ & Bern, Barcelona & $\begin{array}{l}\text { Coastal defences, western } \\
\text { Mediterranean }\end{array}$ & García-Gómez et al. (2014) \\
\hline Echinus esculentus & IUCN (LR/NT) & Coastal defences, Isle of Man & Moore (1934) \\
\hline $\begin{array}{l}\text { Paracentrotus lividus, } \\
\text { Ophidiaster } \\
\text { ophidianus }\end{array}$ & Bern & $\begin{array}{l}\text { Coastal defences, western } \\
\text { Mediterranean }\end{array}$ & García-Gómez et al. (2014) \\
\hline \multicolumn{4}{|l|}{ Osteichthyes } \\
\hline Caranx crysos & CITES, IUCN (LC), Bern & $\begin{array}{l}\text { Oil platforms, northern Gulf of } \\
\text { Mexico }\end{array}$ & Keenan (2002) \\
\hline $\begin{array}{l}\text { Hippocampus } \\
\text { brevirostris }\end{array}$ & $\begin{array}{l}\text { CITES, IUCN (data } \\
\text { deficient), OSPAR, } \\
\text { Bern, Barcelona }\end{array}$ & $\begin{array}{l}\text { Coastal defences, western } \\
\text { Mediterranean }\end{array}$ & García-Gómez et al. (2014) \\
\hline $\begin{array}{l}\text { Hippocampus } \\
\text { abdominalis, H. whitei }\end{array}$ & $\begin{array}{l}\text { CITES, IUCN (data } \\
\text { deficient) }\end{array}$ & $\begin{array}{l}\text { Swimming nets, Sydney harbour, } \\
\text { Australia }\end{array}$ & $\begin{array}{l}\text { Clynick (2008), Hellyer } \\
\text { et al. (2011) }\end{array}$ \\
\hline Epinephelus coioides & IUCN (NT) & Artificial reefs, Arabian Gulf & Feary et al. (2011) \\
\hline $\begin{array}{l}\text { Epinephelus } \\
\text { marginatus }\end{array}$ & IUCN (EN), Bern & $\begin{array}{l}\text { Coastal defences and artificial } \\
\text { reefs, western Mediterranean }\end{array}$ & $\begin{array}{l}\text { Charbonnel et al. (2002), } \\
\text { García-Gómez et al. (2014) }\end{array}$ \\
\hline $\begin{array}{l}\text { Oncorhynchus } \\
\text { tshawytscha }\end{array}$ & ESA & $\begin{array}{l}\text { Coastal defences, Puget Sound, } \\
\text { USA }\end{array}$ & Toft et al. $(2010,2013)$ \\
\hline Sciaena umbra & CITES, Bern & $\begin{array}{l}\text { Coastal defences and artificial } \\
\text { reefs, western Mediterranean }\end{array}$ & $\begin{array}{l}\text { Charbonnel et al. (2002), } \\
\text { García-Gómez et al. (2014) }\end{array}$ \\
\hline \multicolumn{4}{|l|}{ Chondrichthyes } \\
\hline Pristis pectinata & IUCN (CR), CITES, ESA & Seawall-lined canals, Florida & Poulakis et al. (2013) \\
\hline Rhincodon typus & $\begin{array}{l}\text { CITES, IUCN (VU), } \\
\text { UNCLOS, CMS }\end{array}$ & Oil platforms, Arabian Gulf & Robinson et al. (2013) \\
\hline
\end{tabular}

Note: Species were selected if protected under international or national legislation. Barcelona, Convention for the Protection of the Mediterranean Sea Against Pollution; Bern, Bern Convention on the Conservation of European Wildlife and Natural Habitats; CITES, Convention on International Trade in Endangered Species of Wild Fauna and Flora; CMS, Convention on the Conservation of Migratory Species of Wild Animals; ESA, Endangered Species Act, USA; Habitats, EU Habitats Directive on the Conservation of Natural Habitats and of Wild Fauna and Flora; IUCN, International Union for Conservation of Nature Red List (categories: LC, Least Concern; LR, Lower Risk; NT, Near Threatened; VU, Vulnerable; EN, Endangered; CR, Critically Endangered); UNCLOS, United Nations Convention on the Law of the Sea.

of pioneering research on methods of removal of non-indigenous species and the transplantation of desirable species on to artificial structures. All of the examples that follow are from relatively recent studies, and it must be noted that this form of marine wildlife management is very much in its infancy. Much more research is required before removals or transplants can be advocated as generic management strategies for artificial structures.

\section{Removal of non-indigenous species}

Regarding removal of non-indigenous species, there are several examples where traditional methods (e.g., physical and chemical control) have been used in unsuccessful attempts to control or eradicate marine pests such as the colonial ascidian Didemnum vexillum (Coutts \& Forrest 2007, 
Forrest \& Hopkins 2013, McCann et al. 2013); the solitary ascidian Ciona intestinalis (Carver et al. 2003, Aldred \& Clare 2014); and the brown macroalgae Sargassum muticum (Farnham \& GarethJones 1974, Critchley et al. 1986) and Undaria pinnatifida (Hewitt et al. 2005). There are many challenges and limitations with traditional control methods for target marine pests, especially those that rely on chemical treatment or repeated diver detection, maintenance, and removal of visible organisms (Caffrey et al. 2010, 2011, Atalah et al. 2013a). Atalah et al. (2014) advocated that many of the limitations could be overcome with biocontrol (i.e., control by natural predators, either native or non-indigenous) as effective control agents will have a sustained effect on all life stages of target species or multispecies assemblages. This method of control of non-indigenous species is relatively well established in terrestrial and freshwater aquatic systems (e.g., Newman et al. 1996, Baars et al. 2010, Mangan \& Baars 2013). Despite the promising preliminary results to date, this field is very much in its infancy in the marine environment (but see Atalah et al. 2013a,b, 2014, 2015), and further research is needed in this area.

\section{Transplanting of desirable species}

The growth of ecologically valuable benthic communities can be promoted through direct transplanting of desirable target species. The transplanting of corals on to artificial reefs has long been common practice in coral-reef rehabilitation and fisheries enhancement on artificial reefs (e.g., Clark \& Edwards 1994, Perkol-Finkel \& Benayahu 2009). In a recent study Ng et al. (2015) investigated the feasibility of transplanting corals and sponges to the intertidal zone of seawalls. After only 18 months, species with massive and encrusting growth forms were most successful at establishing on the seawall and were even observed to provide food and shelter for reef fish and gastropods. Despite the short-term nature of this study, the results indicated that the transplantation of nurseryreared reef biota is a viable strategy that enhances the ecological value of seawalls. Habitat-forming algae (e.g., Cystoseira barbata) can be successfully transplanted on to artificial structures (Falace et al. 2006, Susini et al. 2007, Perkol-Finkel \& Airoldi 2010, Perkol-Finkel et al. 2012), but care should be taken to protect younger individuals from biotic disturbance from grazers (Ferrario et al. unpublished data).

Mussels are important filter-feeders and provide an important biofiltration service by removing toxins and particulates and preventing unsightly and potentially toxic phytoplankton blooms, contributing to improved water quality in both natural and artificial settings (e.g., Wilkinson et al. 1996). One example from the United Kingdom describes how mussels settled on to ropes in an experimental fish farm (Russell et al. 1983, Hawkins et al. 1992a,b) and were transplanted into experimental docks in Liverpool, leading to recovery of these enclosed artificial ecosystems (Allen et al. 1992, Allen \& Hawkins 1993, Allen et al. 1995, Wilkinson et al. 1996).

\section{Eco-engineering: creating novel habitats for biodiversity enhancement}

The field of eco-engineering (the integration of ecological, economic, and societal needs in the design of artificial habitats) has received much attention in recent years (for reviews, see Dugan et al. 2011, Dafforn et al. 2015a,b, Dyson \& Yocom 2015). A major output of this surge of research has been a wide range of studies that have implemented small-scale modifications on artificial structures that can be widely applied in a range of different situations. Due to access and cost implications, the vast majority of this work has focused on intertidal seawalls and coastal defence structures. A number of recent reviews provided excellent summaries of the different management approaches to coastal development (see Dyson \& Yocom (2015) for a comprehensive review of ecological design for urban waterfronts and Dafforn et al. (2015a) for a broader approach to restoration and hard and soft engineering).

Here we specifically cover the various ecological engineering techniques that have been tested on hard artificial structures (Figures 10 and 11; Table 1). On artificial structures in the marine 
environment eco-engineering is largely implemented to increase heterogeneity and complexity of otherwise topographically simple and featureless substrata. Ideally, engineering modifications should be implemented during construction (see the discussion that follows). A range of options is also available for retrofitting enhancements on to existing structures. Microhabitats such as pits, crevices, and rock pools are important refuges from abiotic and biotic stress and disturbance on natural rocky shores, thus supporting diverse communities (Moschella et al. 2005, O'Connor \& Crowe 2005, Firth et al. 2009, Firth \& Crowe 2010). These microhabitats are largely absent from artificial structures (Moschella et al. 2005, Firth et al. 2013b).

\section{Texturing and the addition of pits and ledges (millimetre-centimetre scale)}

The incorporation of surface roughness, pits, grooves, and ledges can facilitate the persistence of species that would not normally be able to live on a featureless surface (Firth et al. 2014b). They can also promote species of conservation and commercial importance (Martins et al. 2010). Surface roughness and pits and crevices can be incorporated directly on to artificial structures by drilling directly into the substratum (Figure 10A; Martins et al. 2010, Firth et al. 2014b); by manipulating the concrete between the blocks on seawalls (Figure 11A; Chapman \& Underwood 2011, Firth et al. 2014b); or by affixing precast or predrilled habitat enhancement tiles or plates (Figure 11B-11D; Moschella et al. 2005, Chapman et al. 2008, Borsje et al. 2011, Witt et al. 2012, Toft et al. 2013, Loke et al. 2014, Coombes et al. 2015). Recently, 3-dimensional printing has been used to create artificial enhancement units (Talia Sherrard personal communication).

Water-retaining features (centimetre-metre scale)

Water-retaining features (i.e., rock pools) are particularly important in artificial habitats (Moschella et al. 2005, Firth et al. 2013a). A wide range of techniques has been tested on seawalls and coastal defences, all of which had similar results, increasing taxon richness and functional diversity (Table 1; Figures 10 and 11). Deep and shallow pools drilled directly into the boulders of rock armour at Tywyn in Wales showed no significant differences in colonizing diversity but did show differences in community structure (Figure 10B; Firth et al. 2014b, Evans et al. 2015). Even after 18 months, the cumulative number of taxa colonizing the pools had not levelled off (Evans et al. 2015), indicating that a greater diversity of transient and ephemeral taxa were utilizing the novel habitats at different times of year. This intervention requires horizontal or near-horizontal substrata but can be implemented in locations of all exposures, ranging from sheltered to very exposed. The drilled pools remained undamaged following the extreme storms of 2013-2014 (Evans personal AU: Provide first observations), indicating that drilling pools may represent a long-term option that will be resilient to storm and wave damage.

Pools were incorporated into Sydney, Australia, seawalls during repair works by replacing sandstone blocks with a lip that retained water, thus functioning as a shaded rock pool supporting significantly greater diversity and abundance of epibiota than the existing seawall (Chapman \& Blockley 2009). This option can only be implemented during construction work and in relatively sheltered environments due to danger of damage to the seawall from wave action. Depending on the size of the blocks used for constructing the seawall, the size of cavities can be varied to offer a range of different habitat types along the same stretch of seawall.

Manipulating concrete can also create rock pools. Taking advantage of cores drilled through boulders on a groyne in North Wales (Figure 10C), Firth et al. (2014) in-filled these cores with AU: Indicate

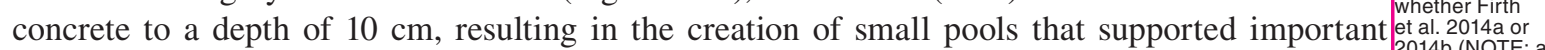
habitat-forming crustose coralline algae after only 6 months. A potentially universal method of and b designacreating rock pools on rock armour is by pouring concrete among the boulders or concrete units. trom your Buckets were placed in wet concrete that was poured at the base of concrete units in Galway Bay, Ireland (Figure 10D). Once the concrete had set, the buckets were removed, yielding water-retaining 
features that supported a wide variety of organisms that were not otherwise present on the structure AU: Provide first (Firth unpublished data). These manipulations were unaffected by the severe storms of 2013-2014, which caused severe damage in Galway Bay, indicating that this option may also be a long-term solution that will be resilient to storm and wave damage.

\section{Precast concrete units (beyond metre scale)}

A wide variety of materials has been used in artificial reef construction, including used tyres, old vehicles, boats, pipes, fibreglass, metal, building materials, and waste products from industry (Collins et al. 1994, Chou 1997, Jensen et al. 2000, Collins et al. 2002, Loh et al. 2006). The Reef Ball is perhaps one of the most famous and successful examples of a purpose-built precast habitat enhancement unit (Harris 2009) that can be used for a variety of purposes, ranging from coral and oyster reef rehabilitation to mangrove planting. This concept has been applied to artificial structures deployed in the intertidal zone with the development of a range of different precast concrete habitat enhancement units. The BIOBLOCK is a large unit that has multiple habitats in a single unit (pits, ledges, rock pools; Figure 10E) that can replace rock armouring boulders and can be retrofitted or deployed during construction (Firth et al. 2014b). The BIOBLOCK is another potentially universal method of habitat creation in rock armouring that can be implemented in a range of different exposures, ranging from sheltered to very exposed. At $5.4 \mathrm{t}$, it is unlikely to be moved during a storm and represents a potential long-term option that will be resilient to storm and wave action.

A clever way of incorporating water-retaining features on existing seawalls is the attachment of modified concrete flowerpots (Figure 11E; Browne \& Chapman 2011, 2014), a concept that captured a lot of media attention in Sydney and has now been applied elsewhere (e.g., Vertipools on the Isle of Wight, UK; Figure 11F). Dyson \& Yocom (2015) described seawall stairs as precast concrete steps designed to increase nearshore habitat area. These add both horizontal surfaces and microhabitat to the urban waterfront by incorporating exposed aggregate (surface texture) and depressions designed to mimic tide pools and may provide habitat, enhance food production, and improve migration corridors for juvenile salmon and other organisms (Enabling the Business of Agriculture [EBA] 2011).

Interdisciplinary research among ecologists, engineers, and materials scientists is rapidly advancing the field with the design of environmentally friendly concrete (e.g., Econcrete ${ }^{\circledR}$ ) and other materials for the production of artificial reef units (Loh et al. 2006, Ponti et al. 2015); armouring units (Perkol-Finkel unpublished data); pile encapsulation (Perkol-Finkel \& Sella 2014, 2015); rock pools (Figure 10F; Perkol-Finkel \& Sella 2015); and seawalls (Figure 11B; Toft et al. 2013). All of this can be retrofitted to existing structures or indeed considered at the planning stage and incorporated during construction.

\section{Other novel approaches to habitat enhancement}

Rock-filled gabion baskets and mattresses are also widely used in more sheltered locations. Preliminary work carried out by Firth et al. (2014b) revealed that by careful selection of the stone sizes it is possible to enhance diversity and abundance of epibiota, and these habitats undoubtedly provide refuge from predation as well as wave action and adverse thermal conditions for mobile fish and crustaceans. Further research is required to fully test the potential for this feature to be incorporated into design of new structures as a management option.

Habitat benches can be constructed on top of and adjacent to seawalls to create areas of shallow water. The addition of novel shallow-water habitat may provide habitat for benthic flora and fauna and mobile fish and crustaceans (Toft et al. 2010, 2013, Chapman \& Underwood 2011). Finally, baskets can be attached to seawalls to support both submergent and emergent vegetation, which in turn may provide habitat and nursery grounds for other shallow-water species (Holloway \& Connell 2002, Perkol-Finkel et al. 2008; see Dyson \& Yocom 2015). 
Designation of sites as reefs or de facto reserves

All artificial structures have the capacity to act as both artificial reefs and fish aggregation devices through the 'artificial reef effect' (e.g., Rilov \& Benayahu 1998, Love et al. 1999, Helvey 2002, Reubens et al. 2011, 2013). Owing to the potential for collision between vessels and marine renewable energy installations or fishing gear entanglement, it is not possible to undertake many forms of commercial fishing within the immediate vicinity of marine renewable energy installations. Providing a refuge from intense fishing pressure, artificial structures have the potential to protect and enhance exploited stocks (Wilhelmsson et al. 2006, Wilhelmsson \& Malm 2008, Langhamer et al. 2009). In recent years various authors have discussed the potential for marine renewable energy installations to act as de facto marine protected areas (MPAs) (Inger et al. 2009, Witt et al. 2012, Ashley et al. 2014). Ultimately, the implementation of such MPAs will also enrich benthic biota by locally eliminating the damage caused by fishing gear towed along the seabed (e.g., Pearce et al. 2014).

\section{Artificial marine microreserves}

Occasionally, endangered and threatened species can be found in high densities on artificial structures (Guerra-García et al. 2014). In the Mediterranean, overexploited molluscs have been found on coastal defence structures in harbours. The limpet Patella ferruginea is the most endangered invertebrate in the Mediterranean but can be found in abundance in the Port of Ceuta, Tunisia (Guerra-García et al. 2004, Espinosa et al. 2006a,b, 2008, Rivera-Ingraham et al. 2011). Similarly, the overexploited date mussel Lithophaga lithophaga is found in abundance on the soft limestone breakwaters in Rovinj, Croatia (Devescovi \& Iveša 2008). In a similar way to marine renewable energy installations functioning as de facto reserves from the impacts of fishing pressure, artificial coastal constructions like breakwaters, docks, and harbours may be closed to the public and ultimately prevent harvesting and fishing (García-Gómezet al. 2011). Following the discovery of abundant populations of Patella ferruginea in the Port of Ceuta, there have been proposals for the establishment of artificial sites termed artificial marine microreserves (AMMRs), where some endangered species experience a refuge from human disturbance (García-Gómez et al. 2011, 2014).

\section{Other protection status for artificial structures}

Artificial structures can be considered important for other reasons, such as heritage or scientific value. Harbours, ports, and piers are often designated for their historic value, and many even have UNESCO World Heritage status. For example, the disused docks of Liverpool, England, fall within the Liverpool Maritime Mercantile City UNESCO site and represent an important example of an urban 'lagoonoid' system supporting high biodiversity in clean waters (Allen et al. 1995, Hawkins et al. 2002). Furthermore, the conservation value of the Elmer network of artificial coastal defence structures on the southern coast of England has been recognized by the proposed designation as a Site of Special Scientific Interest (SSSI). This is largely because of the vegetated shingle but also because of the animals and plants colonizing the breakwaters (Burcharth et al. 2007).

\section{Should it stay or should it go? Applications of the Rigs-to-Reefs concept}

The removal of existing structures has significant environmental and financial costs (Dafforn et al. 2015b). The typical lifespan of oil platforms and wind farms is 17.5 and 20-30 years, respectively (Pulsipher et al. 2001, Ortegon et al. 2012). Macreadie et al. (2011) estimated that 6500 oil and gas platforms are due for decommissioning by 2025, with an estimated cost of $\$ 8$ billion for the Gulf of

Mexico alone (Kolian and Sammarco 2005). The Rigs-to-Reefs programme was developed in the United States to convert decommissioned offshore oil and gas platforms into artificial reefs (Kaiser \& Pulsipher 2005). This initiative operates under a 'win-win' premise (Rosenzweig 2003), whereby obsolete rigs are recycled as artificial reefs with the primary goal to provide substantial cost savings 
for the oil and gas industry while providing secondary benefits through benthic habitat conservation and fisheries management. Macreadie et al. (2011) discussed how this perception is widely recognized despite little evidence supporting the 'production hypothesis' over the 'attraction hypothesis' (Pickering \& Whitmarsh 1997). Since the implementation of the programme in the United States, similar schemes have been implemented throughout South-East Asia and Mexico. There was interest in implementing the programme in Europe, but following much debate, environmental opposition has prevented the implementation of Rigs-to-Reefs in the North Sea (Picken \& McIntyre 1989, Picken et al. 2000, Baine 2002, Sayer \& Baine 2002).

The Rigs-to-Reefs concept has been proposed recently as a potential management strategy, termed renewables-to-reefs, for the large number of European wind farms that will be decommissioned in the future (Smyth et al. 2015). This new technology means few baseline data are currently available (Ashley et al. 2014). Much of the focus of the construction of marine offshore renewable energy installations has focused on the impact on marine megafauna, birds, and the receiving environment (Carstensen et al. 2006, Drewitt \& Langston 2008, Bailey et al. 2010), with little consideration of the fouling communities.

Sammarco et al. (2014) provided one of the few studies that has conducted a quantitative assessment of different options for Rigs-to-Reefs. They found no significant difference in coral density between standing and toppled oil platforms and recorded that the invasive coral Tubastraea coccinea was more abundant on the toppled compared to standing rigs. While Rigs-to-Reefs may potentially represent a popular and viable option by reducing access to towed fishing gear, with little existing data, careful consideration will be required in relation to the management goals, and each installation should be considered on a case-by-case basis (Smyth et al. 2015).

\section{Planning future developments}

Some of the greatest advances can potentially be made as a result of broader consideration, at the design stage, of the ecological consequences of new structures. In particular there is a need to recognize that the overarching drivers for construction in the marine environment (sea-level rise, global trade infrastructure, tourism) often operate at a much broader scale than the 'impacts' on society (flooding in a particular part of a town) and the associated societal responses (construction of a seawall to protect that location) (Smyth et al. 2015). Equally important in the context of this review, the ecological consequences of coastal structures can have far-reaching effects on species and habitats away from the structures themselves. Hence there is a clear need for marine spatial planning to consider synergistic and antagonistic consequences at broad spatial and temporal resolution (Kidd 2007; Fischer et al. 2009, Jay et al. 2012). Such consideration needs to be incorporated at the design and planning stage to maximize opportunities and minimize threats. For example, in large arrays of structures there could be potential to enhance stocks of commercially important species by green engineering. Similarly, it may be possible to achieve synergistic benefits by designing multifunctional structures for a range of different purposes. Overall it is important to work with nature using an ecosystem-based approach.

\section{Ecological engineering}

At present the evidence base for ecological benefits from engineering modifications comes from relatively small-scale interventions. Few studies describe eco-engineering that has been incorporated into the planning stage of a new development. In the previous section, we reviewed the range of Au: It would be

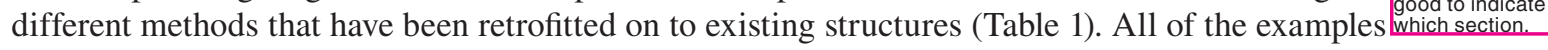
could be considered at the design phase. Whenever and wherever possible, eco-engineering should be incorporated into a project during construction rather than retrospectively. Any manipulations will be cheaper, can be implemented on a much larger scale, can take advantage of heavy-lifting machinery on site, and can be covered by the existing licence for the construction work. They can also be considered in any environmental assessment at the design stage. 
Langhamer \& Wilhelmsson (2009) conducted one of the few eco-engineering studies implemented at the design phase. They showed that small holes cast into the concrete base of wave energy converters had a significant positive effect on the abundance of the commercially important crab Cancer pagurus. Furthermore, the European lobster (Homarus gammarus) was also found to occupy these holes (Table 1). Hence, there could be real opportunities here, for example, to create local potting fisheries in areas where arrays of wind turbines now preclude fishing by trawling. Further research is essential to determine the long-term effects and in particular whether these manipulations represent new 'production' as opposed to 'attraction' of mobile organisms from elsewhere (Pickering \& Whitmarsh 1997, Baine 2001, Spanier et al. 2011). Whichever applies, concentrating shellfish in defined areas makes pot and creel fisheries more productive.

\section{Multifunctional structures}

In light of the potential negative impacts of introducing additional novel habitats to the marine environment, multifunctional structures may provide a better option for fisheries enhancement and spatial efficiency. For example, secondary fisheries benefits may be designed-in to multifunctional coastal structures (e.g., Wilhelmsson et al. 2010, Zanuttigh et al. 2015) alongside their primary function as coastal defence that has been deemed essential or appropriate for shoreline management (e.g., Scyphers et al. 2015). Albertelli et al. (1995) suggested that using artificial structures for aquaculture of Lithophaga lithophaga might help to divert pressure from the very damaging harvesting techniques on natural reefs (Fanelli et al. 1994). However, care is needed to ensure destructive harvesting methods are still compatible with the primary function of structures. Alternatively, collocation of aquaculture with offshore industries may be viable, thereby increasing food or biofuel provision while minimizing additive impacts that would result from multiple and more dispersed developments resulting from single-use constructions (e.g., Buck et al. 2008, Zanuttigh et al. 2015). However, multifunctional usage needs to be considered from multiple perspectives (engineering, ecological, societal) to ensure synergies rather than conflicts of interest (Scyphers et al. 2015).

Water filtration by diverse rocky-reef assemblages has been linked to societal benefits of a coastal breakwater in an integrated approach to beach management in Italy (Lamberti \& Zanuttigh 2005). Consequently, there is growing interest in artificial reefs (including coastal protection reefs) that are constructed from, seeded by, or are naturally colonized by oysters and other filter-feeding organisms (Piazza et al. 2005, Gao et al. 2008, Borsje et al. 2011, Reckenbeil \& Ozbay 2014, Scyphers et al. 2015). It is important to consider the outcomes holistically. Wilhelmsson \& Malm (2008) pointed out the risk associated with a lack of understanding of the potential for dense aggregations of filtrating animals (on wind farm pilings) to profoundly affect ecosystem dynamics (e.g., see Maar et al. 2010).

Artificial reefs used for coastal protection can also enhance recreational amenities, such as surfing, and are known as multifunctional artificial reefs (MFARs). For example, artificial surf reefs (ASRs) have been successfully developed in Australia, New Zealand, the United Kingdom, and the United States (Fletcher et al. 2011, Mead et al. 2011), with others planned for the Azores (Ng et al. 2015). Not all such constructions have functioned well for surfing activities. Constructed in 2008, Boscombe Surf Reef is a multifunctional artificial reef on the southern coast of England that has been criticized for failing as an ASR, yet its value as habitat for a wide range of organisms has been widely recognized, with it now being a popular snorkelling site as part of a larger 'coastal activity park' (Fletcher et al. 2011, Herbert et al. 2013).

\section{Hybrid engineering and the ecosystem approach: building with nature}

In addition to the potential environmental impacts and poor habitat quality of artificial structures described previously, 'hard' coastal defence approaches are often extremely expensive. In the absence of adequate coastal zone management and marine and maritime spatial planning, they can lead to inappropriate coastal development along eroding or low-lying coasts. They can also 
exacerbate coastal erosion through 'coastal squeeze' of natural intertidal habitats (Turner et al. 2007, Govaerts \& Lauwaert 2009). Consequently, 'soft' engineering approaches, such as beach replenishment, sand dune stabilization, and managed realignment, are widely considered to be more sustainable options for flood and coastal erosion risk management (Turner et al. 2007, Govaerts \& Lauwaert 2009). Nevertheless, in scenarios where no alternative options are viable for protecting people and assets, many shoreline management plans continue to recommend a strategy of 'hold the line'. This means that local authorities are required to maintain existing defences and potentially augment these with additional hard protection measures. Where hard defence structures are considered necessary for flood and coastal erosion risk management, it is essential that they be implemented with ecologically sensitive design to minimize impacts on the natural environment (Firth et al. 2014b, Hoggart et al. 2014).

Some locations are already implementing the ecosystem and hybrid approaches to coastal defence (e.g., Bilkovic \& Mitchell 2013, Temmerman et al. 2013). For example, in Selangor, Malaysia, breakwaters and geotextile tubing were deployed in front of degraded mangroves at two locations, reducing wave energy and protecting seedlings of transplanted mangroves (Hashim et al. 2010, Kamali et al. 2010, Kamali \& Hashim 2011, Tamin et al. 2011). Such rehabilitation practices are not currently widely used in conjunction with coastal protection (but see Perkol-Finkel et al. 2012, Firth et al. 2014b). These preliminary studies showed the potential for cost-effective habitat rehabilitation. Any rehabilitation technique, however, must take into consideration ecological principles, including detailed knowledge of the species concerned (Dafforn et al. 2015b). It is also important to have clear restoration targets against which to measure success (Hawkins et al. 2002, Knights et al. 2014) and where possible to work by 'nudging nature' (Hawkins et al. 1999) to achieve maximum leverage from natural capital. We can build on these early successes and develop a more robust and widespread use of hybrid structures viewed using an ecosystem approach. To echo the plea by Sutton-Grier et al. (2015), now is the time to design, test, research, develop, and apply hybrid structures and the ecosystem approach to protect human populations and infrastructure and strengthen coastal resilience (Spalding et al. 2014).

\section{Managing artificial structures and infrastructure and the need for marine spatial planning}

Structures placed in the sea can have impacts ranging from the local-scale (1- to 10-m) loss or modification of habitat to much larger scales (over hundreds of kilometres) by influencing networks of connectivity. Widespread habitat modification, particularly of fringing coast, modification of sediment transport across large areas of seabed by structure placement, or crossing of the seabed by power cables and pipelines can lead to modification at the 1000-km scale (Dafforn et al. 2015a, Goodsir et al. 2015). The extent and type of impact will be determined partly by the attributes of the structures themselves, for example, in the manner and extent to which they modify not only sediment transport (Wilhelmsson et al. 2010) but also their its arrangement (Dafforn et al. 2015a, Huang et al. 2015), hence the need for marine (or maritime) spatial planning.

Many structures are built in response to local needs, often by locally focused businesses (such as holiday resorts or hotels) or authorities (ports, local municipal councils). These can then scale up over extensive stretches of coastline. Perhaps the best-documented example is in the northern Adriatic, where over $80 \%$ of the coastline is now defended, often with one defence starving an adjacent location of sediment and exacerbating erosion (Airoldi et al. 2005a, Burcharth et al. 2007). Isolated patches ('islands') of artificial, mainly hard and modified, habitats surrounded by natural, usually soft sediment, habitat can also occur. The scope for colonization of such islands (e.g., an isolated offshore rig or a single breakwater or jetty on a sandy coast) will be restricted by suitability of the receiving habitat and hydrodynamics influencing larval supply, settlement, and recruitment to adult populations as well as food supply (Floerl \& Inglis 2005). For example, Airoldi et al. (2015) found non-indigenous species were two or three times more abundant on infrastructure built along 
sedimentary coastlines than on natural rocky reefs or infrastructure built close to rocky coastlines in the northern Adriatic. Dafforn et al. (2015b) suggested that the designs and placements of different structures could restrict (breakwaters enclosing marinas) or enhance (dense configuration of pilings, pontoons, breakwaters) larval exchange and hence connectivity (Thomas 2011). On the Adriatic coast of Italy connectivity has been increased, facilitating the spread of non-indigenous species (Airoldi \& Bulleri 2011, Airoldi et al. 2015). These examples emphasize the importance of spatial planning for urban development; this is as important in the sea as on land (Dafforn et al. 2015b).

\section{Limitations}

Research focusing on the ecological consequences of coastal construction is now fairly extensive, and there are data indicating the potential for modification of engineering design to influence ecological outcomes. Our ability to achieve specific ecological objectives, such as boosting stocks of commercially important species or minimizing the spread of non-indigenous species, is still limited. One of the key drivers behind coastal construction is societal need, yet we know little about human perceptions of these constructions, in particular perceptions relating to different designs and differing ecological outcomes (but see van Loon-Steensma \& Slim 2013). For example, the availability of alternative designs with known and predictable different outcomes may be valuable in gaining public engagement during the consenting process. In addition to debate about whether a structure should be built (i.e., managed retreat or soft defences), there should be discussion about what type of structure should be built (Wilson et al. 2015), including secondary outcomes. There is a growing body of work on perception of the natural world (e.g., Wyles et al. 2014, 2015) and in particular use of visualizations to help understand perceptions about future scenarios relating, for example, to flooding and climate change (e.g., Sheppard 2012, Tebboth 2014). Such approaches need to be incorporated within the planning and consenting process for coastal structures.

There is also limited understanding of the interactive effects between structures, and the underlying drivers for their construction, and other environmental challenges, such as proliferation of pest species (e.g., jellyfish) and non-indigenous species, and interactive effects with climate change. Despite this gap in our knowledge, it is important to consider construction within the context of the multiple stressors that now challenge our environment.

\section{Future directions}

Looking to the future, it is essential to consider all of the relevant concerns and benefits in a wider perspective of marine spatial planning. The deployment of artificial structures in the marine environment has the potential to cause conflict among interest groups, including the public, energy companies, the fishing sector, and environmental groups. Conflicts should be minimized by integrating key stakeholders from the outset into the design, siting, construction, and operational phases of the installations and by providing clear evidence of both positive and negative potential environmental consequences (Scyphers et al. 2015, Wilson et al. 2015). It is also important to consider this in a framework of global change so that planning considers temporal as well as spatial elements.

\section{Concluding remarks}

Often, we have considered structures either in isolation or as part of a network of similar structures, for example, windfarms (Adams et al. 2014), oil and gas platforms (Sammarco et al. 2010, 2012), coastal defences (Airoldi et al. 2015), or ports and harbours (Peters et al. 2014, Rius et al. 2014). With the increasing human population, continued ocean sprawl, the increase in global shipping, and biotic homogenization, these structures could begin to function as super 'artificial networks'. For example, there are already some 4000 structures in the Gulf of Mexico, referred to as the 'steel archipelago' (Villareal et al. 2007). The challenge is therefore to take a holistic view of this 
bigger picture in terms of spatial scale and at the same time to consider the challenges in terms of multiple stressors (e.g., pollution, see Dafforn et al. 2009, Crooks et al. 2011; climate change, see Occhipinti-Ambrogi 2007; pest species [e.g., jellyfish], see Lo et al. 2008, Ishii \& Katsukoshi 2010, Duarte et al. 2012; toxic algae, see Vila et al. 2001, Villareal et al. 2007; extreme climatic events, see Firth et al. 2011, Diez et al. 2012, 2015a, Wernberg et al. 2013, Smale \& Vance 2015), both now and in the future. The potential rewards from such a holistic approach are considerable, with real opportunities for 'win-win ecology' (Rosenzweig 2003).

\section{References}

Able, K., Manderson, J. \& Studholme, A. 1998. The distribution of shallow water juvenile fishes in an urban estuary: the effects of manmade structures in the lower Hudson River. Estuaries 21, 731-744.

Adams, T.P., Miller, R.G., Aleynik, D. \& Burrows, M.T. 2014. Offshore marine renewable energy devices as stepping stones across biogeographical boundaries. Journal of Applied Ecology 51, 330-338.

Aguilera, M.A., Broitman, B.R. \& Thiel, M. 2014. Spatial variability in community composition on a granite breakwater versus natural rocky shores: lack of microhabitats suppresses intertidal biodiversity. Marine Pollution Bulletin 87, 257-268.

Ainouche, M.L., Baumel, A., Salmon, A. \& Yannic, G. 2004. Hybridization, polyploidy and speciation in Spartina (Poaceae). New Phytologist 161, 165-172.

Airoldi, L., Abbiati, M., Beck, M.W., Hawkins, S.J., Jonsson, P.R., Martin, D., Moschella, P.S., Sundelöf, A., Thompson, R.C. \& Åberg, P. 2005a. An ecological perspective on the deployment and design of lowcrested and other hard coastal defence structures. Coastal Engineering 52, 1073-1087.

Airoldi, L., Bacchiocchi, F., Cagliola, C., Bulleri, F. \& Abbiati, M. 2005b. Impact of recreational harvesting on assemblages in artificial rocky habitats. Marine Ecology Progress Series 299, 55-66.

Airoldi, L. \& Beck, M.W. 2007. Loss, status and trends for coastal marine habitats of Europe. Oceanography and Marine Biology: An Annual Review 45, 345-405.

Airoldi, L. \& Bulleri, F. 2011. Anthropogenic disturbance can determine the magnitude of opportunistic species responses on marine urban infrastructures. PLOS ONE 6, e22985.

Airoldi, L., Turon, X., Perkol-Finkel, S. \& Rius, M. 2015. Corridors for aliens but not for natives: effects of marine urban sprawl at a regional scale. Diversity and Distributions 21, 755-768.

Albertelli, G., Bavestrello, G., Cattaneovietti, R., Olivari, E. \& Petrillo, M. 1995. Artificial habitats for rearing slow-growing marine invertebrates. In Coastal Ocean Space Utilization III, N. Della Croce et al. (eds). London: Chapman and Hall, 455-463.

Aldred, N. \& Clare, A.S. 2014. Mini-review: impact and dynamics of surface fouling by solitary and compound ascidians. Biofouling 30, 259-270.

Allemand, D., Debernardi, E. \& Seaman, W., Jr. 2000. Artificial reefs in the Principality of Monaco: protection and enhancement of coastal zones. In Artificial Reefs in European Seas, A. Jensen et al. (eds). Dordrecht, the Netherlands: Springer, 151-166.

Allen, J.R. \& Hawkins, S.J. 1993. Can biological filtration improve water quality? In Urban Waterside Regeneration: Problems and Prospects, K.N. White et al. (eds). Chichester, UK: Ellis Horwood Press, 377-385.

Allen, J.R., Hawkins, S.J., Russell, G.R. \& White, K.N. 1992. Eutrophication and urban renewal: problems and perspectives for the management of disused docks. Science of the Total Environment Supplement, 1283-1295.

Allen, J.R., Wilkinson, S.B. \& Hawkins, S.J. 1995. Redeveloped docks as artificial lagoons: the development of brackish-water communities and potential for conservation of lagoonal species. Aquatic Conservation: Marine and Freshwater Ecosystems 5, 299-309.

Alongi, D.M. 2008. Mangrove forests: resilience, protection from tsunamis, and responses to global climate change. Estuarine, Coastal and Shelf Science 76, 1-13.

Altieri, A.H., van Wesenbeeck, B.K., Bertness, M.D. \& Silliman, B.R. 2010. Facilitation cascade drives positive relationship between native biodiversity and invasion success. Ecology, 91, 1269-1275.

An, S.Q., Gu, B.H., Zhou, C.F., Wang, Z.S., Deng, Z.F., Zhi, Y.B., Li, H.L., Chen, L., Yu, D.H. \& Liu, Y.H. 2007. Spartina invasion in China: implications for invasive species management and future research. Weed Research 47, 183-191. 


\section{LOUISE B. FIRTH ET AL.}

Andersson, M., Berggren, M., Wilhelmsson, D. \& Öhman, M. 2009. Epibenthic colonization of concrete and steel pilings in a cold-temperate embayment: a field experiment. Helgoland Marine Research $\mathbf{6 3}$, 249-260.

Aprahamian, M.W., Aprahamian, C.D. \& Knights, A.M. 2010. Climate change and the green energy paradox: the consequences for twaite shad Alosa fallax from the River Severn, UK. Journal of Fish Biology 77, 1912-1930.

Araújo, M.B., Cabeza, M., Thuiller, W., Hannah, L. \& Williams, P.H. 2004. Would climate change drive species out of reserves? An assessment of existing reserve-selection methods. Global Change Biology 10, 1618-1626.

Araújo, R., Serrão, E.A., Sousa-Pinto, I. \& Åberg, P. 2011. Phenotypic differentiation at southern limit borders: the case study of two fucoid macroalgal species with different life-history traits. Journal of Phycology 47, 451-462.

Ardre, F. 1970. Contribution á l'étude des algues marines du Portugal I. La Flore. Portugaliae Acta Biologica 10, $1-423$.

Ardre, F. 1971. Contribution á l'étude des algues marines du Portugal II. Ecologie et Chorologie. Bulletin du Centre d'Etudes et de Recherches Scientifiques, Biarritz 8, 359-574.

Arenas, F., Sánchez, I., Hawkins, S.J. \& Jenkins, S.R. 2006. The invasibility of marine algal assemblages: role of functional diversity and identity. Ecology 87, 2851-2861.

Arkema, K.K., Guannel, G., Verutes, G., Wood, S.A., Guerry, A., Ruckelshaus, M., Kareiva, P., Lacayo, M. \& Silver, J.M. 2013. Coastal habitats shield people and property from sea-level rise and storms. Nature Climate Change 3, 913-918.

Ashley, M.C., Mangi, S.C. \& Rodwell, L.D. 2014. The potential of offshore windfarms to act as marine protected areas-a systematic review of current evidence. Marine Policy 45, 301-309.

Atalah, J., Bennett, H., Hopkins, G.A. \& Forrest, B.M. 2013a. Evaluation of the sea anemone Anthothoe albocincta as an augmentative biocontrol agent for biofouling on artificial structures. Biofouling 29, 559-571.

Atalah, J., Hopkins, G.A., Fletcher, L.M., Castinel, A. \& Forrest, B.M. 2015. Concepts for biocontrol in marine environments: is there a way forward? Management of Biological Invasions 6, 1-12.

Atalah, J., Hopkins, G.A. \& Forrest, B.M. 2013b. Augmentative biocontrol in natural marine habitats: persistence, spread and non-target effects of the Sea Urchin Evechinus chloroticus. PLoS ONE 8, e80365.

Atalah, J., Newcombe, E.M., Hopkins, G.A. \& Forrest, B.M. 2014. Potential biocontrol agents for biofouling on artificial structures. Biofouling 30, 999-1010.

Atchison, A.D., Sammarco, P.W. \& Brazeau, D.A. 2008. Genetic connectivity in corals on the Flower Garden Banks and surrounding oil/gas platforms, Gulf of Mexico. Journal of Experimental Marine Biology and Ecology 365, 1-12.

Ayata, S.D., Ellien, C., Dumas, F., Dubois, S. \& Thiebaut, E. 2009. Modelling larval dispersal and settlement of the reef-building polychaete Sabellaria alveolata: role of hydroclimatic processes on the sustainability of biogenic reefs. Continental Shelf Research 29, 1605-1623.

Aziz, N.B.T., Inayatullah, O., Zamin, M. \& Jusoh, M. 2013. The mechanism of mangrove tree in wave energy propagation. Advanced Materials Research 615, 568-572.

Baars, J.R., Coetzee, J.A., Martin, G., Hill, M.P. \& Caffrey, J.M. 2010. Natural enemies from South Africa for biological control of Lagarosiphon major (Ridl.) Moss ex Wager (Hydrocharitaceae) in Europe. Hydrobiologia 656, 149-158.

Bacchiocchi, F. \& Airoldi, L. 2003. Distribution and dynamics of epibiota on hard structures for coastal protection. Estuarine, Coastal and Shelf Science 56, 1157-1166.

Bader, J., Mesquita, M.D.S., Hodges, K.I., Keenlyside, N., Østerhus, S. \& Miles, M. 2011. A review on Northern Hemisphere sea-ice, storminess and the North Atlantic Oscillation: observations and projected changes. Atmospheric Research 101, 809-834.

Badola, R. \& Hussain, S.A. 2005. Valuing ecosystem functions: an empirical study on the storm protection function of Bhitarkanika mangrove ecosystem, India. Environmental Conservation 32, 85-92.

Bailey, H., Senior, B., Simmons, D., Rusin, J., Picken, G. \& Thompson, P.M. 2010. Assessing underwater noise levels during pile-driving at an offshore windfarm and its potential effects on marine mammals. Marine Pollution Bulletin 60, 888-897.

Baine, M. 2001. Artificial reefs: a review of their design, application, management and performance. Ocean \& Coastal Management 44, 241-259. 


\section{OCEAN SPRAWL}

Baine, M. 2002. The North Sea rigs-to-reefs debate. ICES Journal of Marine Science 59, S277-S280.

Baker, P., Fajans, J.S., Arnold, W.S., Ingrao, D.A., Marelli, D.C. \& Baker, S.M. 2007. Range and dispersal of a tropical marine invader, the Asian green mussel, Perna viridis, in subtropical waters of the southeastern United States. Journal of Shellfish Research 26, 345-355.

Bally, R., McQuaid, C.D. \& Brown, A.C. 1984. Shores of mixed sand and rock: an unexplored marine ecosystem. South African Journal of Science 80, 500-503.

Barbier, E.B., Hacker, S.D., Kennedy, C., Koch, E.W., Stier, A.C. \& Silliman, B.R. 2011. The value of estuarine and coastal ecosystem services. Ecological Monographs 81, 169-193.

Barbier, E.B., Koch, E.W., Silliman, B.R., Hacker, S.D., Wolanski, E., Primavera, J., Granek, E.F., Polasky, S., Aswani, S., Cramer, L.A., Stoms, D.M., Kennedy, C.J., Bael, D., Kappel, C.V., Perillo, G.M.E. \& Reed, D.J. 2008. Coastal ecosystem-based management with nonlinear ecological functions and values. Science 319, 321-323.

Bates, A.E., Bird, T.J., Stuart-Smith, R.D., Wernberg, T., Sunday, J.M., Barrett, N.S., Edgar, G.J., Frusher, S., Hobday, A.J., Pecl, G.T., Smale, D.A. \& McCarthy, M. 2015. Distinguishing geographical range shifts from artefacts of detectability and sampling effort. Diversity and Distributions 21, 13-22.

Bates, A.E., Pecl, G.T., Frusher, S., Hobday, A.J., Wernberg, T., Smale, D.A., Sunday, J.M., Hill, N.A., Dulvy, N.K., Colwell, R.K., Holbrook, N.J., Fulton, E.A., Slawinski, D., Feng, M., Edgar, G.J., Radford, B.T., Thompson, P.A. \& Watson, R.A. 2014. Defining and observing stages of climate-mediated range shifts in marine systems. Global Environmental Change 26, 27-38.

Beaumont, N.J., Austen, M.C., Atkins, J.P., Burdon, D., Degraer, S., Dentinho, T.P., Derous, S., Holm, P., Horton, T., van Ierland, E., Marboe, A.H., Starkey, D.J., Townsend, M. \& Zarzycki, T. 2007. Identification, definition and quantification of goods and services provided by marine biodiversity: Implications for the ecosystem approach. Marine Pollution Bulletin 54, 253-265.

Beck, M.W., Brumbaugh, R.D., Airoldi, L., Carranza, A., Coen, L.D., Crawford, C., Defeo, O., Edgar, G.J., Hancock, B., Kay, M., Lenihan, H., Luckenbach, M.W., Toropova, C.L. \& Zhang, G. 2009. Shellfish Reefs at Risk: A Global Analysis of Problems and Solutions. Arlington, Virginia: Nature Conservancy.

Beck, M.W., Brumbaugh, R.D., Airoldi, L., Carranza, A., Coen, L.D., Crawford, C., Defeo, O., Edgar, G.J., Hancock, B., Kay, M.C., Lenihan, H.S., Luckenbach, M.W., Toropova, C.L., Zhang, G. \& Guo, X. 2011. Oyster reefs at risk and recommendations for conservation, restoration, and management. BioScience 61, 107-116.

Bellard, C., Thuiller, W., Leroy, B., Genovesi, P., Bakkenes, M. \& Courchamp, F. 2013. Will climate change promote future invasions? Global Change Biology 19, 3740-3748.

Benson, A.J. 2010. Perna viridis. USGS Nonindigenous Aquatic Species Database, Gainesville, FL. http://nas. er.usgs.gov/queries/factsheet.aspx?SpeciesID $=110$.

Berry, P.M., Dawson, T.P., Harrison, P.A. \& Pearson, R.G. 2002. Modelling potential impacts of climate accessed for all change on the bioclimatic envelope of species in Britain and Ireland. Global Ecology and Biogeography 11, 453-462.

Beven, J.L., Avila, L.A., Blake, E.S., Brown, D.P., Franklin, J.L., Knabb, R.D., Pasch, R.J., Rhome, J.R. \& Stewart, S.R. 2008. Atlantic hurricane season of 2005. Monthly Weather Review 136, 1109-1173.

Bilgili, M., Yasar, A. \& Simsek, E. 2011. Offshore wind power development in Europe and its comparison with onshore counterpart. Renewable and Sustainable Energy Reviews 15, 905-915.

Bilkovic, D.M. \& Mitchell, M.M. 2013. Ecological tradeoffs of stabilized salt marshes as a shoreline protection strategy: effects of artificial structures on macrobenthic assemblages. Ecological Engineering 61 , 469-481.

Bishop, J.D.D., Wood, C.A., Lévêque, L., Yunnie, A.L.E. \& Viard, F. 2015. Repeated rapid assessment surveys reveal contrasting trends in occupancy of marinas by non-indigenous species on opposite sides of the western English Channel. Marine Pollution Bulletin 95, 699-706.

Black, K. 2001. Artificial surfing reefs for erosion control and amenity: theory and application. Journal of Coastal Research SI 34, 1-14.

Blanchette, C.A., Melissa Miner, C., Raimondi, P.T., Lohse, D., Heady, K.E.K. \& Broitman, B.R. 2008. Biogeographical patterns of rocky intertidal communities along the Pacific coast of North America. Journal of Biogeography 35, 1593-1607.

Blight, A.J. \& Thompson, R.C. 2008. Epibiont species richness varies between holdfasts of a northern and a southerly distributed kelp species. Journal of the Marine Biological Association of the United Kingdom 88, 469-475. 


\section{LOUISE B. FIRTH ET AL.}

Bloom, D.E. 2011. 7 Billion and counting. Science 333, 562-569.

Borsje, B.W., van Wesenbeeck, B.K., Dekker, F., Paalvast, P., Bouma, T.J., van Katwijk, M.M. \& de Vries, M.B. 2011. How ecological engineering can serve in coastal protection. Ecological Engineering 37, 113-122.

Bouma, T.J., De Vries, M.B., Low, E., Peralta, G., Tánczos, I.C., van de Koppel, J. \& Herman, P.M.J. 2005. Trade-offs related to ecosystem engineering: a case study on stiffness of emerging macrophytes. Ecology 86, 2187-2199.

Bouma, T.J., van Belzen, J., Balke, T., Zhu, Z., Airoldi, L., Blight, A.J., Davies, A.J., Galvan, C., Hawkins, S.J., Hoggart, S.P.G., Lara, J.L., Losada, I.J., Maza, M., Ondiviela, B., Skov, M.W., Strain, E.M., Thompson, R.C., Yang, S., Zanuttigh, B., Zhang, L. \& Herman, P.M.J. 2014. Identifying knowledge gaps hampering application of intertidal habitats in coastal protection: opportunities and steps to take. Coastal Engineering 87, 147-157.

Bouma, T.J., Vries, M.B.D. \& Herman, P.M.J. 2010. Comparing ecosystem engineering efficiency of two plant species with contrasting growth strategies. Ecology 91, 2696-2704.

Bracewell, S.A., Robinson, L.A., Firth, L.B. \& Knights, A.M. 2013. Predicting free-space occupancy on novel artificial structures by an invasive intertidal barnacle using a removal experiment. PLoS ONE 8, e74457.

Bracewell, S.A., Spencer, M., Marrs, R.H., Iles, M. \& Robinson, L.A. 2012. Cleft, crevice, or the inner thigh: 'Another Place' for the establishment of the invasive barnacle Austrominius modestus (Darwin, 1854). PLOS ONE 7, e48863.

Broitman, B.R., Mieszkowska, N., Helmuth, B. \& Blanchette, C.A. 2008. Climate and recruitment of rocky shore intertidal invertebrates in the eastern North Atlantic. Ecology 89, S81-S90.

Brooks, S.M. \& Spencer, T. 2012. Shoreline retreat and sediment release in response to accelerating sea level rise: measuring and modelling cliffline dynamics on the Suffolk Coast, UK. Global and Planetary Change 80-81, 165-179.

Brown, S., Barton, M.E. \& Nicholls, R.J. 2014. Shoreline response of eroding soft cliffs due to hard defences. Proceedings of the ICE-Maritime Engineering 167, 3-14.

Browne, M. \& Chapman, M.G. 2014. Mitigating against the loss of species by adding artificial intertidal pools to existing seawalls. Marine Ecology Progress Series 497, 119-129.

Browne, M.A. \& Chapman, M.G. 2011. Ecologically informed engineering reduces loss of intertidal biodiversity on artificial shorelines. Environmental Science \& Technology 45, 8204-8207.

Buck, B.H., Krause, G., Michler-Cieluch, T., Brenner, M., Buchholz, C.M., Busch, J.A., Fisch, R., Geisen, M. \& Zielinski, O. 2008. Meeting the quest for spatial efficiency: progress and prospects of extensive aquaculture within offshore wind farms. Helgoland Marine Research 62, 269-281.

Bull, A.S. 1989. Some comparisons between communities beneath petroleum platforms off California and in the Gulf of Mexico. In Petroleum Structures as Artificial Reefs: A Compendium. Proceedings of the Fourth International Conference on Artificial Habitats for Fisheries, Rigs to Reefs Special Session, Miami, FL, November 4, 1987, V.C. Reggio Jr. (ed.). OCS Study/NMS 89-0021, 47-50. alga, Codium fragile ssp. tomentosoides, in the north Adriatic Sea. Journal of Applied Ecology 42, 1063-1072.

Bulleri, F., Balata, D., Bertocci, I., Tamburello, L. \& Benedetti-Cecchi, L. 2010. The seaweed Caulerpa racemosa on Mediterranean rocky reefs: from passenger to driver of ecological change. Ecology 91, 2205-2212.

Bulleri, F. \& Chapman, M.G. 2004. Intertidal assemblages on artificial and natural habitats in marinas on the north-west coast of Italy. Marine Biology 145, 381-391.

Bulleri, F. \& Chapman, M.G. 2010. The introduction of coastal infrastructure as a driver of change in marine environments. Journal of Applied Ecology 47, 26-35.

Burcharth, H.F., Hawkins, S.J., Zanuttigh, B. \& Lamberti, A. 2007. Environmental Design Guidelines for Low Crested Coastal Structures. London: Elsevier.

Burrows, M.T., Harvey, R., Robb, L., Poloczanska, E.S., Mieszkowska, N., Moore, P., Leaper, R., Hawkins, S.J. \& Bennedetti-Cecci, L. 2008. Spatial scales of variance in distributions of intertidal species on complex coastlines: effects of region, dispersal mode and trophic level. Ecology 90, 1242-1254.

Burrows, M.T., Schoeman, D.S., Buckley, L.B., Moore, P., Poloczanska, E.S., Brander, K.M., Brown, C., Bruno, J.F., Duarte, C.M., Halpern, B.S., Holding, J., Kappel, C.V., Kiessling, W., O’Connor, M.I., Pandolfi, J.M., Parmesan, C., Schwing, F.B., Sydeman, W.J. \& Richardson, A.J. 2011. The pace of shifting climate in marine and terrestrial ecosystems. Science 334, 652-655. 


\section{OCEAN SPRAWL}

Burt, J., Bartholomew, A. \& Sale, P.F. 2011. Benthic development on large-scale engineered reefs: a comparison of communities among breakwaters of different age and natural reefs. Ecological Engineering 37, 191-198.

Burt, J., Bartholomew, A., Usseglio, P., Bauman, A. \& Sale, P.F. 2009. Are artificial reefs surrogates of natural habitats for corals and fish in Dubai, United Arab Emirates? Coral Reefs 28, 663-675.

Burt, J.A., Feary, D.A., Cavalcante, G., Bauman, A.G. \& Usseglio, P. 2013. Urban breakwaters as reef fish habitat in the Persian Gulf. Marine Pollution Bulletin 72, 342-350.

Byrnes, J.E., Reed, D.C., Cardinale, B.J., Cavanaugh, K.C., Holbrook, S.J. \& Schmitt, R.J. 2011. Climate-driven increases in storm frequency simplify kelp forest food webs. Global Change Biology 17, 2513-2524.

Caffrey, J., Millane, M., Evers, S. \& Moran, H. 2011. Management of Lagarosiphon major (Ridley) moss in Lough Corrib-a review. Biology and Environment: Proceedings of the Royal Irish Academy 111B, 205-212.

Caffrey, J.M., Millane, M., Evers, S., Moran, H. \& Butler, M. 2010. A novel approach to aquatic weed control and habitat restoration using biodegradable jute matting. Aquatic Invasions 5, 123-129.

Caine, E.A. 1987. Potential effect of floating dock communities on a South Carolina estuary. Journal of Experimental Marine Biology and Ecology 108, 83-91.

Callaway, J. \& Josselyn, M. 1992. The introduction and spread of smooth cordgrass (Spartina alterniflora) in South San Francisco Bay. Estuaries 15, 218-226.

Callier, M.D., Lefebvre, S., Dunagan, M.K., Bataille, M.P., Coughlan, J. \& Crowe, T.P. 2013. Shift in benthic assemblages and organisms' diet at salmon farms: community structure and stable isotope analyses. Marine Ecology Progress Series 483, 153-167.

Carr, M.H. \& Hixon, M.A. 1997. Artificial reefs: the importance of comparisons with natural reefs. Fisheries 22, 28-33.

Carstensen, J., Henriksen, O.D. \& Teilmann, J. 2006. Impacts of offshore wind farm construction on harbour porpoises: acoustic monitoring of echolocation activity using porpoise detectors (T-PODs). Marine Ecology Progress Series 321, 295-308.

Carver, C.E., Chisholm, A. \& Mallet, A.L. 2003. Strategies to mitigate the impact of Ciona intestinalis (L.) biofouling on shellfish production. Journal of Shellfish Research 22, 621-631.

Cerrano, C., Bavestrello, G., Bianchi, C.N., Cattaneo-vietti, R., Bava, S., Morganti, C., Morri, C., Picco, P., Sara, G., Schiaparelli, S., Siccardi, A. \& Sponga, F. 2000. A catastrophic mass-mortality episode of gorgonians and other organisms in the Ligurian Sea (North-western Mediterranean), summer 1999. Ecology Letters 3, 284-293.

Chapman, J. \& Regan, F. 2012. Nanofunctionalized superhydrophobic antifouling coatings for environmental sensor applications-advancing deployment with answers from nature. Advanced Engineering Materials 14, B175-B184.

Chapman, M.G. 2003. Paucity of mobile species on constructed seawalls: effects of urbanization on biodiversity. Marine Ecology Progress Series 264, 21-29.

Chapman, M.G. 2006. Intertidal seawalls as habitats for molluscs. Journal of Molluscan Studies 72, $247-257$.

Chapman, M.G. \& Blockley, D.J. 2009. Engineering novel habitats on urban infrastructure to increase intertidal biodiversity. Oecologia 161, 625-635.

Chapman, M.G. \& Bulleri, F. 2003. Intertidal seawalls—new features of landscape in intertidal environments. Landscape and Urban Planning 62, 159-172.

Chapman, M.G., People, J. \& Blockley, D. 2005. Intertidal assemblages associated with natural Corallina turf and invasive mussel beds. Biodiversity \& Conservation 14, 1761-1776.

Chapman, M.G. \& Underwood, A.J. 2011. Evaluation of ecological engineering of 'armoured' shorelines to improve their value as habitat. Journal of Experimental Marine Biology and Ecology 400, 302-313.

Chapman, M.G., Underwood, A.J. \& Blockley, D. 2008. Effects of method of deployment of artificial units of habitat on microgastropod colonization. Marine Ecology Progress Series 366, 49-57.

Charbonnel, E., Serre, C., Ruitton, S., Harmelin, J.-G. \& Jensen, A. 2002. Effects of increased habitat complexity on fish assemblages associated with large artificial reef units (French Mediterranean coast). ICES Journal of Marine Science 59, S208-S213.

Charlier, R.H., Chaineux, M.-C.P. \& Morcos, S. 2005. Panorama of the history of coastal protection. Journal of Coastal Research 21, 79-111.

Cheung, W.W.L., Lam, V.W.Y., Sarmiento, J.L., Kearney, K., Watson, R. \& Pauly, D. 2009. Projecting global marine biodiversity impacts under climate change scenarios. Fish and Fisheries 10, 235-251. 


\section{LOUISE B. FIRTH ET AL.}

Chou, L. 2006. Marine habitats in one of the world's busiest harbours. In The Environment in Asia Pacific Harbours, E. Wolanski (ed.). Dordrecht, the Netherlands: Springer Netherlands, 377-391.

Chou, L.M. 1997. Artificial reefs of Southeast Asia-do they enhance or degrade the marine environment? Environmental Monitoring and Assessment 44, 45-52.

Chou, L.M. \& Lim, T.M. 1986. A preliminary study of the coral community on artificial and natural substrates. Malayan Nature Journal 39, 225-229.

Chow, J., Kopp, R.J. \& Portney, P.R. 2003. Energy resources and global development. Science 302, 1528-1531.

Christianen, M.J.A., van Belzen, J., Herman, P.M.J., van Katwijk, M.M., Lamers, L.P.M., van Leent, P.J.M. \& Bouma, T.J. 2013. Low-canopy seagrass beds still provide important coastal protection services. PLoS ONE 8, e62413.

Chung, I., Beardall, J., Mehta, S., Sahoo, D. \& Stojkovic, S. 2011. Using marine macroalgae for carbon sequestration: a critical appraisal. Journal of Applied Phycology 23, 877-886.

Cinner, J.E., McClanahan, T.R., MacNeil, M.A., Graham, N.A.J., Daw, T.M., Mukminin, A., Feary, D.A., Rabearisoa, A.L., Wamukota, A., Jiddawi, N., Campbell, S.J., Baird, A.H., Januchowski-Hartley, F.A., Hamed, S., Lahari, R., Morove, T. \& Kuange, J. 2012. Co-management of coral reef social-ecological systems. Proceedings of the National Academy of Sciences of the United States of America 109, 5219-5222.

Clark, S. \& Edwards, A.J. 1994. Use of artificial reef structures to rehabilitate reef flats degraded by coral mining in the Maldives. Bulletin of Marine Science 55, 724-744.

Clynick, B.G. 2008. Harbour swimming nets: a novel habitat for seahorses. Aquatic Conservation: Marine and Freshwater Ecosystems 18, 483-492.

Cochard, R., Ranamukhaarachchi, S.L., Shivakoti, G.P., Shipin, O.V., Edwards, P.J. \& Seeland, K.T. 2008. The 2004 tsunami in Aceh and Southern Thailand: a review on coastal ecosystems, wave hazards and vulnerability. Perspectives in Plant Ecology, Evolution and Systematics 10, 3-40.

Collins, K.J., Jensen, A.C., Lockwood, A.P.M. \& Lockwood, S.J. 1994. Coastal structures, waste materials and fishery enhancement. Bulletin of Marine Science 55, 1240-1250.

Collins, K.J., Jensen, A.C., Mallinson, J.J., Roenelle, V. \& Smith, I.P. 2002. Environmental impact assessment of a scrap tyre artificial reef. ICES Journal of Marine Science 59, S243-S249.

Colombini, I., Chelazzi, L., Gibson, R.N. \& Atkinson, R.J.A. 2003. Influence of marine allochthonous input on sandy beach communities. Oceanography and Marine Biology: An Annual Review 41, 115-159.

Condon, R.H., Duarte, C.M., Pitt, K.A., Robinson, K.L., Lucas, C.H., Sutherland, K.R., Mianzan, H.W., Bogeberg, M., Purcell, J.E., Decker, M.B., Uye, S.-I., Madin, L.P., Brodeur, R.D., Haddock, S.H.D., Malej, A., Parry, G.D., Eriksen, E., Quiñones, J., Acha, M., Harvey, M., Arthur, J.M. \& Graham, W.M. 2013. Recurrent jellyfish blooms are a consequence of global oscillations. Proceedings of the National Academy of Sciences of the United States of America 110, 1000-1005.

Conlan, K., White, K.N. \& Hawkins, S.J. 1992. The hydrography and ecology of a re-developed brackishwater dock. Estuarine, Coastal and Shelf Science 35, 435-452.

Connell, S.D. 1999. Effects of surface orientation on the cover of epibiota. Biofouling 14, 219-226.

Connell, S.D. \& Glasby, T.M. 1999. Do urban structures influence local abundance and diversity of subtidal epibiota? A case study from Sydney Harbour, Australia. Marine Environmental Research 47, 373-387.

Connell, S.D. \& Irving, A.D. 2008. Integrating ecology with biogeography using landscape characteristics: a case study of subtidal habitat across continental Australia. Journal of Biogeography 35, 1608-1621.

Cook, R., Fariñas-Franco, J.M., Gell, F.R., Holt, R.H.F., Holt, T., Lindenbaum, C., Porter, J.S., Seed, R., Skates, L.R., Stringell, T.B. \& Sanderson, W.G. 2013. The substantial first impact of bottom fishing on rare biodiversity hotspots: a dilemma for evidence-based conservation. PLoS ONE 8, e69904.

Coombes, M.A. 2014. Chapter 5. The rock coast of the British Isles: weathering and biogenic processes. Geological Society, London, Memoirs 40, 57-76.

Coombes, M.A., La Marca, E.C., Naylor, L.A. \& Thompson, R.C. 2015. Getting into the groove: opportunities to enhance the ecological value of hard coastal infrastructure using fine-scale surface textures. Ecological Engineering 77, 314-323.

Cooper, N., Cooper, T. \& Burd, F. 2001. 25 years of salt marsh erosion in Essex: implications for coastal defence and nature conservation. Journal of Coastal Conservation 7, 31-40.

Costanza, R., D’Arge, R., De Groot, R., Farber, S., Grasso, M., Hannon, B., Limburg, K., Naeem, S., O’Neill, R.V., Paruelo, J., Raskin, R.G., Sutton, P. \& Van Den Belt, M. 1997. The value of the world's ecosystem services and natural capital. Nature 387, 253-260. 
Costanza, R., Pérez-Maqueo, O., Martinez, M.L., Sutton, P., Anderson, S.J. \& Mulder, K. 2008. The value of coastal wetlands for hurricane protection. AMBIO: A Journal of the Human Environment 37, 241-248.

Coutts, A.D.M. \& Forrest, B.M. 2007. Development and application of tools for incursion response: lessons learned from the management of the fouling pest Didemnum vexillum. Journal of Experimental Marine Biology and Ecology 342, 154-162.

Crain, C.M., Halpern, B.S., Beck, M.W. \& Kappel, C.V. 2009. Understanding and managing human threats to the coastal marine environment. Annals of the New York Academy of Sciences 1162, 39-62.

Creel, L. 2003. Ripple Effects: Population and Coastal Regions. Washington, D.C.: Population Reference Bureau.

Crickenberger, S. \& Moran, A. 2013. Rapid range shift in an introduced tropical marine invertebrate. PLoS ONE 8, e78008.

Crisp, D.J. \& Southward, A.J. 1958. The distribution of intertidal organisms along the coasts of the English Channel. Journal of the Marine Biological Association of the United Kingdom 37, 157-203.

Critchley, A.T., Farnham, W.F. \& Morrell, S.L. 1986. An account of the attempted control of an introduced marine alga, Sargassum muticum, in Southern England. Biological Conservation 35, 313-332.

Crooks, J.A., Chang, A.L. \& Ruiz, G.M. 2011. Aquatic pollution increases the relative success of invasive species. Biological Invasions 13, 165-176.

Dafforn, K.A., Glasby, T.M., Airoldi, L., Rivero, N.K., Mayer-Pinto, M. \& Johnston, E.L. 2015a. Marine urbanization: an ecological framework for designing multifunctional artificial structures. Frontiers in Ecology and the Environment 13, 82-90.

Dafforn, K.A., Glasby, T.M. \& Johnston, E.L. 2012. Comparing the invasibility of experimental 'reefs' with field observations of natural reefs and artificial structures. PLOS ONE 7, e38124.

Dafforn, K.A., Johnston, E.L. \& Glasby, T.M. 2009. Shallow moving structures promote marine invader dominance. Biofouling 25, 277-287.

Dafforn, K.A., Mayer-Pinto, M., Morris, R.L. \& Waltham, N.J. 2015b. Application of management tools to integrate ecological principles with the design of marine infrastructure. Journal of Environmental Management 158, 61-73.

Dahdouh-Guebas, F., Jayatissa, L.P., Di Nitto, D., Bosire, J.O., Lo Seen, D. \& Koedam, N. 2005. How effective were mangroves as a defence against the recent tsunami? Current Biology 15, R443-R447.

Damschen, E.I., Haddad, N.M., Orrock, J.L., Tewksbury, J.J. \& Levey, D.J. 2006. Corridors increase plant species richness at large scales. Science 313, 1284-1286.

Danielsen, F., Sørensen, M.K., Olwig, M.F., Selvam, V., Faizal Parish, F., Burgess, N.D., Hiraishi, T., Karunagaran, V.M., Rasmussen, M.S., Hansen, L.B., Quarto, A. \& Suryadiputra, N. 2005. The Asian tsunami: a protective role for coastal vegetation. Science 310, 643 only.

Davies, T.W., Jenkins, S.R., Kingham, R., Hawkins, S.J. \& Hiddink, J.G. 2012. Extirpation-resistant species do not always compensate for the decline in ecosystem processes associated with biodiversity loss. Journal of Ecology 100, 1475-1481.

Davies, T.W., Jenkins, S.R., Kingham, R., Kenworthy, J., Hawkins, S.J. \& Hiddink, J.G. 2011. Dominance, biomass and extinction resistance determine the consequences of biodiversity loss for multiple coastal ecosystem processes. PLOS ONE 6, e28362.

Davis, J., Levin, L. \& Walther, S. 2002. Artificial armored shorelines: sites for open-coast species in a southern California bay. Marine Biology 140, 1249-1262.

Day, J.W., Boesch, D.F., Clairain, E.J., Kemp, G.P., Laska, S.B., Mitsch, W.J., Orth, K., Mashriqui, H., Reed, D.J., Shabman, L., Simenstad, C.A., Streever, B.J., Twilley, R.R., Watson, C.C., Wells, J.T. \& Whigham, D.F. 2007. Restoration of the Mississippi Delta: lessons from Hurricanes Katrina and Rita. Science 315, 1679-1684.

Deegan, L.A., Johnson, D.S., Warren, R.S., Peterson, B.J., Fleeger, J.W., Fagherazzi, S. \& Wollheim, W.M. 2012. Coastal eutrophication as a driver of salt marsh loss. Nature 490, 388-392.

Denny, M.W., Hunt, L.J.H., Miller, L.P. \& Harley, C.D.G. 2009. On the prediction of extreme ecological events. Ecological Monographs 79, 397-421.

Desroy, N., Dubois, S.F., Fournier, J., Ricquiers, L., Le Mao, P., Guerin, L., Gerla, D., Rougerie, M. \& Legendre, A. 2011. The conservation status of Sabellaria alveolata (L.) (Polychaeta: Sabellariidae) reefs in the Bay of Mont-Saint-Michel. Aquatic Conservation: Marine and Freshwater Ecosystems 21, 462-471.

Dethier, M.N., McDonald, K. \& Strathmann, R.R. 2003. Colonization and connectivity of habitat patches for coastal marine species distant from source populations. Conservation Biology 17, 1024-1035. 


\section{LOUISE B. FIRTH ET AL.}

Devescovi, M. \& Iveša, L. 2008. Colonization patterns of the date mussel Lithophaga lithophaga (L., 1758) on limestone breakwater boulders of a marina. Periodicum Biologorum 110, 339-345.

de Voogd, N.J. 2007. The mariculture potential of the Indonesian reef-dwelling sponge Callyspongia (Euplacella) biru: growth, survival and bioactive compounds. Aquaculture 262, 54-64.

Diaz-Agras, G., Moreira, J., Tato, R., Garcia-Regueira, X. \& Urgorri, V. 2010. Distribution and population structure of Patella vulgata Linnaeus, 1758 (Gastropoda: Patellidae) on intertidal seawalls and rocky shores in the Ria De Ferrol (Galicia, NW Iberian Peninsula). Thalassas 26, 79-91.

Diez, J.M., D’Antonio, C.M., Dukes, J.S., Grosholz, E.D., Olden, J.D., Sorte, C.J.B., Blumenthal, D.M., Bradley, B.A., Early, R., Ibanez, I., Jones, S.J., Lawler, J.J. \& Miller, L.P. 2012. Will extreme climatic events facilitate biological invasions? Frontiers in Ecology and the Environment 10, 249-257.

Dincer, I. 1999. Environmental impacts of energy. Energy Policy 27, 845-854.

Dodds, K. 2014. Après le deluge: the UK winter storms of 2013-14. The Geographical Journal, 180, $294-296$.

Donker, J.J.A., Van der Vegt, M. \& Hoekstra, P. 2013. Wave forcing over an intertidal mussel bed. Journal of Sea Research 82, 54-66.

Doody, J.P. 2004. 'Coastal squeeze' - an historical perspective. Journal of Coastal Conservation 10, 129-138.

Doody, J.P. 2012. Sand Dune Conservation, Management and Restoration. Berlin: Springer.

Doody, J.P. 2013. Sand Dune Conservation, Management and Restoration. Dordrecht, the Netherlands: Springer.

Doyle, M.W. \& Havlick, D.G. 2009. Infrastructure and the environment. Annual Review of Environment and Resources 34, 349-373.

Drewitt, A.L. \& Langston, R.H.W. 2008. Collision effects of wind-power generators and other obstacles on birds. Annals of the New York Academy of Sciences 1134, 233-266.

Duarte, C.M., Pitt, K.A., Lucas, C.H., Purcell, J.E., Uye, S.-I., Robinson, K., Brotz, L., Decker, M.B., Sutherland, K.R., Malej, A., Madin, L., Mianzan, H., Gili, J.-M., Fuentes, V., Atienza, D., Pagés, F., Breitburg, D., Malek, J., Graham, W.M. \& Condon, R.H. 2012. Is global ocean sprawl a cause of jellyfish blooms? Frontiers in Ecology and the Environment 11, 91-97.

Dubois, S., Barillé, L. \& Cognie, B. 2009. Feeding response of the polychaete Sabellaria alveolata (Sabellariidae) to changes in seston concentration. Journal of Experimental Marine Biology and Ecology 376, 94-101.

Dubois, S., Commito, J.A., Olivier, F. \& Retière, C. 2006. Effects of epibionts on Sabellaria alveolata (L.) biogenic reefs and their associated fauna in the Bay of Mont Saint-Michel. Estuarine, Coastal and Shelf Science 68, 635-646.

Dubois, S., Retière, C. \& Olivier, F. 2002. Biodiversity associated with Sabellaria alveolata (Polychaeta: Sabellariidae) reefs: effects of human disturbances. Journal of the Marine Biological Association of the United Kingdom 82, 817-826.

Dugan, J.E., Airoldi, L., Chapman, M.G., S.J., W. \& Schlacher, T. 2011. Estuarine and coastal structures: environmental effects, a focus on shore and nearshore structures. In Treatise on Estuarine and Coastal Science, E. Wolanski \& D. McLusky (eds). Waltham, Massachusetts: Academic Press, 17-41.

Dukes, J.S. \& Mooney, H.A. 1999. Does global change increase the success of biological invaders? Trends in Ecology \& Evolution 14, 135-139.

Dumont, C.P., Gaymer, C.F. \& Thiel, M. 2011. Predation contributes to invasion resistance of benthic communities against the non-indigenous tunicate Ciona intestinalis. Biological Invasions 13, 2023-2034.

Dürr, S. \& Watson, D.I. 2010. Biofouling and antifouling in aquaculture. In Biofouling, S. Dürr \& J. Thomason (eds). London: Wiley, 267-287.

Dyson, K. \& Yocom, K. 2015. Ecological design for urban waterfronts. Urban Ecosystems 18, 189-208.

Eckman, J.E., Duggins, D.O. \& Sewell, A.T. 1989. Ecology of under story kelp environments. I. Effects of kelps on flow and particle transport near the bottom. Journal of Experimental Marine Biology and Ecology 129, 173-187.

Edwards, M., Helaouet, P., Johns, D.G., Batten, S., Beaugrand, G., Chiba, S., Hall, J., Head, E., Hosie, G., Kitchener, J., Koubbi, P., Kreiner, A., Melrose, C., Pinkerton, M., Richardson, A.J., Robinson, K., Takahashi, K., Verheye, H.M., Ward, P. \& Wootton, M. 2014. Global Marine Ecological Status Report: results from the global CPR survey 2012/2013. SAHFOS Technical Report 10, 1-37. Plymouth, UK: SAFHOS.

Elton, C.S. 1958. The Ecology of Invasions by Animals and Plants. London: Methuen. 


\section{OCEAN SPRAWL}

Emery, K.O. \& Kuhn, G.G. 1982. Sea cliffs: their processes, profiles, and classification. Geological Society of America Bulletin 93, 644-654.

Enabling the Business of Agriculture (EBA). 2011. Marine Compensation Habitat Survey Report Vancouver Convention Centre West. Technical report prepared for B.C. Pavilion Corporation (PAVCO). EBA File: V23201073. Engineering Consultants Ltd.

Espinosa, F., González, A.R., Maestre, M.J., Fa, D., Guerra-García, J.M. \& García-Gómez, J.C. 2008. Responses of the endangered limpet Patella ferruginea to reintroduction under different environmental conditions: survival, growth rates and life-history. Italian Journal of Zoology 75, 371-384.

Espinosa, F., Guerra-García, J.M., Fa, D. \& García-Gómez, J.C. 2006a. Aspects of reproduction and their implications for the conservation of the endangered limpet, Patella ferruginea. Invertebrate Reproduction \& Development 49, 85-92.

Espinosa, F., Guerra-García, J.M., Fa, D. \& García-Gómez, J.C. 2006b. Effects of competition on an endangered limpet Patella ferruginea (Gastropoda: Patellidae): implications for conservation. Journal of Experimental Marine Biology and Ecology 330, 482-492.

Esri. 2013. Interactive: the 50 largest ports in the world. http://www.smithsonianmag.com/innovation/ interactive-50-largest-ports-world-180947915/?no-ist (accessed 9 June 2015).

Eurosion. 2004. Living with coastal erosion in Europe: sediment and space for susceptibility. Part IV—a guide to coastal management practices in Europe: lessons learnt. http://www.eurosion.org/reports-online/ part4.pdf (accessed 11 May 2015).

Evans, A.J., Firth, L.B., Hawkins, S.J., Morris, E.S., Goudge, H. \& Moore, P. 2015. Drill-cored rock pools: an effective method of ecological enhancement on artificial structures. Marine and Freshwater Research 67, 123-130.

Fairweather, P.G. 1988. Movements of intertidal whelks (Morula marginalba and Thais orbita) in relation to availability of prey and shelter. Marine Biology 100, 63-68.

Falace, A., Zanelli, E. \& Bressan, G. 2006. Algal transplantation as a potential tool for artificial reef management and environmental mitigation. Bulletin of Marine Science 78, 161-166.

Fanelli, G., Piraino, S., Belmonte, G., Geraci, S. \& Boero, F. 1994. Human predation along Apulian rocky coasts (SE Italy): desertification caused by Lithophaga lithophaga (Mollusca) fisheries. Marine Ecology Progress Series 110, 1-8.

Farnham, W.F. \& Gareth-Jones, E. 1974. The eradication of the seaweed Sargassum muticum from Britain. Biological Conservation 6, 57-58.

Fauvelot, C., Bertozzi, F., Costantini, F., Airoldi, L. \& Abbiati, M. 2009. Lower genetic diversity in the limpet Patella caerulea on urban coastal structures compared to natural rocky habitats. Marine Biology 156, 2313-2323.

Fayram, A.H. \& de Risi, A. 2007. The potential compatibility of offshore wind power and fisheries: an example using bluefin tuna in the Adriatic Sea. Ocean \& Coastal Management 50, 597-605.

Feagin, R.A., Sherman, D.J. \& Grant, W.E. 2005. Coastal erosion, global sea-level rise, and the loss of sand dune plant habitats. Frontiers in Ecology and the Environment 3, 359-364.

Feary, D.A., Burt, J.A. \& Bartholomew, A. 2011. Artificial marine habitats in the Arabian Gulf: review of current use, benefits and management implications. Ocean \& Coastal Management 54, 742-749.

Fenner, D. \& Banks, K. 2004. Orange cup coral Tubastraea coccinea invades Florida and the Flower Garden Banks, northwestern Gulf of Mexico. Coral Reefs 23, 505-507.

Ferrario, F., Beck, M.W., Storlazzi, C.D., Micheli, F., Shepard, C.C. \& Airoldi, L. 2014. The effectiveness of coral reefs for coastal hazard risk reduction and adaptation. Nature Communications 5, 3794.

Firth, L. \& Crowe, T. 2008. Large-scale coexistence and small-scale segregation of key species on rocky shores. Hydrobiologia 614, 233-241.

Firth, L. \& Crowe, T. 2010. Competition and habitat suitability: small-scale segregation underpins large-scale 2 Crowe 2008 coexistence of key species on temperate rocky shores. Oecologia 162, 163-174.

Firth, L.B., Crowe, T.P., Moore, P., Thompson, R.C. \& Hawkins, S.J. 2009. Predicting impacts of climateinduced range expansion: an experimental framework and a test involving key grazers on temperate rocky shores. Global Change Biology 15, 1413-1422.

Firth, L.B. \& Hawkins, S.J. 2011. Introductory comments-global change in marine ecosystems: patterns, processes and interactions with regional and local scale impacts. Journal of Experimental Marine Biology and Ecology 400, 1-6. 


\section{LOUISE B. FIRTH ET AL.}

Firth, L.B., Knights, A.M. \& Bell, S.S. 2011. Air temperature and winter mortality: implications for the persistence of the invasive mussel, Perna viridis in the intertidal zone of the south-eastern United States. Journal of Experimental Marine Biology and Ecology 400, 250-256.

Firth, L.B., Mieszkowska, N., Grant, L., Bush, L., Davies, A.J., Frost, M.T., Cunningham, P.N., Moschella, P. \& Hawkins, S.J. 2015a. Historical comparisons reveal multiple drivers of decadal change of an ecosystem engineer at the range edge. Ecology and Evolution 5, 3210-3222.

Firth, L.B., Mieszkowska, N., Thompson, R.C. \& Hawkins, S.J. 2013a. Climate change and adaptational impacts in coastal systems: the case of sea defences. Environmental Science: Processes \& Impacts 15, 1665-1670.

Firth, L.B., Schofield, M., White, F.J., Skov, M.W. \& Hawkins, S.J. 2014a. Biodiversity in intertidal rock pools: informing engineering criteria for artificial habitat enhancement in the built environment. Marine Environmental Research 102, 122-130.

Firth, L.B., Thompson, R.C., Bohn, K., Abbiati, M., Airoldi, L., Bouma, T.J., Bozzeda, F., Ceccherelli, V.U., Colangelo, M.A., Evans, A., Ferrario, F., Hanley, M.E., Hinz, H., Hoggart, S.P.G., Jackson, J.E., Moore, P., Morgan, E.H., Perkol-Finkel, S., Skov, M.W., Strain, E.M., van Belzen, J. \& Hawkins, S.J. 2014 b. Between a rock and a hard place: environmental and engineering considerations when designing coastal defence structures. Coastal Engineering 87, 122-135.

Firth, L.B., Thompson, R.C., White, F.J., Schofield, M., Skov, M.W., Hoggart, S.P.G., Jackson, J., Knights, A.M. \& Hawkins, S.J. 2013b. The importance of water-retaining features for biodiversity on artificial intertidal coastal defence structures. Diversity and Distributions 19, 1275-1283.

Firth, L.B., White, F.J., Schofield, M., Hanley, M.E., Burrows, M.T., Thompson, R.C., Skov, W.W., Evans, A.J., Moore, P.J. \& Hawkins, S.J. 2015b. The importance of aspect for biodiversity in rocky intertidal habitats: implications for ecoloigcal engineering of the built environment. Marine and Freshwater Research 67, 131-143.

Firth, L.B. \& Williams, G.A. 2009. The influence of multiple environmental stressors on the limpet Cellana toreuma during the summer monsoon season in Hong Kong. Journal of Experimental Marine Biology and Ecology 375, 70-75.

Fischer, T.B., Kidd, S., Jha-Thakur, U., Gazzola, P. \& Peel, D. 2009. Learning through EC directive based SEA in spatial planning? Evidence from the Brunswick region in Germany. Environmental Impact Assessment Review 29, 421-428.

Fitridge, I., Dempster, T., Guenther, J. \& de Nys, R. 2012. The impact and control of biofouling in marine aquaculture: a review. Biofouling 28, 649-669.

Fletcher, L.M., Forrest, B.M. \& Bell, J.J. 2013. Impacts of the invasive ascidian Didemnum vexillum on greenlipped mussel Perna canaliculus aquaculture in New Zealand. Aquaculture Environment Interactions 4, 17-30.

Fletcher, S., Bateman, P. \& Emery, A. 2011. The governance of the Boscombe Artificial Surf Reef, UK. Land Use Policy 28, 395-401.

Floerl, O. \& Inglis, G. 2005. Starting the invasion pathway: the interaction between source populations and human transport vectors. Biological Invasions 7, 589-606.

Floerl, O., Inglis, G.J., Dey, K. \& Smith, A. 2009. The importance of transport hubs in stepping-stone invasions. Journal of Applied Ecology 46, 37-45.

Fonseca, M.S. \& Cahalan, J.A. 1992. A preliminary evaluation of wave attenuation by four species of seagrass. Estuarine, Coastal and Shelf Science 35, 565-576.

Forrest, B.M., Fletcher, L.M., Atalah, J., Piola, R.F. \& Hopkins, G.A. 2013. Predation limits spread of Didemnum vexillum into natural habitats from refuges on anthropogenic structures. PLoS ONE 8, e82229.

Forrest, B.M. \& Hopkins, G.A. 2013. Population control to mitigate the spread of marine pests: insights from management of the Asian kelp Undaria pinnatifida and colonial ascidian Didemnum vexillum. Management of Biological Invasions 4, 317-326.

Foster, N.M., Hudson, M.D., Bray, S. \& Nicholls, R.J. 2013. Intertidal mudflat and saltmarsh conservation and sustainable use in the UK: a review. Journal of Environmental Management 126, 96-104.

Francis, R. \& Hoggart, S.P.G. 2009. Urban river wall habitat and vegetation: observations from the River Thames through central London. Urban Ecosystems 12, 465-485.

Francis, R.A. \& Hoggart, S.P.G. 2008. Waste not, want not: the need to utilize existing artificial structures for habitat improvement along urban rivers. Restoration Ecology 16, 373-381. 


\section{OCEAN SPRAWL}

Gaines, S.D. \& Bertness, M.D. 1992. Dispersal of juveniles and variable recruitment in sessile marine species. Nature 360, 579-580.

Gao, Q.-F., Shin, P.K.S., Xu, W.Z. \& Cheung, S.G. 2008. Amelioration of marine farming impact on the benthic environment using artificial reefs as biofilters. Marine Pollution Bulletin 57, 652-661.

García-Gómez, J.C., Guerra-García, J.M., Espinosa, F., Maestre, M.J., Rivera-Ingraham, G., Fa, D., González, A.R., Ruiz-Tabares, A. \& López-Fé, C.M. 2014. Artificial marine micro-reserves networks (AMMRNs): an innovative approach to conserve marine littoral biodiversity and protect endangered species. Marine Ecology 36, 259-277.

García-Gómez, J.C., López-Fé, C.M., Espinosa, F., Guerra-García, J.M. \& Rivera-Ingraham, G.A. 2011. Marine artificial micro-reserves: a possibility for the conservation of endangered species living on artificial substrata. Marine Ecology 32, 6-14.

Garrabou, J., Perez, T., Sartoretto, S. \& Harmelin, J.G. 2001. Mass mortality event in red coral Corallium rubrum populations in the Provence region (France, NW Mediterranean). Marine Ecology Progress Series 217, 263-272.

Gass, S.E. \& Roberts, J.M. 2006. The occurrence of the cold-water coral Lophelia pertusa (Scleractinia) on oil and gas platforms in the North Sea: colony growth, recruitment and environmental controls on distribution. Marine Pollution Bulletin 52, 549-559.

Gaylord, B. \& Gaines, S.D. 2000. Temperature or transport? Range limits in marine species mediated solely by flow. The American Naturalist 155, 769-789.

Gaylord, B., Rosman, J.H., Reed, D.C., Koseff, J.R., Fram, J., MacIntyre, S., Arkema, K., McDonald, C., Brzezinski, M.A., Largier, J.L., Monismith, S.G., Raimondi, P.T. \& Mardian, B. 2007. Spatial patterns of flow and their modification within and around a giant kelp forest. Limnology and Oceanography $\mathbf{5 2}$, 1838-1852.

Gedan, K., Kirwan, M., Wolanski, E., Barbier, E. \& Silliman, B. 2011. The present and future role of coastal wetland vegetation in protecting shorelines: answering recent challenges to the paradigm. Climatic Change 106, 7-29.

Gedan, K.B., Silliman, B.R. \& Bertness, M.D. 2009. Centuries of human-driven change in salt marsh ecosystems. Annual Review of Marine Science 1, 117-141.

Gerland, P., Raftery, A.E., Sevcikova, H., Li, N., Gu, D.A., Spoorenberg, T., Alkema, L., Fosdick, B.K., Chunn, J., Lalic, N., Bay, G., Buettner, T., Heilig, G.K. \& Wilmoth, J. 2014. World population stabilization unlikely this century. Science 346, 234-237.

Gill, A.B. 2005. Offshore renewable energy: ecological implications of generating electricity in the coastal zone. Journal of Applied Ecology 42, 605-615.

Gkoumas, K., Petrini, F. \& Bontempi, F. 2013. Energy harvesting for the life-cycle of structures and infrastructures: state of art, recent trends and future developments. In Life-Cycle and Sustainability of Civil Infrastructure Systems, Proceedings of the Third International Symposium on Life-Cycle Civil Engineering, (IALCCE'12), Vienna, Austria, October 3-6 2012, A. Strauss et al. (eds), 2012-2109.

Glasby, T. Connell, S. Holloway, M. \& Hewitt, C. 2007. Non-indigenous biota on artificial structures: could lisher's name pu habitat creation facilitate biological invasions? Marine Biology 151, 887-895.

Glasby, T.M. 1999. Differences between subtidal epibiota on pier pilings and rocky reefs at marinas in Sydney, Australia. Estuarine, Coastal and Shelf Science 48, 281-290.

Global Wind Energy Council (GWEC). 2014. Global wind report 2014-annual market update. http://www. gwec.net/publications/global-wind-report-2/global-wind-report-2014-annual-market-update/ (accessed 15 June 2015).

Goldstien, S.J., Schiel, D.R. \& Gemmell, N.J. 2006. Comparative phylogeography of coastal limpets across a marine disjunction in New Zealand. Molecular Ecology 15, 3259-3268.

Goodsir, F., Bloomfield, H.J., Judd, A., Kral, F., Robinson, L.A. \& Knights, A.M. 2015. A spatially-resolved pressure-based approach to evaluate combined effects of human activities and management in marine ecosystems. ICES Journal of Marine Science 72, 2245-2256.

Govaerts, A. \& Lauwaert, B. 2009. Assessment of the impact of coastal defence structures. Publication number 435/2009. London: OSPAR Commission.

Graham, W.M., Gelcich, S., Robinson, K.L., Duarte, C.M., Brotz, L., Purcell, J.E., Madin, L.P., Mianzan, H., Sutherland, K.R., Uye, S.-i., Pitt, K.A., Lucas, C.H., Bøgeberg, M., Brodeur, R.D. \& Condon, R.H. 2014. Linking human well-being and jellyfish: ecosystem services, impacts, and societal responses. Frontiers in Ecology and the Environment 12, 515-523. 


\section{LOUISE B. FIRTH ET AL.}

Gregory, K.J. 2010. The Earth's Land Surface: Landforms and Processes in Geomorphology. New York: Sage.

Griffith, K., Mowat, S., Holt, R.H., Ramsay, K., Bishop, J.D., Lambert, G. \& Jenkins, S.R. 2009. First records in Great Britain of the invasive colonial ascidian Didemnum vexillum Kott, 2002. Aquatic Invasions 4 , 581-590.

Griffiths, C.L., Hockey, P.A.R., Van Erkom Schurink, C. \& Le Roux, P.J. 1992. Marine invasive aliens on South African shores: implications for community structure and trophic functioning. South African Journal of Marine Science 12, 713-722.

Grozea, C.M. \& Walker, G.C. 2009. Approaches in designing non-toxic polymer surfaces to deter marine biofouling. Soft Matter 5, 4088-4100.

Guan, D.M. 2013. Study on the National Marine Function Zonation [in Chinese]. Beijing: Ocean Press.

Guerra-García, J.M., Corzo, J., Espinosa, F. \& García-Gómez, J.C. 2004. Assessing habitat use of the endangered marine mollusc Patella ferruginea (Gastropoda, Patellidae) in northern Africa: preliminary results and implications for conservation. Biological Conservation 116, 319-326.

Gutzler, B.C., Butler, M.J. \& Behringer, D.C. 2015. Casitas: a location-dependent ecological trap for juvenile Caribbean spiny lobsters, Panulirus argus. ICES Journal of Marine Science 72 (Suppl. 1), 177-184.

Halpern, B.S., Walbridge, S., Selkoe, K.A., Kappel, C.V., Micheli, F., D’Agrosa, C., Bruno, J.F., Casey, K.S., Ebert, C., Fox, H.E., Fujita, R., Heinemann, D., Lenihan, H.S., Madin, E.M.P., Perry, M.T., Selig, E.R., Spalding, M., Steneck, R. \& Watson, R. 2008. A global map of human impact on marine ecosystems. Science 319, 948-952.

Hamzah, B.A. 2003. International rules on decommissioning of offshore installations: some observations. Marine Policy 27, 339-348.

Hanley, M.E., Hoggart, S.P.G., Simmonds, D.J., Bichot, A., Colangelo, M.A., Bozzeda, F., Heurtefeux, H., Ondiviela, B., Ostrowski, R., Recio, M., Trude, R., Zawadzka-Kahlau, E. \& Thompson, R.C. 2014. Shifting sands? Coastal protection by sand banks, beaches and dunes. Coastal Engineering 87, 136-146.

Hanson, H., Brampton, A., Capobianco, M., Dette, H.H., Hamm, L., Laustrup, C., Lechuga, A. \& Spanhoff, R. 2002. Beach nourishment projects, practices, and objectives-a European overview. Coastal Engineering 47, 81-111.

Harley, C.D.G., Randall Hughes, A., Hultgren, K.M., Miner, B.G., Sorte, C.J.B., Thornber, C.S., Rodriguez, L.F., Tomanek, L. \& Williams, S.L. 2006. The impacts of climate change in coastal marine systems. Ecology Letters 9, 228-241.

Harris, L.E. 2009. Artificial reefs for ecosystem restoration and coastal erosion protection with aquaculture and recreational amenities. Reef Journal 1, 235-246.

Hashim, R., Kamali, B., Tamin, N.M. \& Zakaria, R. 2010. An integrated approach to coastal rehabilitation: mangrove restoration in Sungai Haji Dorani, Malaysia. Estuarine Coastal and Shelf Science 86, 118-124.

Hawkins, S.J., Allen, J.R. \& Bray, S. 1999. Restoration of temperate marine and coastal ecosystems: nudging nature. Aquatic Conservation: Marine and Freshwater Ecosystems 9, 23-46.

Hawkins, S.J., Allen, J.R., Russell, G., White, K.N., Conlan, K., Hendry, K. \& Jones, H.D. 1992a. Restoring and managing disused docks in inner city areas. In Restoring the Nation's Marine Environment, G.W. Thayer (ed.). College Park, Maryland: Schiffer, 473-542.

Hawkins, S.J., Cunningham, P.N., Dolan, B., Evans, L.C., Holmes, G.D., O’Hara, K., Russell, G., Walmsley, A. \& White, K.N. 1992b. Culture of mussels in Sandon dock, a disused dock basin in Liverpool. Journal of Medical and Applied Malacology 4, 165-178.

Hawkins, S.J., Gibbs, P.E., Pope, N.D., Burt, G.R., Chesman, B.S., Bray, S., Proud, S.V., Spence, S.K., Southward, A.J. \& Langston, W.J. 2002. Recovery of polluted ecosystems: the case for long-term studies. Marine Environmental Research 54, 215-222.

Hawkins, S.J. \& Hartnoll, R.G. 1980. A study of the small-scale relationship between species number and area on a rocky shore. Estuarine and Coastal Marine Science 10, 201-214.

Hawkins, S.J., Moore, P.J., Burrows, M.T., Poloczanska, E., Mieszkowska, N., Herbert, R.J.H., Jenkins, S.R., Thompson, R.C., Genner, M.J. \& Southward, A.J. 2008. Complex interactions in a rapidly changing world: responses of rocky shore communities to recent climate change. Climate Research 37, 123-133.

Hawkins, S.J., Southward, A.J. \& Barrett, R.L. 1983. Population structure of Patella vulgata L. during succession on rocky shores in Southwest England. Oceanologica Acta Special Issue, 103-107. 
Hawkins, S.J., Sugden, H.E., Mieszkowska, N., Moore, P.J., Poloczanska, E., Leaper, R., Herbert, R., Genner, M.J., Moschela, P.S., Thompson, R.C., Jenkins, S.R., Southward, A.J. \& Burrows, M.T. 2009. Consequences of climate-driven biodiversity changes for ecosystem functioning. Marine Ecology Progress Series 396, 245-259.

Hellmann, J.J., Byers, J.E., Bierwagen, B.G. \& Dukes, J.S. 2008. Five potential consequences of climate change for invasive species. Conservation Biology 22, 534-543.

Hellyer, C.B., Harasti, D. \& Poore, A.G.B. 2011. Manipulating artificial habitats to benefit seahorses in Sydney Harbour, Australia. Aquatic Conservation: Marine and Freshwater Ecosystems 21, 582-589.

Helmuth, B., Mieszkowska, N., Moore, P. \& Hawkins, S.J. 2006. Living on the edge of two changing worlds: forecasting the impacts of climate change on rocky intertidal ecosystems. Annual Review of Ecology, Systematics and Evolution 37, 373-404.

Helvey, M. 2002. Are southern California oil and gas platforms essential fish habitat? ICES Journal of Marine Science 59, S266-S271.

Herbert, R.J., Southward, A.J., Clarke, R.T., Sheader, M. \& Hawkins, S.J. 2009. Persistent border: an analysis of the geographic boundary of an intertidal species. Marine Ecology Progress Series 379, 135-150.

Herbert, R.J.H. 2011. Boscombe Surf Reef Colonisation Project. London: Esmee Fairbairn Trust.

Herbert, R.J.H., Hawkins, S.J., Sheader, M. \& Southward, A.J. 2003. Range extension and reproduction of text. the barnacle Balanus perforatus in the eastern English Channel. Journal of the Marine Biological Association of the United Kingdom 83, 73-82.

Herbert, R.J.H., Short, H.G., Burnard, D., Pegg, J., Ross, K.E. \& Britton, J.R. 2013. An initial investigation into the contribution of a novel artificial surf reef to sustainable fisheries. North Shields, UK: Marine Management Organisation.

Herbert, R.J.H., Southward, A.J., Sheader, M. \& Hawkins, S.J. 2007. Influence of recruitment and temperature on distribution of intertidal barnacles in the English Channel. Journal of the Marine Biological Association of the United Kingdom 87, 487-499.

Hewitt, C., Campbell, M., McEnnulty, F., Moore, K., Murfet, N., Robertson, B. \& Schaffelke, B. 2005. Efficacy of physical removal of a marine pest: the introduced kelp Undaria pinnatifida in a Tasmanian Marine Reserve. Biological Invasions 7, 251-263.

Hinkel, J., Lincke, D., Vafeidis, A.T., Perrette, M., Nicholls, R.J., Tol, R.S.J., Marzeion, B., Fettweis, X., Ionescu, C. \& Levermann, A. 2014. Coastal flood damage and adaptation costs under 21st century sea-level rise. Proceedings of the National Academy of Sciences of the United States of America 111, 3292-3297.

Hirabayashi, Y., Mahendran, R., Koirala, S., Konoshima, L., Yamazaki, D., Watanabe, S., Kim, H. \& Kanae, S. 2013. Global flood risk under climate change. Nature Climate Change 3, 816-821.

Hirose, N., Watanuki, A. \& Saito, M. 2002. New type units for artificial reef development of eco-friendly artificial reefs and the effectiveness thereof [online]. In 30th PIANC-AIPCN Congress 2002, R.J. Cox (ed.). Sydney, Australia: Institution of Engineers, 886-899.

Hoegh-Guldberg, O., Hughes, L., McIntyre, S., Lindenmayer, D.B., Parmesan, C., Possingham, H.P. \& Thomas, C.D. 2008. Assisted colonization and rapid climate change. Science 321, 345-346.

Hoggart, S.G., Francis, R. \& Chadwick, M. 2012. Macroinvertebrate richness on flood defence walls of the tidal River Thames. Urban Ecosystems 15, 327-346.

Hoggart, S.P.G., Hanley, M.E., Parker, D.J., Simmonds, D.J., Bilton, D.T., Filipova-Marinova, M., Franklin, E.L., Kotsev, I., Penning-Rowsell, E.C., Rundle, S.D., Trifonova, E., Vergiev, S., White, A.C. \& Thompson, R.C. 2014. The consequences of doing nothing: the effects of seawater flooding on coastal zones. Coastal Engineering 87, 169-182.

Holloway, M. \& Connell, S.D. 2002. Why do floating structures create novel habitats for subtidal epibiota? Marine Ecology Progress Series 235, 43-52.

Howes, N.C., FitzGerald, D.M., Hughes, Z.J., Georgiou, I.Y., Kulp, M.A., Miner, M.D., Smith, J.M. \& Barras, J.A. 2010. Hurricane-induced failure of low salinity wetlands. Proceedings of the National Academy of Sciences of the United States of America 107, 14014-14019.

Huang, D.W. \& Roy, K. 2015. The future of evolutionary diversity in reef corals. Philosophical Transactions of the Royal Society B: Biological Sciences 370, 20140010.

Huang, X.W., Wang, W. \& Dong, Y.W. 2015. Complex ecology of China's seawall. Science 347, 1079. 


\section{LOUISE B. FIRTH ET AL.}

Hughes, D.J., Cook, E.J. \& Sayer, M.D. 2005a. Biofiltration and biofouling on artificial structures in Europe: the potential for mitigating organic impacts. Oceanography and Marine Biology: An Annual Review 43, 123-172.

Hughes, T.P., Bellwood, D.R., Folke, C., Steneck, R.S. \& Wilson, J. 2005b. New paradigms for supporting the resilience of marine ecosystems. Trends in Ecology \& Evolution 20, 380-386.

Hulme, M., Jenkins, G.J., Lu, X., Turnpenny, J.R., Mitchell, T.D., Jones, R.G., Lowe, J. 2002. Climate change scenarios for the United Kingdom: the UKCIP02 scientific report. Oxford, UK: UK Climate Impacts Programme (UKCIP).

Hunter, W.R. \& Sayer, M.D.J. 2009. The comparative effects of habitat complexity on faunal assemblages of northern temperate artificial and natural reefs. ICES Journal of Marine Science 66, 691-698.

Huntingford, C., Marsh, T., Scaife, A.A., Kendon, E.J., Hannaford, J., Kay, A.L., Lockwood, M., Prudhomme, C. Reynard, N.S., Parry, S., Lowe, J.A., Screen, J.A., Ward, H.C., Roberts, M., Stott, P. A., Bell, V.A., Bailey, M., Jenkins, A., Legg, T., Otto, F.E.L., Massey, N., Schaller, N., Slingo, J. \& Allen, M.R. 2014. Potential influences on the United Kingdom's floods of winter 2013/14. Nature Climate Change 4, 769-777.

Inger, R., Attrill, M.J., Bearhop, S., Broderick, A.C., James Grecian, W., Hodgson, D.J., Mills, C., Sheehan, E., Votier, S.C., Witt, M.J. \& Godley, B.J. 2009. Marine renewable energy: potential benefits to biodiversity? An urgent call for research. Journal of Applied Ecology 46, 1145-1153.

Intergovernmental Panel on Climate Change (IPCC). 2012. Managing the risks of extreme events and disasters to advance climate change adaptation. A special report of Working Groups I and II of the Intergovernmental Panel on Climate Change, C.B. Field et al. (eds). Cambridge, UK: Cambridge University Press.

Intergovernmental Panel on Climate Change (IPCC). 2013. Summary for policymakers. In Climate Change 2013: The Physical Science Basis. Contribution of Working Group I to the Fifth Assessment Report of the Intergovernmental Panel on Climate Change, T.F. Stocker et al. (eds). Cambridge, UK: Cambridge University Press.

Intergovernmental Panel on Climate Change (IPCC). 2014. Climate change 2014: synthesis report. Contribution of Working Groups I, II and III to the fifth assessment report of the Intergovernmental Panel on Climate Change, R. Pachauri \& L. Meyer (eds). Geneva, Switzerland: IPCC.

Irlandi, E.A. \& Crawford, M.K. 1997. Habitat linkages: the effect of intertidal saltmarshes and adjacent subtidal habitats on abundance, movement, and growth of an estuarine fish. Oecologia 110, 222-230.

Ishii, H. \& Katsukoshi, K. 2010. Seasonal and vertical distribution of Aurelia aurita polyps on a pylon in the innermost part of Tokyo Bay. Journal of Oceanography 66, 329-336.

Jackson, A.C., Chapman, M.G. \& Underwood, A.J. 2008. Ecological interactions in the provision of habitat by urban development: whelks and engineering by oysters on artificial seawalls. Austral Ecology 33, 307-316.

Jackson, A.C. \& McIlvenny, J. 2011. Coastal squeeze on rocky shores in northern Scotland and some possible ecological impacts. Journal of Experimental Marine Biology and Ecology 400, 314-321.

Jay, S., Ellis, G. \& Kidd, S. 2012. Marine spatial planning: a new frontier? Journal of Environmental Policy \& Planning 14, 1-5.

Jenkins, S.R. 2005. Larval habitat selection, not larval supply, determines settlement patterns and adult distribution in two chthamalid barnacles. Journal of Animal Ecology 74, 893-904.

Jenkins, S.R., Norton, T.A. \& Hawkins, S.J. 1999. Interactions between canopy forming algae in the eulittoral zone of sheltered rocky shores on the Isle of Man. Journal of the Marine Biological Association of the United Kingdom 79, 341-349.

Jensen, A. 1998. European artificial reef research network (EARRN): final report and recommendations. Southampton, UK: University of Southampton.

Jensen, A. 2002. Artificial reefs of Europe: perspective and future. ICES Journal of Marine Science 59, S3-S13.

Jensen, A.C., Collins, K.J. \& Lockwood, A.P.M. 2000. Artificial Reefs in European Seas. Dordrecht, the Netherlands: Kluwer Academic.

Johannesson, K. \& Warmoes, T. 1990. Rapid colonization of Belgian breakwaters by the direct developer, Littorina saxatilis (Olivi) (Prosobranchia, Mollusca). In Progress in Littorinid and Muricid Biology, K. Johannesson et al. (eds). Dordrecht, the Netherlands: Springer Netherlands, 99-108. 
Johnson, C.R., Banks, S.C., Barrett, N.S., Cazassus, F., Dunstan, P.K., Edgar, G.J., Frusher, S.D., Gardner, C., Haddon, M., Helidoniotis, F., Hill, K.L., Holbrook, N.J., Hosie, G.W., Last, P.R., Ling, S.D., MelbourneThomas, J., Miller, K., Pecl, G.T., Richardson, A.J., Ridgway, K.R., Rintoul, S.R., Ritz, D.A., Ross, D.J., Sanderson, J.C., Shepherd, S.A., Slotwinski, A., Swadling, K.M. \& Taw, N. 2011. Climate change cascades: shifts in oceanography, species' ranges and subtidal marine community dynamics in eastern Tasmania. Journal of Experimental Marine Biology and Ecology 400, 17-32.

Johnson, G.E.L., Attrill, M.J., Sheehan, E.V. \& Somerfield, P.J. 2007. Recovery of meiofauna communities following mudflat disturbance by trampling associated with crab-tiling. Marine Environmental Research 64, 409-416.

Johnson, M.P., Hughes, R.N., Burrows, M.T. \& Hawkins, S.J. 1998. Beyond the predation halo: small scale gradients in barnacle populations affected by the relative refuge value of crevices. Journal of Experimental Marine Biology and Ecology 231, 163-170.

Jones, S.J., Lima, F.P. \& Wethey, D.S. 2010. Rising environmental temperatures and biogeography: poleward range contraction of the blue mussel, Mytilus edulis L., in the western Atlantic. Journal of Biogeography 37, 2243-2259.

Jones, S.J., Mieszkowska, N. \& Wethey, D.S. 2009. Linking thermal tolerances and biogeography: Mytilus edulis (L.) at its southern limit on the east coast of the United States. The Biological Bulletin 217, 73-85.

Jones, S.J., Southward, A.J. \& Wethey, D.S. 2012. Climate change and historical biogeography of the barnacle Semibalanus balanoides. Global Ecology and Biogeography 21, 716-724.

Jongman, B., Ward, P.J. \& Aerts, J.C.J.H. 2012. Global exposure to river and coastal flooding: long term trends and changes. Global Environmental Change 22, 823-835.

Jonsson, P.R., Granhag, L., Moschella, P.S., Åberg, P., Hawkins, S.J. \& Thompson, R.C. 2006. Interactions between wave action and grazing control on the distribution of intertidal macroalgae. Ecology 87, 1169-1178.

Kaiser, M.J. \& Pulsipher, A.G. 2005. Rigs-to-Reef programs in the Gulf of Mexico. Ocean Development \& International Law 36, 119-134.

Kamali, B. \& Hashim, R. 2011. Mangrove restoration without planting. Ecological Engineering 37, 387-391.

Kamali, B., Hashim, R. \& Akib, S. 2010. Efficiency of an integrated habitat stabilisation approach to coastal erosion management. International Journal of the Physical Sciences 5, 1401-1405.

Keenan, S.F. 2002. The importance of zooplankton in the diets of blue runner (Caranx chrysos) near offshore petroleum platforms in the Northern Gulf of Mexico. MSc thesis, Louisiana State University, Baton Rouge, Louisiana.

Keith, S.A., Herbert, R.J.H., Norton, P.A., Hawkins, S.J. \& Newton, A.C. 2011. Individualistic species limitations of climate-induced range expansions generated by meso-scale dispersal barriers. Diversity and Distributions 17, 275-286.

Kench, P.S. \& Brander, R.W. 2006. Wave processes on coral reef flats: implications for reef geomorphology using Australian case studies. Journal of Coastal Research 209-223.

Kent, M., Dargie, T. \& Reid, C. 2003. The management and conservation of machair vegetation. Botanical Journal of Scotland 55, 161-176.

Kidd, S. 2007. Towards a framework of integration in spatial planning: an exploration from a health perspective. Planning Theory \& Practice 8, 161-181.

Kingsley-Smith, P.R., Joyce, R.E., Arnott, S.A., Roumillat, W.A., McDonough, C.J. \& Reichert, M.J.M. 2012. Habitat use of intertidal eastern oyster (Crassostrea virginica) reefs by nekton in South Carolina estuaries. Journal of Shellfish Research 31, 1009-1021.

Kirk, M., Esler, D. \& Boyd, S. 2007. Morphology and density of mussels on natural and aquaculture structure habitats: implications for sea duck predators. Marine Ecology Progress Series 346, 179-187.

Knights, A.M., Culhane, F., Hussain, S.S., Papadopoulou, K.N., Piet, G.J., Raakær, J., Rogers, S.I. \& Robinson, L.A. 2014. A step-wise process of decision-making under uncertainty when implementing environmental policy. Environmental Science \& Policy 39, 56-64.

Knights, A.M., Piet, G.J., Jongbloed, R.H., Tamis, J.E., White, L., Akoglu, E., Boicenco, L., Churilova, T., Kryvenko, O., Fleming-Lehtinen, V., Leppanen, J.M., Galil, B.S., Goodsir, F., Goren, M., Margonski, P., Moncheva, S., Oguz, T., Papadopoulou, K.N., Setala, O., Smith, C.J., Stefanova, K., Timofte, F. \& Robinson, L.A. 2015. An exposure-effect approach for evaluating ecosystem-wide risks from human activities. ICES Journal of Marine Science 72, 1105-1115. 


\section{LOUISE B. FIRTH ET AL.}

Knott, N.A., Underwood, A.J., Chapman, M.G. \& Glasby, T.M. 2004. Epibiota on vertical and on horizontal surfaces on natural reefs and on artificial structures. Journal of the Marine Biological Association of the United Kingdom 84, 1117-1130.

Koch, E. 2001. Beyond light: physical, geological, and geochemical parameters as possible submersed aquatic vegetation habitat requirements. Estuaries 24, 1-17.

Koch, E.W., Barbier, E.B., Silliman, B.R., Reed, D.J., Perillo, G.M.E., Hacker, S.D., Granek, E.F., Primavera, J.H., Muthiga, N., Polasky, S., Halpern, B.S., Kennedy, C.J., Kappel, C.V. \& Wolanski, E. 2009. Nonlinearity in ecosystem services: temporal and spatial variability in coastal protection. Frontiers in Ecology and the Environment 7, 29-37.

Kohata, K., Hiwatari, T. \& Hagiwara, T. 2003. Natural water-purification system observed in a shallow coastal lagoon: Matsukawa-ura, Japan. Marine Pollution Bulletin 47, 148-154.

Kolian, S.R. \& Sammarco, P.W. 2005. Mariculture and other uses for offshore platforms: rationale for retaining infrastructure. Baton Rouge, Louisiana: Eco-rigs of Eco-Endurance Center.

Lai, S., Loke, L.H.L., Hilton, M.J., Bouma, T.J. \& Todd, P.A. 2015. The effects of urbanisation on coastal habitats and the potential for ecological engineering: a Singapore case study. Ocean \& Coastal Management 103, 78-85.

Lam, N.W.Y., Huang, R. \& Chan, B.K.K. 2009. Variations in intertidal assemblages and zonation patterns between vertical artificial seawalls and natural rocky shores: a case study from Victoria Harbour, Hong Kong. Zoological Studies 48, 184-195.

Lambert, C.C. \& Lambert, G. 2003. Persistence and differential distribution of nonindigenous ascidians in harbors of the Southern California Bight. Marine Ecology Progress Series 259, 145-161.

Lamberti, A. \& Zanuttigh, B. 2005. An integrated approach to beach management in Lido di Dante, Italy. Estuarine, Coastal and Shelf Science 62, 441-451.

La Nafie, Y.A., de los Santos, C.B., Brun, F.G., van Katwijk, M.M. \& Bouma, T.J. 2012. Waves and high nutrient loads jointly decrease survival and separately affect morphological and biomechanical properties in the seagrass Zostera noltii. Limnology and Oceanography 57, 1664-1672.

Langhamer, O. 2012. Artificial reef effect in relation to offshore renewable energy conversion: state of the art. The Scientific World Journal 386713, 8.

Langhamer, O. \& Wilhelmsson, D. 2009. Colonisation of fish and crabs of wave energy foundations and the effects of manufactured holes-a field experiment. Marine Environmental Research 68, 151-157.

Langhamer, O., Wilhelmsson, D. \& Engström, J. 2009. Artificial reef effect and fouling impacts on offshore wave power foundations and buoys-a pilot study. Estuarine, Coastal and Shelf Science 82, 426-432.

Largier, J.L. 2003. Considerations in estimating larval dispersal from oceanographic data. Ecological Applications 13, 71-89.

Laubier, L. 2001. Climatic changes and trends and marine invertebrates: a need for relevant observing networks and experimental ecophysiology. Atti Associazione Italiana Oceanologia e Limnologia 14, 15-24.

Layman, C.A., Jud, Z.R., Archer, S.K. \& Riera, D. 2014. Provision of ecosystem services by human-made structures in a highly impacted estuary. Environmental Research Letters 9, 044009.

Lemos, R.T. \& Pires, H.O. 2004. The upwelling regime off the West Portuguese Coast, 1941-2000. International Journal of Climatology 24, 511-524.

Levine, J.M. \& D’Antonio, C.M. 1999. Elton revisited: a review of evidence linking diversity and invasibility. Oikos 87, 15-26.

Lewis, J.I. 2011. Building a national wind turbine industry: experiences from China, India and South Korea. International Journal of Technology and Globalisation 5, 281-305.

Lika, K., Kearney, M.R. \& Kooijman, S.A.L.M. 2011. The 'covariation method' for estimating the parameters of the standard Dynamic Energy Budget model II: properties and preliminary patterns. Journal of Sea Research 66, 278-288.

Lima, F.P., Queiroz, N., Ribeiro, P.A., Hawkins, S.J. \& Santos, A.M. 2006. Recent changes in the distribution of a marine gastropod, Patella rustica Linnaeus, 1758, and their relationship to unusual climatic events. Journal of Biogeography 33, 812-822.

Lima, F.P., Ribeiro, P.A., Queiroz, N., Hawkins, S.J. \& Santos, A.M. 2007a. Do distributional shifts of northern and southern species of algae match the warming pattern? Global Change Biology 13, 2592-2604.

Lima, F.P., Ribeiro, P.A., Queiroz, N., Xavier, R., Tarroso, P., Hawkins, S.J. \& Santos, A.M. 2007b. Modelling past and present geographical distribution of the marine gastropod Patella rustica as a tool for exploring responses to environmental change. Global Change Biology 13, 2065-2077. 


\section{OCEAN SPRAWL}

Ling, S.D. 2008. Range expansion of a habitat-modifying species leads to loss of taxonomic diversity: a new and impoverished reef state. Oecologia 156, 883-894.

Ling, S.D., Johnson, C.R., Frusher, S.D. \& Ridgway, K.R. 2009. Overfishing reduces resilience of kelp beds to climate-driven catastrophic phase shift. Proceedings of the National Academy of Sciences of the United States of America 106, 22341-22345.

Lloyd, M.J., Metaxas, A. \& deYoung, B. 2012. Patterns in vertical distribution and their potential effects on transport of larval benthic invertebrates in a shallow embayment. Marine Ecology Progress Series 469, 37-52.

Lo, W.-T., Purcell, J.E., Hung, J.-J., Su, H.-M. \& Hsu, P.-K. 2008. Enhancement of jellyfish (Aurelia aurita) populations by extensive aquaculture rafts in a coastal lagoon in Taiwan. ICES Journal of Marine Science 65, 453-461.

Loarie, S.R., Duffy, P.B., Hamilton, H., Asner, G.P., Field, C.B. \& Ackerly, D.D. 2009. The velocity of climate change. Nature 462, 1052-1055.

Loh, T.-L., Tanzil, J.T.I. \& Chou, L.M. 2006. Preliminary study of community development and scleractinian recruitment on fibreglass artificial reef units in the sedimented waters of Singapore. Aquatic Conservation: Marine and Freshwater Ecosystems 16, 61-76.

Loke, L.H.L., Jachowski, N.R., Bouma, T.J., Ladle, R.J. \& Todd, P.A. 2014. Complexity for artificial substrates (CASU): software for creating and visualising habitat complexity. PLoS ONE 9, e87990.

Loke, L.H.L., Ladle, R.J., Bouma, T.J. \& Todd, P.A. 2015. Creating complex habitats for restoration and reconciliation. Ecological Engineering 77, 307-313.

Long, H., Zou, J. \& Liu, Y. 2009. Differentiation of rural development driven by industrialization and urbanization in eastern coastal China. Habitat International 33, 454-462.

Lotze, H.K., Lenihan, H.S., Bourque, B.J., Bradbury, R.H., Cooke, R.G., Kay, M.C., Kidwell, S.M., Kirby, M.X., Peterson, C.H. \& Jackson, J.B.C. 2006. Depletion, degradation, and recovery potential of estuaries and coastal seas. Science 312, 1806-1809.

Love, M.S., Caselle, J. \& Snook, L. 1999. Fish assemblages on mussel mounds surrounding seven oil platforms in the Santa Barbara Channel and Santa Maria Basin. Bulletin of Marine Science 65, 497-513.

Lyons, D.A., Aravantidis, C., Blight, A.J., Chatzinikolaou, E., Guy-Haim, T., Kotta, J., Queirós, a.M., Rilov, G., Somerfield, P.J. \& Crowe, T.P. 2015. There are no whole truths in meta-analyses: all their truths are half truths. Global Change Biology 22, 968-971.

Maar, M., Timmermann, K., Petersen, J.K., Gustafsson, K.E. \& Storm, L.M. 2010. A model study of the regulation of blue mussels by nutrient loadings and water column stability in a shallow estuary, the Limfjorden. Journal of Sea Research 64, 322-333.

MacNeil, M.A., Graham, N.A.J., Cinner, J.E., Dulvy, N.K., Loring, P.A., Jennings, S., Polunin, N.V.C., Fisk, A.T. \& McClanahan, T.R. 2010. Transitional states in marine fisheries: adapting to predicted global change. Philosophical Transactions of the Royal Society B-Biological Sciences 365, 3753-3763.

Macreadie, P.I., Fowler, A.M. \& Booth, D.J. 2011. Rigs-to-reefs: will the deep sea benefit from artificial habitat? Frontiers in Ecology and the Environment 9, 455-461.

Maggs, C.A., Castilho, R., Foltz, D., Henzler, C., Jolly, M.T., Kelly, J., Olsen, J., Perez, K.E., Stam, W., Väinölä, R., Viard, F. \& Wares, J. 2008. Evaluating signatures of glacial refugia for north Atlantic benthic marine taxa. Ecology 89, S108-S122.

Mangan, R. \& Baars, J.-R. 2013. Use of life table statistics and degree day values to predict the colonisation success of Hydrellia lagarosiphon Deeming (Diptera: Ephydridae), a leaf mining fly of Lagarosiphon major (Ridley) Moss (Hydrocharitaceae), in Ireland and the rest of Europe. Biological Control 64, 143-151.

Manush, S.M., Pal, A.K., Das, T. \& Mukherjee, S.C. 2006. The influence of temperatures ranging from 25 to 36 degrees $\mathrm{C}$ on developmental rates, morphometrics and survival of freshwater prawn (Macrobrachium rosenbergii) embryos. Aquaculture 256, 529-536.

Marois, D.E. \& Mitsch, W.J. 2015. Coastal protection from tsunamis and cyclones provided by mangrove wetlands-a review. International Journal of Biodiversity Science, Ecosystem Services \& Management 11, 71-83.

Marshall, D.J., Monro, K., Bode, M., Keough, M.J. \& Swearer, S. 2010. Phenotype-environment mismatches reduce connectivity in the sea. Ecology Letters 13, 128-140. 


\section{LOUISE B. FIRTH ET AL.}

Martin, D., Bertasi, F., Colangelo, M.A., de Vries, M., Frost, M., Hawkins, S.J., Macpherson, E., Moschella, P.S., Satta, M.P., Thompson, R.C. \& Ceccherelli, V.U. 2005. Ecological impact of coastal defence structures on sediment and mobile fauna: evaluating and forecasting consequences of unavoidable modifications of native habitats. Coastal Engineering 52, 1027-we1051.

Martínez, M.L., Intralawan, A., Vázquez, G., Pérez-Maqueo, O., Sutton, P. \& Landgrave, R. 2007. The coasts of our world: ecological, economic and social importance. Ecological Economics 63, 254-272.

Martins, G.M., Thompson, R.C., Neto, A.I., Hawkins, S.J. \& Jenkins, S.R. 2010. Enhancing stocks of the exploited limpet Patella candei d'Orbigny via modifications in coastal engineering. Biological Conservation 143, 203-211.

Marzinelli, E.M., Underwood, A.J. \& Coleman, R.A. 2011. Modified habitats influence kelp epibiota via direct and indirect effects. PLOS ONE 6, e21936.

Marzinelli, E.M., Zagal, C.J., Chapman, M.G. \& Underwood, A.J. 2009. Do modified habitats have direct or indirect effects on epifauna? Ecology 90, 2948-2955.

Matthews, T., Murphy, C., Wilby, R.L. \& Harrigan, S. 2014. Stormiest winter on record for Ireland and UK. Nature Climate Change 4, 738-740.

Maza, M., Lara, J.L. \& Losada, I.J. 2013. A coupled model of submerged vegetation under oscillatory flow using Navier-Stokes equations. Coastal Engineering 80, 16-34.

Mazda, Y., Magi, M., Ikeda, Y., Kurokawa, T. \& Asano, T. 2006. Wave reduction in a mangrove forest dominated by Sonneratia sp. Wetlands Ecology and Management 14, 365-378.

McCann, L.D., Holzer, K.K., Davidson, I.C., Ashton, G.V., Chapman, M.D. \& Ruiz, G.M. 2013. Promoting invasive species control and eradication in the sea: options for managing the tunicate invader Didemnum vexillum in Sitka, Alaska. Marine Pollution Bulletin 77, 165-171.

McDevitt, A., Yannic, G., Rambau, R., Hayden, T. \& Searle, J. 2010. Postglacial recolonization of continental Europe by the pygmy shrew (Sorex minutus) inferred from mitochondrial and Y chromosomal DNA sequences. In Relict Species, J. Habel \& T. Assmann (eds). Berlin: Springer, 217-236.

McGranahan, G., Balk, D. \& Anderson, B. 2007. The rising tide: assessing the risks of climate change and human settlements in low elevation coastal zones. Environment and Urbanization 19, 17-37.

McKinney, M.L. 2006. Urbanization as a major cause of biotic homogenization. Biological Conservation 127, 247-260.

Mead, A., Carlton, J.T., Griffiths, C.L. \& Rius, M. 2011. Introduced and cryptogenic marine and estuarine species of South Africa. Journal of Natural History 45, 2463-2524.

Metaxas, A. \& Scheibling, R.E. 1993. Community structure and organization of tidepools. Marine Ecology Progress Series 98, 187-198.

Mieszkowska, N., Hawkins, S.J., Burrows, M.T. \& Kendall, M.A. 2007. Long-term changes in the geographic distribution and population structures of Osilinus lineatus (Gastropoda: Trochidae) in Britain and Ireland. Journal of the Marine Biological Association of the United Kingdom 87, 537-545.

Mieszkowska, N., Kendall, M.A., Hawkins, S.J., Leaper, R., Williamson, P., Hardman-Mountford, N.J. \& Southward, A.J. 2006. Changes in the range of some common rocky shore species in Britain-a response to climate change? Hydrobiologia 555, 241-251.

Mieszkowska, N. \& Lundquist, C.J. 2011. Biogeographical patterns in limpet abundance and assemblage composition in New Zealand. Journal of Experimental Marine Biology and Ecology 400, 155-166.

Mieszkowska, N., Sugden, H., Firth, L.B. \& Hawkins, S.J. 2014. The role of sustained observations in tracking impacts of environmental change on marine biodiversity and ecosystems. Philosophical Transactions of the Royal Society A: Mathematical Physical and Engineering Sciences 372, 20130339.

Millennium Ecosystem Assessment (MEA). 2005. Ecosystems and Human Well-Being. Vol. 5. Washington, D.C.: Island Press.

Miller, R.G., Hutchison, Z.L., MacLeod, A.K., Burrows, M.T., Cook, E.J., Last, K.S. \& Wilson, B. 2013. Marine renewable energy development: assessing the benthic footprint at multiple scales. Frontiers in Ecology and the Environment 11, 433-440.

Minchin, D. 2007. Rapid coastal survey for targeted alien species associated with floating pontoons in Ireland. Aquatic Invasions 2, 63-70.

Mineur, F., Cook, E.J., Minchin, D., Bohn, K., Macleod, A. \& Maggs, C.A. 2012. Changing coasts: marine aliens and artificial structures. Oceanography and Marine Biology: an Annual Review 50, 189-234. 
Mineur, F., Davies, A.J., Maggs, C.A., Verlaque, M. \& Johnson, M.P. 2010. Fronts, jumps and secondary introductions suggested as different invasion patterns in marine species, with an increase in spread rates over time. Proceedings of the Royal Society B: Biological Sciences 277, 2693-2701.

Moalic, Y., Arnaud-Haond, S., Perrin, C., Pearson, G.A. \& Serrao, E.A. 2011. Travelling in time with networks: revealing present day hybridization versus ancestral polymorphism between two species of brown algae, Fucus vesiculosus and F. spiralis. BMC Evolutionary Biology 11, 33 only.

Möller, I., Kudella, M., Rupprecht, F., Spencer, T., Paul, M., van Wesenbeeck, B.K., Wolters, G., Jensen, K., Bouma, T.J., Miranda-Lange, M. \& Schimmels, S. 2014. Wave attenuation over coastal salt marshes under storm surge conditions. Nature Geosciences 7, 727-731.

Möller, I., Mantilla-Contreras, J., Spencer, T. \& Hayes, A. 2011. Micro-tidal coastal reed beds: hydromorphological insights and observations on wave transformation from the southern Baltic Sea. Estuarine, Coastal and Shelf Science 92, 424-436.

Moore, H.B. 1934. A Comparison of the biology of Echinus esculentus in different habitats. Journal of the Marine Biological Association of the United Kingdom (New Series) 19, 869-885.

Moore, P., Hawkins, S.J. \& Thompson, R.C. 2007a. Role of biological habitat amelioration in altering the relative responses of congeneric species to climate change. Marine Ecology Progress Series 334, 11-19.

Moore, P., Thompson, R.C. \& Hawkins, S.J. 2007b. Effects of grazer identity on the probability of escapes by a canopy-forming macroalga. Journal of Experimental Marine Biology and Ecology 344, 170-180.

Moreira, J. 2006. Patterns of occurrence of grazing molluscs on sandstone and concrete seawalls in Sydney Harbour (Australia). Molluscan Research 26, 51-60.

Moreira, J., Chapman, M.G. \& Underwood, A.J. 2007. Maintenance of chitons on seawalls using crevices on sandstone blocks as habitat in Sydney Harbour, Australia. Journal of Experimental Marine Biology and Ecology 347, 134-143.

Morgan, E.H. \& Richardson, C.A. 2012. Capricious bioinvasions versus uncoordinated management strategies: how the most unlikely invaders can prosper under the current UK legislation framework. Aquatic Conservation: Marine and Freshwater Ecosystems 22, 87-103.

Morgan, S., Fisher, J., McAfee, S., Largier, J., Miller, S., Sheridan, M. \& Neigel, J. 2014. Transport of crustacean larvae between a low-inflow estuary and coastal waters. Estuaries and Coasts 37, 1269-1283.

Morgan, S.G., Fisher, J.L., Miller, S.H., McAfee, S.T. \& Largier, J.L. 2009. Nearshore larval retention in a region of strong upwelling and recruitment limitation. Ecology 90, 3489-3502.

Mork, M. 1996. Wave attenuation due to bottom vegetation. In Waves and Nonlinear Processes in Hydrodynamics, J. Grue et al. (eds). Netherlands: Springer, 371-382.

Moschella, P.S., Abbiati, M., Åberg, P., Airoldi, L., Anderson, J.M., Bacchiocchi, F., Bulleri, F., Dinesen, G.E., Frost, M., Gacia, E., Granhag, L., Jonsson, P.R., Satta, M.P., Sundelöf, A., Thompson, R.C. \& Hawkins, S.J. 2005. Low-crested coastal defence structures as artificial habitats for marine life: using ecological criteria in design. Coastal Engineering 52, 1053-1071.

Moss, R.H., Edmonds, J.A., Hibbard, K.A., Manning, M.R., Rose, S.K., van Vuuren, D.P., Carter, T.R., Emori, S., Kainuma, M., Kram, T., Meehl, G.A., Mitchell, J.F.B., Nakicenovic, N., Riahi, K., Smith, S.J., Stouffer, R.J., Thomson, A.M., Weyant, J.P. \& Wilbanks, T.J. 2010. The next generation of scenarios for climate change research and assessment. Nature 463, 747-756.

Mossman, H.L., Davy, A.J. \& Grant, A. 2012. Does managed coastal realignment create saltmarshes with 'equivalent biological characteristics' to natural reference sites? Journal of Applied Ecology 49, 1446-1456.

Mueller, C.A., Eme, J., Manzon, R.G., Somers, C.M., Boreham, D.R. \& Wilson, J.Y. 2015. Embryonic critical windows: changes in incubation temperature alter survival, hatchling phenotype, and cost of development in lake whitefish (Coregonus clupeaformis). Journal of Comparative Physiology B: Biochemical Systemic and Environmental Physiology 185, 315-331.

Mullineaux, L.S. \& Garland, E.D. 1993. Larval recruitment in response to manipulated field flows. Marine Biology 116, 667-683.

Munsch, S.H., Cordell, J.R., Toft, J.D. \& Morgan, E.E. 2014. Effects of seawalls and piers on fish assemblages and juvenile salmon feeding behavior. North American Journal of Fisheries Management 34, 814-827.

National Oceanic and Atmospheric Administration (NOAA). 2012. NOAA's state of the coast. http:// stateofthecoast.noaa.gov/population/welcome.html (accessed 25 June 2015). 


\section{LOUISE B. FIRTH ET AL.}

Naylor, L.A., Coombes, M.A. \& Viles, H.A. 2012. Reconceptualising the role of organisms in the erosion of rock coasts: a new model. Geomorphology 157-158, 17-30.

Naylor, L.A., Stephenson, W.J. \& Trenhaile, A.S. 2010. Rock coast geomorphology: recent advances and future research directions. Geomorphology 114, 3-11.

Naylor, R., Williams, S.L. \& Strong, D.R. 2001. Aquaculture-a gateway for exotic species. Science 294, 1655-1656.

Newman, R.M., Holmberg, K.L., Biesboer, D.D. \& Penner, B.G. 1996. Effects of a potential biocontrol agent, Euhrychiopsis lecontei, on Eurasian watermilfoil in experimental tanks. Aquatic Botany 53, 131-150.

Ng, C.S.L., Lim, S.C., Ong, J.Y., Teo, L.M.S., Chou, L.M., Chua, K.E. \& Tan, K.S. 2015. Enhancing the biodiversity of coastal defence structures: transplantation of nursery-reared reef biota onto intertidal seawalls. Ecological Engineering 82, 480-486.

Nicholls, R.J. \& Cazenave, A. 2010. Sea-level rise and its impact on coastal zones. Science 328, 1517-1520.

Nikolaos, N. 2004. Deep water offshore wind technologies. MSc thesis, University of Strathclyde, Department of Mechanical Engineering, Strathclyde, UK, September.

North, E.W., Schlag, Z., Hood, R.R., Li, M., Zhong, L., Gross, T. \& Kennedy, V.S. 2008. Vertical swimming behavior influences the dispersal of simulated oyster larvae in a coupled particle-tracking and hydrodynamic model of Chesapeake Bay. Marine Ecology-Progress Series 359, 99-115.

Nugues, M.M., Kaiser, M.J., Spencer, B.E. \& Edwards, D.B. 1996. Benthic community changes associated with intertidal oyster cultivation. Aquaculture Research 27, 913-924.

Nunn, J.D. 2014. Didemnum vexillum in south Galway Bay. Bulletin of the Porcupine Marine Natural History Society 2, 34-35.

Occhipinti-Ambrogi, A. 2007. Global change and marine communities: alien species and climate change. Marine Pollution Bulletin 55, 342-352.

O’Connor, M.I., Bruno, J.F., Gaines, S.D., Halpern, B.S., Lester, S.E., Kinlan, B.P. \& Weiss, J.M. 2007. Temperature control of larval dispersal and the implications for marine ecology, evolution, and conservation. Proceedings of the National Academy of Sciences of the United States of America 104, 1266-1271.

O’Connor, N.E. \& Crowe, T.P. 2005. Biodiversity loss and ecosystem functioning: distinguishing between number and identity of species. Ecology 86, 1783-1796.

Ondiviela, B., Losada, I.J., Lara, J.L., Maza, M., Galván, C., Bouma, T.J. \& van Belzen, J. 2014. The role of seagrasses in coastal protection in a changing climate. Coastal Engineering 87, 158-168.

Orr, M., Zimmer, M., Jelinski, D.E. \& Mews, M. 2005. Wrack deposition on different beach types: spatial and temporal variation in the pattern of subsidy. Ecology 86, 1496-1507.

Ortegon, K., Nies, L. \& Sutherland, J. 2012. Remanufacturing: an alternative for end of use wind turbines. In Leveraging Technology for a Sustainable World, D.A. Dornfeld \& B.S. Linke (eds). Berlin: Springer, $155-160$.

Othman, M. 1994. Value of mangroves in coastal protection. In Ecology and Conservation of Southeast Asian Marine and Freshwater Environments including Wetlands, A. Sasekumar et al. (eds). Dordrecht, the Netherlands: Springer, 277-282.

Owen, N.W., Kent, M. \& Dale, M.P. 2001. Spatial and temporal variability in seed dynamics of machair sand dune plant communities, the Outer Hebrides, Scotland. Journal of Biogeography 28, 565-588.

Page, H.M., Dugan, J.E., Culver, C.S. \& Hoesterey, J.C. 2006. Exotic invertebrate species on offshore oil platforms. Marine Ecology Progress Series 325, 101-107.

Page, H.M., Dugan, J.E., Dugan, D.S., Richards, J.B. \& Hubbard, D.M. 1999. Effects of an offshore oil platform on the distribution and abundance of commercially important crab species. Marine Ecology Progress Series 185, 47-57.

Palumbi, S.R. 2003. Population genetics, demographic connectivity, and the design of marine reserves. Ecological Applications 13, 146-158.

Parente, V., Ferreira, D., Moutinho dos Santos, E. \& Luczynski, E. 2006. Offshore decommissioning issues: deductibility and transferability. Energy Policy 34, 1992-2001.

Parmesan, C. \& Yohe, G. 2003. A globally coherent fingerprint of climate change impacts across natural systems. Nature 421, 37-42.

Passarelli, C., Olivier, F., Paterson, D.M., Meziane, T. \& Hubas, C. 2014. Organisms as cooperative ecosystem engineers in intertidal flats. Journal of Sea Research 92, 92-101. 


\section{OCEAN SPRAWL}

Patin, S. 1999. Environmental Impact of the Offshore Oil and Gas Industry. East Northport, New York: EcoMonitor.

Patten, K. \& O'Casey, C. 2007. Use of Willapa Bay, Washington, by shorebirds and waterfowl after Spartina control efforts. Journal of Field Ornithology, 78, 395-400.

Paul, M., Bouma, T.J. \& Amos, C.L. 2012. Wave attenuation by submerged vegetation: combining the effect of organism traits and tidal current. Marine Ecology Progress Series 441, 31-41.

Pearce, B., Fariñas-Franco, J.M., Wilson, C., Pitts, J., deBurgh, A. \& Somerfield, P.J. 2014. Repeated mapping of reefs constructed by Sabellaria spinulosa Leuckart 1849 at an offshore wind farm site. Continental Shelf Research 83, 3-13.

Peduzzi, P., Chatenoux, B., Dao, H., De Bono, A., Herold, C., Kossin, J., Mouton, F. \& Nordbeck, O. 2012. Global trends in tropical cyclone risk. Nature Climate Change 2, 289-294.

Pelc, R. \& Fujita, R.M. 2002. Renewable energy from the ocean. Marine Policy 26, 471-479.

Perkol-Finkel, S. \& Airoldi, L. 2010. Loss and recovery potential of marine habitats: an experimental study of factors maintaining resilience in subtidal algal forests at the Adriatic Sea. PLoS ONE 5, e10791.

Perkol-Finkel, S. \& Benayahu, Y. 2009. The role of differential survival patterns in shaping coral communities on neighboring artificial and natural reefs. Journal of Experimental Marine Biology and Ecology 369, $1-7$.

Perkol-Finkel, S., Ferrario, F., Nicotera, V. \& Airoldi, L. 2012. Conservation challenges in urban seascapes: promoting the growth of threatened species on coastal infrastructures. Journal of Applied Ecology 49, 1457-1466.

Perkol-Finkel, S., Shashar, N., Barneah, O., Ben-David-Zaslow, R., Oren, U., Reichart, T., Yacobovich, T., Yahel, G., Yahel, R. \& Benayahu, Y. 2005. Fouling reefal communities on artificial reefs: does age matter? Biofouling 21, 127-140.

Perkol-Finkel, S. \& Sella, I. 2014. Ecologically active concrete for coastal and marine infrastructure: innovative matrices and designs. In From Sea to Shore-Meeting the Challenges of the Sea, 2014, W. Allsop \& K. Burgess (eds). London: ICE, 1139-1149.

Perkol-Finkel, S. \& Sella, I. 2015. Blue is the new green-ecological enhancement of concrete based coastal and marine infrastructure. Ecological Engineering 84, 260-272 .

Perkol-Finkel, S., Shashar, N. \& Benayahu, Y. 2006. Can artificial reefs mimic natural reef communities? The roles of structural features and age. Marine Environmental Research 61, 121-135.

Perkol-Finkel, S., Zilman, G., Sella, I., Miloh, T. \& Benayahu, Y. 2008. Floating and fixed artificial habitats: spatial and temporal patterns of benthic communities in a coral reef environment. Estuarine, Coastal and Shelf Science 77, 491-500.

Perry, A.L., Low, P.J., Ellis, J.R. \& Reynolds, J.D. 2005. Climate change and distribution shifts in marine fishes. Science 308, 1912-1915.

Peters, K., Griffiths, C. \& Robinson, T.B. 2014. Patterns and drivers of marine bioinvasions in eight Western Cape harbours, South Africa. African Journal of Marine Science 36, 49-57.

Petes, L.E., Menge, B.A. \& Murphy, G.D. 2007. Environmental stress decreases survival, growth, and reproduction in New Zealand mussels. Journal of Experimental Marine Biology and Ecology 351, 83-91.

Phelps, J.J.C., Polton, J.A., Souza, A.J. \& Robinson, L.A. 2015. The influence of behaviour on larval dispersal in shelf sea gyres: Nephrops norvegicus in the Irish Sea. Marine Ecology Progress Series 518, 177-191.

Piazza, B.P., Banks, P.D. \& La Peyre, M.K. 2005. The potential for created oyster shell reefs as a sustainable shoreline protection strategy in Louisiana. Restoration Ecology 13, 499-506.

Picken, G., Baine, M., Heaps, L. \& Side, J. 2000. Rigs to Reefs in the North Sea. In Artificial Reefs in European Seas, A.C. Jensen et al. (eds). Dordrecht, the Netherlands: Springer, 331-342.

Picken, G.B. \& McIntyre, A.D. 1989. Rigs to Reefs in the North Sea. Bulletin of Marine Science 44, $782-788$.

Pickering, H. \& Whitmarsh, D. 1997. Artificial reefs and fisheries exploitation: a review of the 'attraction versus production' debate, the influence of design and its significance for policy. Fisheries Research 31, 39-59.

Pinn, E., Richardson, C.A., Thompson, R.C. \& Hawkins, S.J. 2005a. Burrow morphology, biometry, age and growth of piddocks (Mollusca: Bivalvia: Pholadidae) on the south coast of England. Marine Biology 147, 943-953.

Pinn, E.H., Mitchell, K. \& Corkill, J. 2005b. The assemblages of groynes in relation to substratum age, aspect and microhabitat. Estuarine, Coastal and Shelf Science 62, 271-282. 


\section{LOUISE B. FIRTH ET AL.}

Pinn, E.H., Thompson, R.C. \& Hawkins, S.J. 2008. Piddocks (Mollusca: Bivalvia: Pholadidae) increase topographical complexity and species diversity in the intertidal. Marine Ecology Progress Series 355, $173-182$.

Pister, B. 2009. Urban marine ecology in southern California: the ability of riprap structures to serve as rocky intertidal habitat. Marine Biology 156, 861-873.

Pitt, K.A. \& Lucas, C.H. 2014. Jellyfish Blooms. Dordrecht, the Netherlands: Springer.

Pitt, N.R., Poloczanska, E.S. \& Hobday, A.J. 2010. Climate-driven range changes in Tasmanian intertidal fauna. Marine and Freshwater Research 61, 963-970.

Pochon, X., Atalah, J., Wood, S.A., Hopkins, G.A., Watts, A. \& Boedeker, C. 2015. Cladophora ruchingeri (C. Agardh) Kützing, 1845 (Cladophorales, Chlorophyta): a new biofouling pest of green-lipped mussel Perna canaliculus (Gmelin, 1791) farms in New Zealand. Aquatic Invasions 10, 123-133.

Poloczanska, E.S., Brown, C.J., Sydeman, W.J., Kiessling, W., Schoeman, D.S., Moore, P.J., Brander, K., Bruno, J.F., Buckley, L.B., Burrows, M.T., Duarte, C.M., Halpern, B.S., Holding, J., Kappel, C.V., O’Connor, M.I., Pandolfi, J.M., Parmesan, C., Schwing, F., Thompson, S.A. \& Richardson, A.J. 2013. Global imprint of climate change on marine life. Nature Climate Change 3, 919-925.

Poloczanska, E.S., Hawkins, S.J., Southward, A.J. \& Burrows, M.T. 2008. Modeling the response of populations of competing species to climate change. Ecology 89, 3138-3149.

Poloczanska, E.S., Smith, S., Fauconnet, L., Healy, J., Tibbetts, I.R., Burrows, M.T. \& Richardson, A.J. 2011. Little change in the distribution of rocky shore faunal communities on the Australian east coast after 50 years of rapid warming. Journal of Experimental Marine Biology and Ecology 400, 145-154.

Polton, J.A. 2014. Tidally-induced mean flow over bathymetric features: a contemporary challenge for highresolution wide-area models. Geophysical and Astrophysical Fluid Dynamics 109, 207-215.

Ponti, M., Fava, F., Perlini, R.A., Giovanardi, O. \& Abbiati, M. 2015. Benthic assemblages on artificial reefs in the northwestern Adriatic Sea: does structure type and age matter? Marine Environmental Research 104, 10-19.

Poore, G.C.B. 2001. Biogeography and diversity of Australia's marine biota. In The State of the Marine Environment Report for Australia Technical Annex: 1. The Marine Environment, L.P. Zann \& P. Kailola (eds). Townsville, Queensland, Australia: Great Barrier Reef Marine Park Authority, 75-84.

Potts, T.A. \& Hulbert, A.W. 1995. Structural influences of artificial and natural habitats on fish aggregations in Onslow Bay, North Carolina. Oceanographic Literature Review 42, 588 only.

Poulakis, G., Stevens, P., Timmers, A., Stafford, C. \& Simpfendorfer, C. 2013. Movements of juvenile endangered smalltooth sawfish, Pristis pectinata, in an estuarine river system: use of non-main-stem river habitats and lagged responses to freshwater inflow-related changes. Environmental Biology of Fishes 96, 763-778.

Poulton, C.V., Lee, J., Hobbs, P., Jones, L. \& Hall, M. 2006. Preliminary investigation into monitoring coastal erosion using terrestrial laser scanning: case study at Happisburgh, Norfolk. Bulletin of the Geological Society of Norfolk 56, 45-64.

Pratolongo, P.D. 2013. The ecology of coastal wetlands. In Marine Ecology in a Changing World, A.H. Arias \& M.C. Menendez (eds). Boca Raton, Florida: CRC Press, 140-164.

Pulsipher, A.G., Iledare, O.O., Mesyanzhinov, D.V., Dupont, A. \& Zhu, Q.L. 2001. Forecasting the number of offshore platforms on the Gulf of Mexico OCS to the year 2023. OCS Study MMS 2001-013. New Orleans, Louisiana: US Department of the Interior, Minerals Management Service, Gulf of Mexico OCS Region.

Reckenbeil, B.A. \& Ozbay, G. 2014. An investigation of utilizing ripraps as substrate for oyster stocking within Delaware coastal bays. Journal of Ecosystem \& Ecography 4, 1-5.

Rekacewicz, P. \& Ahlenius, H. 2006. Coastal population and altered land cover in coastal zones (100 km of coastline). UNEP/GRID-Arendal. http://www.grida.no/graphicslib/detail/coastal-population-andaltered-land-cover-in-coastal-zones-100-km-of-coastline_7706.

Reubens, J.T., Braeckman, U., Vanaverbeke, J., Van Colen, C., Degraer, S. \& Vincx, M. 2013. Aggregation at windmill artificial reefs: CPUE of Atlantic cod (Gadus morhua) and pouting (Trisopterus luscus) at different habitats in the Belgian part of the North Sea. Fisheries Research 139, 28-34.

Reubens, J.T., Degraer, S. \& Vincx, M. 2011. Aggregation and feeding behaviour of pouting (Trisopterus luscus) at wind turbines in the Belgian part of the North Sea. Fisheries Research 108, 223-227.

Rilov, G. \& Benayahu, Y. 1998. Vertical artificial structures as an alternative habitat for coral reef fishes in disturbed environments. Marine Environmental Research 45, 431-451. 
Rius, M., Clusella-Trullas, S., McQuaid, C.D., Navarro, R.A., Griffiths, C.L., Matthee, C.A., von der Heyden, S. \& Turon, X. 2014. Range expansions across ecoregions: interactions of climate change, physiology and genetic diversity. Global Ecology and Biogeography 23, 76-88.

Rius, M., Heasman, K.G. \& McQuaid, C.D. 2011. Long-term coexistence of non-indigenous species in aquaculture facilities. Marine Pollution Bulletin 62, 2395-2403.

Rivadeneira, M.M. \& Fernández, M. 2005. Shifts in southern endpoints of distribution in rocky intertidal species along the south-eastern Pacific coast. Journal of Biogeography 32, 203-209.

Rivera-Ingraham, G.A., Espinosa, F. \& García-Gómez, J.C. 2011. Environmentally mediated sex change in the endangered limpet Patella ferruginea (Gastropoda: Patellidae). Journal of Molluscan Studies 77, $226-231$.

Robinson, D.P., Jaidah, M.Y., Jabado, R.W., Lee-Brooks, K., Nour El-Din, N.M., Malki, A.A.A., Elmeer, K., McCormick, P.A., Henderson, A.C., Pierce, S.J. \& Ormond, R.F.G. 2013. Whale sharks, Rhincodon typus, aggregate around offshore platforms in Qatari waters of the Arabian Gulf to feed on fish spawn. PLOS ONE 8, e58255.

Rooker, J.R., Dokken, Q.R., Pattengill, C.V. \& Holt, G.J. 1997. Fish assemblages on artificial and natural reefs in the Flower Garden Banks National Marine Sanctuary, USA. Coral Reefs 16, 83-92.

Rosenzweig, M.L. 2003. Win-Win Ecology: How the Earth's Species Can Survive in the Midst of Human Enterprise. Oxford, UK: Oxford University Press.

Rosman, J.H., Koseff, J.R., Monismith, S.G. \& Grover, J. 2007. A field investigation into the effects of a kelp forest (Macrocystis pyrifera) on coastal hydrodynamics and transport. Journal of Geophysical Research: Oceans 112, C02016.

Ruiz, G.M., Freestone, A.L., Fofonoff, P.W. \& Simkanin, C. 2009. Habitat distribution and heterogeneity in marine invasion dynamics: the Importance of hard substrate and artificial structure. In Marine Hard Bottom Communities, M. Wahl (ed.). Berlin: Springer, 321-332.

Ruiz, J.M., Pérez, M. \& Romero, J. 2001. Effects of fish farm loadings on seagrass (Posidonia oceanica) distribution, growth and photosynthesis. Marine Pollution Bulletin 42, 749-760.

Russell, G., Hawkins, S.J., Evans, L.C., Jones, H.D. \& Holmes, G.D. 1983. Restoration of a disused dock basin as a habitat for marine benthos and fish. Journal of Applied Ecology 20, 43-58.

Ryland, J.S., de Putron, S., Scheltema, R.S., Chimonides, P.J. \& Zhadan, D.G. 2000. Semper's (zoanthid) larvae: pelagic life, parentage and other problems. Hydrobiologia 440, 191-198.

Sala, O.E., Stuart Chapin , F., III, Armesto, J.J., Berlow, E., Bloomfield, J., Dirzo, R., Huber-Sanwald, E., Huenneke, L.F., Jackson, R.B., Kinzig, A., Leemans, R., Lodge, D.M., Mooney, H.A., Oesterheld, M.n., Poff, N.L., Sykes, M.T., Walker, B.H., Walker, M. \& Wall, D.H. 2000. Global biodiversity scenarios for the year 2100. Science 287, 1770-1774.

Salman, A., Lombardo, S. \& Doody, P. 2004. Living with coastal erosion in Europe: sediment and space for sustainability. EUCC: Rijkswaterstaat.

Salmon, A., Ainouche, M.L. \& Wendel, J.F. 2005. Genetic and epigenetic consequences of recent hybridization and polyploidy in Spartina (Poaceae). Molecular Ecology 14, 1163-1175.

Salomidi, M., Katsanevakis, S., Issaris, Y., Tsiamis, K. \& Katsiaras, N. 2013. Anthropogenic disturbance of coastal habitats promotes the spread of the introduced scleractinian coral Oculina patagonica in the Mediterranean Sea. Biological Invasions 15, 1961-1971.

Sammarco, P.W., Atchison, A.D. \& Boland, G.S. 2004. Expansion of coral communities within the Northern Gulf of Mexico via offshore oil and gas platforms. Marine Ecology Progress Series 280, 129-143.

Sammarco, P.W., Brazeau, D.A. \& Sinclair, J. 2012. Genetic connectivity in scleractinian corals across the Northern Gulf of Mexico: oil/gas platforms, and relationship to the Flower Garden Banks. PLoS ONE 7, e30144.

Sammarco, P.W., Lirette, A., Tung, Y.F., Boland, G.S., Genazzio, M. \& Sinclair, J. 2014. Coral communities on artificial reefs in the Gulf of Mexico: standing vs. toppled oil platforms. ICES Journal of Marine Science 71, 417-426.

Sammarco, P.W., Porter, S.A. \& Cairns, S.D. 2010. A new coral species introduced into the Atlantic OceanTubastraea micranthus (Ehrenberg 1834) (Cnidaria, Anthozoa, Scleractinia): an invasive threat? Aquatic Invasions 5, 131-140.

Saura, S., Bodin, O., Fortin, M.-J. \& Frair, J. 2013. Stepping stones are crucial for species' long-distance dispersal and range expansion through habitat networks. Journal of Applied Ecology 51, 171-182. 


\section{LOUISE B. FIRTH ET AL.}

Sayer, M.D.J. \& Baine, M.S.P. 2002. Rigs to Reefs: a critical evaluation of the potential for reef development using decommissioned rigs. Underwater Technology 25, 93-98.

Sayers, P., Walsh, C. \& Dawson, R. 2015. Climate impacts on flood and coastal erosion infrastructure. Infrastructure Asset Management, 2, 69-83.

Scyphers, S., Powers, S. \& Heck, K., Jr. 2015. Ecological value of submerged breakwaters for habitat enhancement on a residential scale. Environmental Management 55, 383-391.

Scyphers, S.B., Powers, S.P., Heck, K.L., Jr. \& Byron, D. 2011. Oyster reefs as natural breakwaters mitigate shoreline loss and facilitate fisheries. PLOS ONE 6, e22396.

Searle, J.B., Kotlík, P., Rambau, R.V., Marková, S., Herman, J.S. \& McDevitt, A.D. 2009. The Celtic fringe of Britain: insights from small mammal phylogeography. Proceedings of the Royal Society B: Biological Sciences 276, 4287-4294.

Seto, K.C., Fragkias, M., Güneralp, B. \& Reilly, M.K. 2011. A meta-analysis of global urban land expansion. PLOS ONE 6, e23777.

Shanks, A.L. 2009. Pelagic larval duration and dispersal distance revisited. The Biological Bulletin 216, 373-385.

Shanks, A.L., Grantham, B.A. \& Carr, M.H. 2003. Propagule dispersal distance and the size and spacing of marine reserves. Ecological Applications 13, S159-S169.

Sheehan, E.V., Attrill, M.J., Thompson, R.C. \& Coleman, R.A. 2012. Changes in shorebird behaviour and distribution associated with an intertidal crab fishery. Aquatic Conservation: Marine and Freshwater Ecosystems 22, 683-694.

Sheehan, E.V., Coleman, R.A., Attrill, M.J. \& Thompson, R.C. 2010a. A quantitative assessment of the response of mobile estuarine fauna to crab-tiles during tidal immersion using remote underwater video cameras. Journal of Experimental Marine Biology and Ecology 387, 68-74.

Sheehan, E.V., Coleman, R.A., Thompson, R.C. \& Attrill, M.J. 2010b. Crab-tiling reduces the diversity of estuarine infauna. Marine Ecology Progress Series 411, 137-148.

Sheehan, E.V., Gall, S.C., Cousens, S.L. \& Attrill, M.J. 2013. Epibenthic assessment of a renewable tidal energy site. The Scientific World Journal 906180, 8 only.

Sheehan, E.V., Thompson, R.C., Coleman, R.A. \& Attrill, M.J. 2008. Positive feedback fishery: population consequences of 'crab-tiling' on the green crab Carcinus maenas. Journal of Sea Research 60, 303-309.

Sheehy, D.J. \& Vik, S.F. 2010. The role of constructed reefs in non-indigenous species introductions and range expansions. Ecological Engineering 36, 1-11.

Shepard, C.C., Crain, C.M. \& Beck, M.W. 2011. The protective role of coastal marshes: a systematic review and meta-analysis. PLOS ONE 6, e27374.

Sheppard, C.R.C. \& Salm, R.V. 1988. Reef and coral communities of Oman, with a description of a new coral species (Order Scleractinia, genus Acanthastrea). Journal of Natural History 22, 263-279.

Sheppard, S.R. 2012. Visualizing Climate Change: a Guide to Visual Communication of Climate Change and Developing Local Solutions. London: Routledge.

Short, A.D. \& Hesp, P.A. 1982. Wave, beach and dune interactions in southeastern Australia. Marine Geology 48, 259-284.

Short, F., Carruthers, T., Dennison, W. \& Waycott, M. 2007. Global seagrass distribution and diversity: a bioregional model. Journal of Experimental Marine Biology and Ecology 350, 3-20.

Siegel, D.A., Kinlan, B.P., Gaylord, B. \& Gaines, S.D. 2003. Lagrangian descriptions of marine larval dispersion. Marine Ecology Progress Series 260, 83-96.

Silliman, B.R., Grosholz, E. \& Bertness, M.D. 2009. Human Impacts on Salt Marshes: A Global Perspective. Oakland, California: University of California Press.

Simkanin, C., Dower, J.F., Filip, N., Jamieson, G. \& Therriault, T.W. 2013. Biotic resistance to the infiltration of natural benthic habitats: examining the role of predation in the distribution of the invasive ascidian Botrylloides violaceus. Journal of Experimental Marine Biology and Ecology 439, 76-83.

Simkanin, C., Power, A.M., Myers, A., McGrath, D., Southward, A., Mieszkowska, N., Leaper, R. \& O’Riordan, R. 2005. Using historical data to detect temporal changes in the abundances of intertidal species on Irish shores. Journal of the Marine Biological Association of the United Kingdom 85, 1329-1340.

Smale, D.A., Burrows, M.T., Moore, P., O’Connor, N. \& Hawkins, S.J. 2013. Threats and knowledge gaps for ecosystem services provided by kelp forests: a northeast Atlantic perspective. Ecology and Evolution 3, 4016-4038. 


\section{OCEAN SPRAWL}

Smale, D.A. \& Vance, T. 2015. Climate-driven shifts in species' distributions may exacerbate the impacts of storm disturbances on North-east Atlantic kelp forests. Marine and Freshwater Research 67, 65-74.

Smale, D.A., Wernberg, T., Yunnie, A.L.E. \& Vance, T. 2014. The rise of Laminaria ochroleuca in the Western English Channel (UK) and comparisons with its competitor and assemblage dominant Laminaria hyperborea. Marine Ecology 36, 1033-1044.

Small, C. \& Nicholls, R.J. 2003. A global analysis of human settlement in coastal zones. Journal of Coastal Research 19, 584-599.

Smith, K. 2011. We are seven billion. Nature Climate Change 1, 331-335.

Smyth, K., Christie, N., Burdon, D., Atkins, J.P., Barnes, R. \& Elliott, M. 2015. Renewables-to-reefs?Decommissioning options for the offshore wind power industry. Marine Pollution Bulletin 90, 247-258.

Sorte, C.J.B., Williams, S.L. \& Carlton, J.T. 2010. Marine range shifts and species introductions: comparative spread rates and community impacts. Global Ecology and Biogeography 19, 303-316.

Southward, A.J. 1995. Occurrence in the English Channel of a warm-water Cirripede, Solidobalanus fallax. Journal of the Marine Biological Association of the United Kingdom 75, 199-210.

Southward, A.J. \& Orton, J.H. 1954. The effects of wave-action on the distribution and numbers of the commoner plants and animals living on the Plymouth breakwater. Journal of the Marine Biological Association of the United Kingdom 33, 1-19.

Spalding, M. 2010. World Atlas of Mangroves. London: Routledge.

Spalding, M.D., Ruffo, S., Lacambra, C., Meliane, I., Hale, L.Z., Shepard, C.C. \& Beck, M.W. 2014. The role of ecosystems in coastal protection: adapting to climate change and coastal hazards. Ocean \& Coastal Management 90, 50-57.

Spanier, E., Lavalli, K.L. \& Edelist, D. 2011. Artificial reefs for lobsters: an overview of their application for fisheries enhancement, management, and conservation. In Artificial Reefs in Fisheries Management, S.A. Bortone et al. (eds); Boca Raton, Florida, 77-110.

Spinuzzi, S., Schneider, K.R., Walters, L.J., Yuan, W.S. \& Hoffman, E.A. 2013. Tracking the distribution of non-native marine invertebrates (Mytella charruana, Perna viridis and Megabalanus coccopoma) along the south-eastern USA. Marine Biodiversity Records 6, e55 only.

Stachowicz, J.J., Fried, H., Osman, R.W. \& Whitlatch, R.B. 2002a. Biodiversity, invasion resistance, and marine ecosystem function: reconciling pattern and process. Ecology 83, 2575-2590.

Stachowicz, J.J., Terwin, J.R., Whitlatch, R.B. \& Osman, R.W. 2002b. Linking climate change and biological invasions: ocean warming facilitates nonindigenous species invasions. Proceedings of the National Academy of Sciences of the United States of America 99, 15497-15500.

Stachowicz, J.J., Whitlatch, R.B. \& Osman, R.W. 1999. Species diversity and invasion resistance in a marine ecosystem. Science 286, 1577-1579.

Stancheva, M., Rangel-Buitrago, N., Anfuso, G., Palazov, A., Stanchev, H. \& Correa, I. 2011. Expanding level of coastal armouring: case studies from different countries. Journal of Coastal Research SI 64, 0749-0208.

Stanley, D.R. \& Wilson, D.R. 1997. Seasonal and spatial variation in abundance and size distribution of fishes associated with a petroleum platform. Journal of Marine Science 202, 473-475

Steneck, R.S., Graham, M.H., Bourque, B.J., Corbett, D., Erlandson, J.M., Estes, J.A. \& Tegner, M.J. 2002. Kelp forest ecosystems: biodiversity, stability, resilience and future. Environmental Conservation 29, 436-459.

Stive, M.J.F., de Schipper, M.A., Luijendijk, A.P., Aarninkhof, S.G.J., van Gelder-Maas, C., de Vries, J.S.M.V., de Vries, S., Henriquez, M., Marx, S. \& Ranasinghe, R. 2013. A new alternative to saving our beaches from sea-level rise: the sand engine. Journal of Coastal Research 29, 1001-1008.

Stolk, P., Markwell, K. \& Jenkins, J.M. 2007. Artificial reefs as recreational scuba diving resources: a critical review of research. Journal of Sustainable Tourism 15, 331-350.

Strain, E.M.A., Allcock, A.L., Goodwin, C.E., Maggs, C.A., Picton, B.E. \& Roberts, D. 2012. The long-term impacts of fisheries on epifaunal assemblage function and structure in a Special Area of Conservation. Journal of Sea Research 67, 58-68.

Stratigaki, V., Manca, E., Prinos, P., Losada, I.J., Lara, J.L., Sclavo, M., Amos, C.L., Cáceres, I. \& SánchezArcilla, A. 2011. Large-scale experiments on wave propagation over Posidonia oceanica. Journal of Hydraulic Research 49, 31-43. 


\section{LOUISE B. FIRTH ET AL.}

Streftaris, N., Zenetos, A. \& Papathanassiou, E. 2005. Globalisation in marine ecosystems: the story of nonindigenous marine species across European seas. Oceanography and Marine Biology: an Annual Review 43, 419-453.

Strong, D.R. \& Ayres, D.A. 2009. Spartina introductions and consequences in salt marshes. In Human Impacts on Salt Marshes: A Global Perspective, B.R. Silliman et al.(eds). Oakland, California: University of California Press, 3-22.

Sunday, J.M., Bates, A.E. \& Dulvy, N.K. 2012. Thermal tolerance and the global redistribution of animals. Nature Climate Change 2, 686-690.

Susini, M.L., Mangialajo, L., Thibaut, T. \& Meinesz, A. 2007. Development of a transplantation technique of Cystoseira amentacea var. stricta and Cystoseira compressa. In Biodiversity in Enclosed Seas and Artificial Marine Habitats, G. Relini \& J.S. Ryland (eds). Dordrecht, the Netherlands: Springer, 241-244.

Sutton-Grier, A.E., Wowk, K. \& Bamford, H. 2015. Future of our coasts: the potential for natural and hybrid infrastructure to enhance the resilience of our coastal communities, economies and ecosystems. Environmental Science \& Policy 51, 137-148.

Swearer, S.E., Caselle, J.E., Lea, D.W. \& Warner, R.R. 1999. Larval retention and recruitment in an island population of a coral reef fish. Nature 402, 799-802.

Tam, N.F.Y., Wong, Y.S., Lan, C.Y. \& Chen, G.Z. 1995. Community structure and standing crop biomass of a mangrove forest in Futian Nature Reserve, Shenzhen, China. Hydrobiologia 295, 193-201.

Tamin, N.M., Zakaria, R., Hashim, R. \& Yin, Y. 2011. Establishment of Avicennia marina mangroves on accreting coastline at Sungai Haji Dorani, Selangor, Malaysia. Estuarine, Coastal and Shelf Science 94, 334-342.

Tebboth, M. 2014. Understanding intractable environmental policy conflicts: the case of the village that would not fall quietly into the sea. The Geographical Journal 180, 224-235.

Temmerman, S., Meire, P., Bouma, T.J., Herman, P.M.J., Ysebaert, T. \& De Vriend, H.J. 2013. Ecosystembased coastal defence in the face of global change. Nature 504, 79-83.

Thomas, C.D. 2011. Translocation of species, climate change, and the end of trying to recreate past ecological communities. Trends in Ecology \& Evolution 26, 216-221.

Thompson, R.C., Crowe, T.P. \& Hawkins, S.J. 2002. Rocky intertidal communities: past environmental changes, present status and predictions for the next 25 years. Environmental Conservation 29, 168-191.

Thorson, G. 1946. Reproduction and larval development of Danish bottom invertebrates, with special reference to the planktonic larvae in the Sound (Øresund). Meddelelser fra Kommissionen for Danmarks Fiskeri -og Havundersøgelser, Ser. Plankton. 4.

Thorson, G. 1950. Reproductive and larval ecology of marine bottom invertebrates. Biological Reviews 25, $1-45$.

Thuiller, W. 2004. Patterns and uncertainties of species' range shifts under climate change. Global Change Biology 10, 2020-2027.

Toft, J.D., Cordell, J.R., Simenstad, C.A. \& Stamatiou, L.A. 2007. Fish distribution, abundance, and behavior along city shoreline types in Puget Sound. North American Journal of Fisheries Management 27, $465-480$.

Toft, J.D., Ogston, A., Heerhartz, S.D., Cordell, J.R., Armbrust, E.A. \& Levy, C. 2010. Olympic Sculpture Park: Year 3 monitoring of shoreline enhancements. Report prepared for Seattle Public Utilities, City of Seattle, SAFS-UW-1002.

Toft, J.D., Ogston, A.S., Heerhartz, S.M., Cordell, J.R. \& Flemer, E.E. 2013. Ecological response and physical stability of habitat enhancements along an urban armored shoreline. Ecological Engineering 57, 97-108.

Tomanek, L. \& Somero, G.N. 1999. Evolutionary and acclimation-induced variation in the heat-shock responses of congeneric marine snails (genus Tegula) from different thermal habitats: implications for limits of thermotolerance and biogeography. Journal of Experimental Biology 202, 2925-2936.

Trakhtenbrot, A., Nathan, R., Perry, G. \& Richardson, D.M. 2005. The importance of long-distance dispersal in biodiversity conservation. Diversity and Distributions 11, 173-181.

Türker, U., Yagci, O. \& Kabdaşl1, M.S. 2006. Analysis of coastal damage of a beach profile under the protection of emergent vegetation. Ocean Engineering 33, 810-828.

Turner, R.K., Burgess, D., Hadley, D., Coombes, E. \& Jackson, N. 2007. A cost-benefit appraisal of coastal managed realignment policy. Global Environmental Change-Human and Policy Dimensions 17, 397-407. 


\section{OCEAN SPRAWL}

Tyrrell, M.C. \& Byers, J.E. 2007. Do artificial substrates favor non-indigenous fouling species over native species? Journal of Experimental Marine Biology and Ecology 342, 54-60.

Tyrrell, M.C., Thornber, C.S., Burkhardt, J.A. \& Congretel, M. 2015. The influence of salt marsh fucoid algae (Ecads) on sediment dynamics of northwest Atlantic Marshes. Estuaries and Coasts 38, 1262-1273.

United Nations Environment Programme, Department of Economic and Social Affairs, Population Division (UNEP DESAP). 2014. World Urbanisation Prospects: The 2014 Revision, Highlights (ST/ESA/ SER.A/352). New York: United Nations, Department of Economic and Social Affairs, Population Division.

Urian, A.G., Hatle, J.D. \& Gilg, M.R. 2011. Thermal constraints for range expansion of the invasive green mussel, Perna viridis, in the southeastern United States. Journal of Experimental Zoology Part A: Ecological Genetics and Physiology 315A, 12-21.

Valiela, I., Bowen, J.L. \& York, J.K. 2001. Mangrove forests: one of the world's threatened major tropical environments. BioScience 51, 807-815.

van der Meulen, F., van der Valk, B., Baars, L., Schoor, E. \& van Woerden, H. 2014. Development of new dunes in the Dutch Delta: nature compensation and 'building with nature'. Journal of Coastal Conservation 18, 505-513.

van Loon-Steensma, J.M.V. \& Slim, P.A. 2013. The impact of erosion protection by stone dams on salt-marsh vegetation on two Wadden Sea barrier islands. Journal of Coastal Research 44, 783-796.

van Vuuren, D. \& Riahi, K. 2011. The relationship between short-term emissions and long-term concentration targets. Climatic Change 104, 793-801.

Vaselli, S., Bulleri, F. \& Benedetti-Cecchi, L. 2008. Hard coastal-defence structures as habitats for native and exotic rocky-bottom species. Marine Environmental Research 66, 395-403.

Velegrinis, S. \& Katodrytis, G. 2015. Drawing on sand: cities in the making. Architectural Design 85, 72-79.

Vila, M., Garcés, E., Masó, M. \& Camp, J. 2001. Is the distribution of the toxic dinoflagellate Alexandrium catenella expanding along the NW Mediterranean coast? Marine Ecology Progress Series 222, 73-83.

Villareal, T.A., Hanson, S., Qualia, S., Jester, E.L.E., Granade, H.R. \& Dickey, R.W. 2007. Petroleum production platforms as sites for the expansion of ciguatera in the northwestern Gulf of Mexico. Harmful Algae 6, 253-259.

Vitousek, P.M., D’Antonio, C.M., Loope, L.L., Rejmánek, M. \& Westbrooks, R. 1997. Introduced species: a significant component of human-caused global change. New Zealand Journal of Ecology 21, 1-16.

Wahl, M. 1989. Marine epibiosis. I. Fouling and antifouling: some basic aspects. Marine Ecology Progress Series 58, 175-189.

Wang, Q., An, S., Ma, Z., Zhao, B., Chen, J. \& Li, B. 2006. Invasive Spartina alterniflora: biology, ecology and management. Acta Phytotaxonomica Sinica 44, 559-588.

Waycott, M., Duarte, C.M., Carruthers, T.J.B., Orth, R.J., Dennison, W.C., Olyarnik, S., Calladine, A., Fourqurean, J.W., Heck, K.L., Hughes, A.R., Kendrick, G.A., Kenworthy, W.J., Short, F.T. \& Williams, S.L. 2009. Accelerating loss of seagrasses across the globe threatens coastal ecosystems. Proceedings of the National Academy of Sciences of the United States of America 106, 12377-12381.

Wehkamp, S. \& Fischer, P. 2013. Impact of coastal defence structures (tetrapods) on a demersal hard-bottom fish community in the southern North Sea. Marine Environmental Research 83, 82-92.

Wendt, P.H., Knott, D.M. \& Van Dolah, R.F. 1989. Community structure of the sessile biota on five artificial reefs of different ages. Bulletin of Marine Science 44, 1106-1122.

Wernberg, T., Russell, B.D., Moore, P.J., Ling, S.D., Smale, D.A., Campbell, A., Coleman, M.A., Steinberg, P.D., Kendrick, G.A. \& Connell, S.D. 2011. Impacts of climate change in a global hotspot for temperate marine biodiversity and ocean warming. Journal of Experimental Marine Biology and Ecology 400, $7-16$.

Wernberg, T., Smale, D.A., Tuya, F., Thomsen, M.S., Langlois, T.J., de Bettignies, T., Bennett, S. \& Rousseaux, C.S. 2013. An extreme climatic event alters marine ecosystem structure in a global biodiversity hotspot. Nature Climate Change 3, 78-82.

Westwood, A. 2004. Ocean power: Wave and tidal energy review. Refocus 5, 50-55.

Wethey, D.S., Woodin, S.A., Hilbish, T.J., Jones, S.J., Lima, F.P. \& Brannock, P.M. 2011. Response of intertidal populations to climate: effects of extreme events versus long term change. Journal of Experimental Marine Biology and Ecology 400, 132-144.

Whelan, A. \& Regan, F. 2006. Antifouling strategies for marine and riverine sensors. Journal of Environmental Monitoring 8, 880-886. 


\section{LOUISE B. FIRTH ET AL.}

Wiedemann, A.M. \& Pickart, A. 1996. The Ammophila problem on the Northwest coast of North America. Landscape and Urban Planning 34, 287-299.

Wilding, T.A. 2014. Effects of man-made structures on sedimentary oxygenation: extent, seasonality and implications for offshore renewables. Marine Environmental Research 97, 39-47.

Wilding, T.A. \& Sayer, M.D.J. 2002. Evaluating artificial reef performance: approaches to pre- and postdeployment research. ICES Journal of Marine Science 59, S222-S230.

Wilhelmsson, D. \& Malm, T. 2008. Fouling assemblages on offshore wind power plants and adjacent substrata. Estuarine, Coastal and Shelf Science 79, 459-466.

Wilhelmsson, D., Malm, T. \& Öhman, M.C. 2006. The influence of offshore windpower on demersal fish. ICES Journal of Marine Science 63, 775-784.

Wilhelmsson, D., Malm, T., Thompson, R., Tchou, J., Sarantakos, G., McCormick, N., Luitjens, S., Gullström, M., Patterson Edwards, J.K., Amir, O. \& Dubi, A. 2010. Greening Blue Energy: Identifying and Managing the Biodiversity Risks and Opportunities of Off Shore Renewable Energy. Gland, Switzerland: IUCN.

Wilhelmsson, D., Öhman, M.C., Ståhl, H. \& Shlesinger, Y. 1998. Artificial reefs and dive tourism in Eilat, Israel. Ambio 27, 764-766.

Wilkinson, S.B., Zheng, W., Allen, J.R., Fielding, N.J., Wanstall, V.C., Russell, G. \& Hawkins, S.J. 1996. Water quality improvements in Liverpool Docks: the role of filter feeders in algal and nutrient dynamics. Marine Ecology 17, 197-211.

Williams, A. \& Feagin, R. 2010. Sargassum as a natural solution to enhance dune plant growth. Environmental Management 46, 738-747.

Wilson, A.M.W., Mugerauer, R. \& Klinger, T. 2015. Rethinking marine infrastructure policy and practice: Insights from three large-scale marina developments in Seattle. Marine Policy 53, 67-82.

Wilson, J.C. \& Elliott, M. 2009. The habitat-creation potential of offshore wind farms. Wind Energy 12, 203-212.

Witt, M.J., Sheehan, E.V., Bearhop, S., Broderick, A.C., Conley, D.C., Cotterell, S.P., Crow, E., Grecian, W.J., Halsband, C., Hodgson, D.J., Hosegood, P., Inger, R., Miller, P.I., Sims, D.W., Thompson, R.C., Vanstaen, K., Votier, S.C., Attrill, M.J. \& Godley, B.J. 2012. Assessing wave energy effects on biodiversity: the Wave Hub experience. Philosophical Transactions of the Royal Society A: Mathematical, Physical and Engineering Sciences 370, 502-529.

Wolters, M., Bakker, J.P., Bertness, M.D., Jefferies, R.L. \& Móller, I. 2005. Saltmarsh erosion and restoration in south-east England: squeezing the evidence requires realignment. Journal of Applied Ecology $\mathbf{4 2}$, $844-851$.

Woodin, S.A., Wethey, D.S. \& Dubois, S.F. 2014. Population structure and spread of the polychaete Diopatra biscayensis along the French Atlantic coast: human-assisted transport by-passes larval dispersal. Marine Environmental Research 102, 110-121.

Wyles, K.J., Pahl, S., Thomas, K. \& Thompson, R.C. 2015. Factors that can undermine the psychological benefits of coastal environments: exploring the effect of tidal state, presence, and type of litter. Environment and Behavior July 2015, doi:10.1177/0013916515592177

Wyles, K.J., Pahl, S. \& Thompson, R.C. 2014. Perceived risks and benefits of recreational visits to the marine environment: integrating impacts on the environment and impacts on the visitor. Ocean \& Coastal Management 88, 53-63.

Yang, F., Zhang, X., Chen, S. \& Wang, Z. 2015. The development and operation of offshore wind farms in China. In 2015 Asia-Pacific Energy Equipment Engineering Research Conference. Bedford Park, Illinois: Atlantic Press.

Yang, S.L., Shi, B.W., Bouma, T.J., Ysebaert, T. \& Luo, X.X. 2012. Wave attenuation at a salt marsh margin: a case study of an exposed coast on the Yangtze Estuary. Estuaries and Coasts 35, 169-182.

Yeo, D.C.J., Ahyong, S.T., Lodge, D.M., Ng, P.K.L., Naruse, T. \& Lane, D.J.W. 2010. Semisubmersible oil platforms: understudied and potentially major vectors of biofouling-mediated invasions. Biofouling 26, 179-186.

Yesson, C., Bush, L.E., Davies, A.J., Maggs, C.A. \& Brodie, J. 2015. Large brown seaweeds of the British Isles: evidence of changes in abundance over four decades. Estuarine, Coastal and Shelf Science 155, 167-175.

Ysebaert, T., Yang, S.-L., Zhang, L., He, Q., Bouma, T. \& Herman, P.J. 2011. Wave attenuation by two contrasting ecosystem engineering salt marsh macrophytes in the intertidal pioneer zone. Wetlands 31, 1043-1054. 


\section{OCEAN SPRAWL}

Zacherl, D., Gaines, S.D. \& Lonhart, S.I. 2003. The limits to biogeographical distributions: insights from the northward range extension of the marine snail, Kelletia kelletii (Forbes, 1852). Journal of Biogeography 30, 913-924.

Zanuttigh, B., Angelelli, E., Bellotti, G., Romano, A., Krontira, Y., Troianos, D., Suffredini, R., Francheschi, G., Cantu, M., Airoldi, L., Zagonari, F., Taramelli, A., Filipponi, F., Jimenez, C., Evriadou, M. \& Broszeit, S. 2015. Boosting blue growth in a mild sea: analysis of the synergies produced by a multipurpose offshore installation in the Northern Adriatic, Italy. Sustainability 7, 6804-6853.

Zanuttigh, B., Nicholls, R.J., Vanderlinden, J.-P., Burcharth, H.F. \& Thompson, R.C. 2014. Coastal Risk Management in a Changing Climate. Oxford, UK: Butterworth-Heinemann. 
